\title{
CITY OF WATSONVILLE \\ LOCAL HAZARD MITIGATION PLAN
}

\author{
A Professional Project \\ presented to \\ the Faculty of California Polytechnic State University, \\ San Luis Obispo
}

\author{
In Partial Fulfillment \\ of the Requirements for the Degree \\ Master of City and Regional Planning \\ by
}

Emily Margaret Lipoma

June 2012 
(C) 2012

Emily Margaret Lipoma

ALL RIGHTS RESER VED 


\section{COMMITTEE MEMBERSHIP}

TITLE:

AUTHOR:

DATE SUBMITTED:

COMMITTEE CHAIR:

COMMITTEE MEMBER: $\quad$ Kenneth Topping, FAICP, Lecturer

COMMITTEE MEMBER: Corinne Bartshire, AICP, CFM, Project Manager
Emily Margaret Lipoma

June 2012 


\section{ABSTRACT \\ City of Watsonville Local Hazard Mitigation Plan \\ Emily Margaret Lipoma}

The City of Watsonville is vulnerable to a number of natural and man-made hazards. This project analyzed this risk and vulnerabilities to critical facilities within the city, and made recommendations of mitigation strategies and implementation methods to address this risk. Analysis and data collection was conducted in coordination with the City of Watsonville Fire Department and the resulting product will be given to the City for their use and potential adoption. The documents within this Local Hazard Mitigation Plan was developed to the standards and specifications developed by the State of California and Federal Emergency Management Agency for a Local Hazard Mitigation Plan in order for the opportunity for the City of Watsonville to be able to use the information contained here to develop a State and Federallyapproved Local Hazard Mitigation Plan.

The hazards analyzed within this document are as follows: earthquakes, wildfires, urban and industrial fires, flooding, hazardous materials, liquefaction, land subsidence, landslides, unreinforced masonry, airport hazards, civil disturbance/terrorism, dam failure, drought, expansive soils, natural gas pipeline failure, vehicle collisions, tornados, and tsunamis. 


\section{TABLE OF CONTENTS}

$\begin{array}{lr}\text { 1.0 Community Profile } & 1\end{array}$

1.1 Population and Demographics 3

$\begin{array}{ll}1.2 \text { Economic Trends } & 6\end{array}$

1.3 Community Vision $\quad 7$

1.4 Land Use Patterns 9

1.5 History of Hazardous Events 10

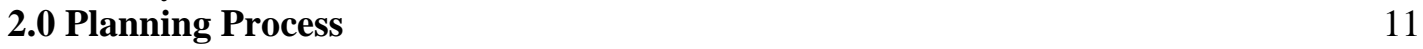

2.1 The Planning Process 11

2.2 Community Participation $\quad 12$

3.0 Risk and Vulnerability Assessment 13

3.1 Critical Facilities 14

3.2 Hazard Assessment and Prioritization 19

3.3 Earthquake 21

3.4 Fire 30

3.5 Flood 35

3.6 Hazardous Materials $\quad 49$

3.7 Liquefaction 53

3.8 Land Subsidence $\quad 58$

3.9 Landslides $\quad 60$

3.10 Unreinforced Masonry 64

3.11 Airport Hazards 68

3.12 Civil Disturbance/Terrorism $\quad 74$

3.13 Dam Failure $\quad 76$

3.14 Drought $\quad 80$

3.15 Expansive Soils 85

3.16 Natural Gas Pipeline Failure $\quad 89$

$\begin{array}{ll}3.17 \text { Vehicle Collision } & 94\end{array}$

3.18 Tornado 95

3.19 Tsunami 97

3.20 Hazards That Do Not Present a Risk to the City 100

3.21 Multi-Hazard Summary 103

4.0 Capability Assessment 105

4.1 Staff and Organizational Capability: Departmental Responsibilities 105

4.2 Technical Capability 108

4.3 Policy and Program Capability 108

4.4 Summary of Relevant Ordinances 119

$\begin{array}{lr}4.5 \text { Federal Programs } & 119\end{array}$

$\begin{array}{ll}\text { 5.0 Mitigation Strategy } & 122\end{array}$

5.1 Goals 126

$\begin{array}{ll}5.2 \text { Objectives } & 127\end{array}$

5.3 Identification of Actions 128

5.4 Developing an Implementation Strategy 137 


\section{LIST OF TABLES}

Table 1.1-1 City of Watsonville Demographics $\quad 4$

Table 1.1-2 City of Watsonville Population Change $\quad 5$

Table 2.1-1 Planning Meetings $\quad 12$

Table 3.1-1 City Operation Facilities

Table 3.1-2 Primary Red Cross Shelters 16

Table 3.1-3 Critical City Infrastructure 16

$\begin{array}{ll}\text { Table 3.1-4 Special Population Centers } & 17\end{array}$

Table 3.1-5 Schools Within City Limits 18

$\begin{array}{ll}\text { Table 3.1-6 Historic Sites } & 19\end{array}$

Table 3.2-1 Hazard and Risk Associated for the City of Watsonville 20

Table 3.3-1 Previous Large Earthquakes in the Santa Cruz County Area 25

Table 3.3-2 Ten Most Likely Damaging Earthquake Scenarios in California 27

Table 3.5-1 Special Flood Hazard Areas $\quad 40$

Talbe 3.5-2 Drainage Areas for Corralitos Creek, Salsipuedes Creek, and Pajaro River 44

Table 3.6-1 Previous Events of Chemical Material Releases, 2002-2012 51

Table 3.10-1 Locations of Unreinforced Masonry Structures $\quad 67$

Table 3.11-1 Previous Aircraft Collision Incidents (Since 1982) 70

Table 3.13-1 Dams in the Proximity of the City of Watsonville $\quad 77$

Table 3.14-1 City of Watsonville Water Sources $\quad 82$

Table 3.16-1 Number of Critical Facilities Within 1000 Ft of a Natural Gas Transmission Pipeline 93 
Table 3.18-1 Previous Occurrences of Tornados in Santa Cruz County

Table 4.2-1 Technical Capability Matrix

Table 4.3-1 Available Plans and Ordinances

108

Table 4.3-2 Projects Addressing Flood Control in the City of Watsonville

113

Table 4.3-3 Plans Associated With the Integrated Regional Water Management Plan

113 


\section{LIST OF FIGURES}

$\begin{array}{ll}\text { Figure 1.0-1Regional Area } & 1\end{array}$

Figure 1.0-2 Watsonville City Boundaries and Service Areas 3

$\begin{array}{ll}\text { Figure 3.3-1 Earthquake Fault Lines } & 23\end{array}$

Figure 3.4-1 Fire Hazard Severity Zones $\quad 31$

Figure 3.5-1 Areas of Flood Hazard $\quad 37$

$\begin{array}{ll}\text { Figure 3.5-2 Flood Areas and Daycare Facilities } & 47\end{array}$

$\begin{array}{ll}\text { Figure 3.5-3 Flood Areas and Historic Properties } & 48\end{array}$

Figure 3.7-1 Liquefaction Areas $\quad 54$

$\begin{array}{ll}\text { Figure 3.9-1 Sloped Soils } & 61\end{array}$

$\begin{array}{ll}\text { Figure 3.15-1 Expansive Soils } & 86\end{array}$

Figure 3.16-1 Approximate PG\&E Natural Gas Transmission Pipeline Location 91 


\subsection{Community Profile}

The City of Watsonville is located in the Pajaro Valley, in south Santa Cruz County. Although the county is coastal the City of Watsonville is located inland with only a small portion of the city within the Coastal Zone. The valley is a fertile agricultural area and much of the city's economic activity is associated with adjacent agricultural activities. Watsonville is relatively level, although the surrounding area has some hills. Bodies of water, waterways and wetlands make up prominent features of the city; Corralitos Creek and Salsipuedes Creek form the northerly and easterly boundary of Watsonville while the Pajaro River forms the easterly and southerly boundary of the City. Struve Slough, Watsonville Slough and Harkins Slough are small streams which originate with the City and create an extensive wetland system in the southerly portion of the city and further south in the county. This system is supplemented by five small lakes near the city, one of which, Pinto Lake, is a non-contiguous city park in the city. Other noncontiguous areas of the city include the Wastewater Treatment Plant south of the city on the Pajaro River, Buena Vista Landfill to the north west of the city, the Corralitos Water Treatment Plant to the north of the city. The Grizzly Flatsarea to the north of the city is also a non-contiguous city area; it is uninhabited acreage used for watershed management.

\section{Figure 1.0-1 Regional Area}

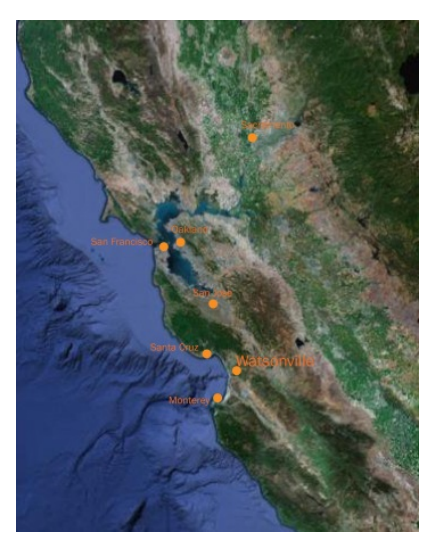


The Watsonville area was initially cultivated as cattle pasture land for the Spanish Missions in the area and many settlers were drawn to the city in the mid 1800's for agriculture opportunities. Watsonville was incorporated in 1869 and is now approximately 6.6 square miles with over 50,000 residents. The rich agriculture economy continues to the present day and recognizes the strong history of agriculture in the area. (City of Watsonville, 2006)

Watsonville has a Mediterranean climate characterized by warm, dry, summers and mild, rainy winters. Warm temperatures and low precipitation are the norm from approximately April through October, and November through March is characterized by cooler temperatures and heavy rains. Winters are typically mild yet colder winds from inland regions with more continental climates can result in short-term cold snaps. The average temperature through the year is approximately 56 degrees with the average high temperature of 69 degrees Fahrenheit and the average low temperature of 44 degrees Fahrenheit. This temperate climate limits the threat of extreme heat and encourages agricultural growth. The summer and winter temperatures are moderated by the marine influence and summer fog is a common occurrence. The regular occurrence of fog has created hazardous flying conditions for the Watsonville airport in the past. Winds are generally northwesterly and seldom reach severe intensities. The Santa Cruz Mountains, to the east of Watsonville, form a natural barrier to winds from the north and from hot interior valleys. Rainfall is typically 22 inches per year in the Watsonville area. (County of Santa Cruz, 2010)

The City of Watsonville has three highways which connect the City with the rest of the County. Highway 1 is a prominent coastal highway and is along the southwest boarder of the city. Highways 129 and 152 connect the City to neighboring Santa Clara County to the east. The Santa Cruz Metropolitan Transit District (Metro) provides bus service throughout Santa Cruz County and into Santa Clara County. 
Figure 1.0-2 Watsonville City Boundaries and Service Areas

City of Watsonville

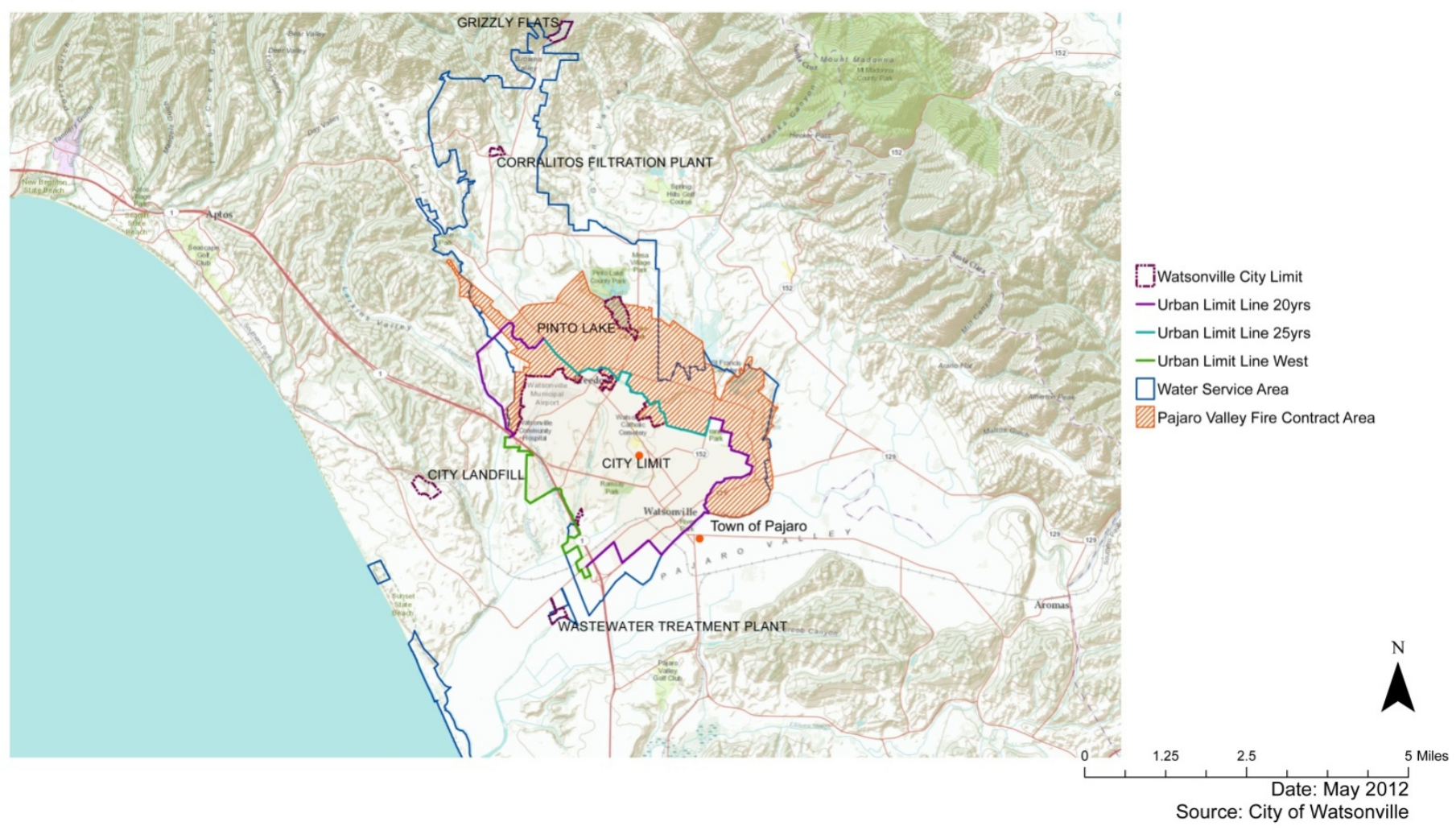

\subsection{Population and Demographics}

The City of Watsonville has experienced steady growth over past decades and currently has a population of 51,199. Growth in the city has been attributed to annexation of inhabited areas, new housing particularly suited for families, comparatively more affordable housing than other areas in the County, and an influx of agricultural workers or immigrants with connections to city residents. 
Table 1.1-1 City of Watsonville Demographics

\begin{tabular}{|c|c|c|}
\hline Population & Number & Percent \\
\hline Total Population & 51,199 & NA \\
\hline Percent Imputed** & & $23.1 \%$ \\
\hline \multicolumn{3}{|l|}{ Sex and Age } \\
\hline Male & 25,499 & $49.8 \%$ \\
\hline Female & 25,700 & $50.2 \%$ \\
\hline Median Age (years) & 29.2 & \\
\hline 18 years and under & 16,111 & $31.5 \%$ \\
\hline 65 years and older & 4,239 & $8.3 \%$ \\
\hline \multicolumn{3}{|l|}{ Income } \\
\hline Median household income* & $\$ 46,675$ & \\
\hline Persons below poverty* & $18.7 \%$ & \\
\hline \multicolumn{3}{|l|}{ Housing Characteristics } \\
\hline Total Housing Units & 14,089 & \\
\hline Vacant Housing Units & 561 & $4 \%$ \\
\hline Owner Occupied Housing Units & 5,957 & $44.0 \%$ \\
\hline $\begin{array}{l}\text { Population in Owner Occupied } \\
\text { Housing Units }\end{array}$ & 21,365 & \\
\hline $\begin{array}{l}\text { Average Household Size of Owner- } \\
\text { Occupied Units }\end{array}$ & 3.59 & \\
\hline Renter Occupied Housing Units & 7,571 & $56 \%$ \\
\hline $\begin{array}{l}\text { Population in Renter Occupied } \\
\text { Housing Units }\end{array}$ & 29,306 & \\
\hline $\begin{array}{l}\text { Average Household Size of Renter } \\
\text { Occupied Housing Units }\end{array}$ & 3.87 & \\
\hline $\begin{array}{l}\text { Housing Units in Multi-Unit } \\
\text { Structures* }\end{array}$ & $30.6 \%$ & \\
\hline
\end{tabular}
Source: 2010 Census

*2006-2010

**Disability status, hearing difficulty, vision difficulty, cognitive difficulty, ambulatory difficulty, selfcare difficulty, or independent living difficulty 


\section{Table 1.1-2 City of Watsonville Population Change}

\begin{tabular}{|l|l|l|}
\hline \multicolumn{1}{|c|}{ Year } & \multicolumn{1}{|c|}{ Population } & \multicolumn{1}{c|}{ Percent Change } \\
\hline 1980 & 23,662 & $31 \%$ \\
\hline 1990 & 31,099 & $49 \%$ \\
\hline 2000 & $46,468^{*}$ & $10 \%$ \\
\hline 2010 & 51,199 & \multicolumn{2}{|c|}{} \\
\hline
\end{tabular}

Source: 2010 Census, City of Watsonville General Plan

* The City’s 2000 Census population estimate was rectified in April 2003 from 44,265

The 2010 Census reported that most of the city's population identified themselves belonging to a particular race (category): 43.7\% White, 0.7\% Black or African American, 1.2\% American Indian or Alaska Native, and 3.3\% Asian. Asked about origin or ethnicity, $81.4 \%$ of the population considered themselves of Hispanic or Latino origin, an increase from 75\% of the population in 2000 and 60 percent in 1990. Of the total population, approximately $41.9 \%$ are foreign born with $93.2 \%$ of those born outside of the United States born in Latin America. With such a large percentage of the population born outside of the United States, it is not unexpected that only $26 \%$ of the population only speaks English in the home and that nearly $70 \%$ speak Spanish. Of the number of people that only speak Spanish in the home, $40 \%$ speak English less than "very well”. In the event of a disaster, communication can be critical and recognizing language barriers beforehand is crucial for emergency preparedness.

The City of Watsonville has a prominent youth population; 35.3\% of the population is under the age of 20,andthe median age of the population is 29.3 years. Because the city has a particularly young to middle aged population, a considerable increase in the number of middle-aged adults and seniors is anticipated in the next 10 to 20 years. While the population of the City is still anticipated to include a large segment of young people, this aging population will influence the City’s needs with long-term residents aging in place.

The household composition of the City has had dramatic impacts on the type of housing needed. The average household size has fluctuated over the past 30 years, from 3.24 persons per household in 1990, to 
3.84 in 2000, and 3.56 in 2010, but is still well over the state average of 2.89 persons per household. This trend has been partially explained by the high housing costs in the city and region coupled with the modest incomes of the city’s population. Many households are a “doubling up”, or multiple families living in one household, and may include extended family members.

Census figures report the median household income to be $\$ 46,675$ in 2010 . This reflects the number of residents holding lower-skilled, lower-paying jobs and who experience higher rates of unemployment in the City. In 2010 the unemployment rate was 7.4\%, compared to the countywide rate of 5.5\%. The education level of the City to the County is also considerably different: $52.5 \%$ percentage of the City population have a high school diploma, compared with $84.1 \%$ percent in the county. Similarly, 37.3\% percent of Santa Cruz County population have a bachelor's degree, while 10.2\% percent have the equivalent in Watsonville. However, over the past 10 years the median household income in Watsonville has increased, as has the percentage of people with high school diplomas and bachelor degrees while the percentage of people living below the poverty level has decreased(U.S. Census 2010a-f, City of Watsonville 2006).

\subsection{Economic Trends}

Given the city’s agricultural activities, it is no surprise that major employers in Watsonville are concentrated in associated industries such as food processing and distribution. Many of these companies chose Watsonville over other Bay Area locations because of cost considerations. Eventually, rising costs will begin to influence location and expansion decisions, even in lower-cost Watsonville. Moreover, interviews with local employers confirmed what the socioeconomic data suggest: educational attainment and workforce skills are a problem for employers and the lack of affordable housing is a problem for the 
employees. Complicating these issues are high unemployment rates (a common problem in seasonal agricultural economies) that are difficult to resolve without raising workforce skill levels. Meanwhile, many Santa Cruz County residents make a long, daily commute to jobs in other counties.

Over the past 10 years the city has met its goals in budget cycles through sound fiscal management and revenue growth through annexation. State and federal funds have also been successfully leveraged to support City activities. The State budget crisis threatens the stability of future state funding opportunities. State fiscal challenges, combined with the prospect of having fully developed the city's available land may present difficulties for the city to maintain current levels of service (City of Watsonville 2006).

\subsection{Community Vision}

The General Plan informs and guides the development of the City and the goals and policies set forth by the General Plan guide subsequent policy and program decisions by the City. The guiding principals of the General Plan, which reflect the community's desire for the future of the City, are listed below.

- Economic Development: Foster a prosperous and robust economy with policies that recognize the skills and needs of Watsonville’s workforce, while devising strategies that coordinate trends and the professional aspirations of Watsonville's youth with business development, business recruitment, education, and skill development programs. Policies and public investments should help retain agriculturerelated business and environmental assets, while encouraging visitor-, research- and service-related enterprises. 
- Rural Setting: Encourage development patterns that protect and are compatible with agricultural lands. Encourage protection of ecologically valuable, and scenic open lands, and provide for the enjoyment of these features by Watsonville's residents.

- Housing: Encourage a range of housing opportunities with products, sizes, prices, and rents that are consistent with demographic forecasts for Watsonville and the larger region, and the needs of a diverse community.

- Transportation: Increase transportation options and integrate land uses and transportation to improve accessibility and livability goals.

- Human Scale: Encourage pedestrian-friendly neighborhoods, a vibrant downtown, and great streets, parks and plazas, by leveraging public investments and guiding private actions. Safe and comfortable settings should be a goal in both urbanized and new growth areas.

- Downtown: Revitalize Downtown Watsonville by strengthening the array of cultural and retail destinations, broadening available housing options, and making pedestrian-friendly streets and urban environments.

- Infill and Reuse: Encourage redevelopment of underutilized areas, in a manner that supports transit and brings amenities to surrounding neighborhoods and employment centers.

- Diversity: Encourage social and economic diversity within Watsonville, and environments that promote a shared sense of community. 
- Heritage: Protect Watsonville’s agricultural and architectural heritage and, in all improvements, encourage a "sense of place” that is rooted in Watsonville’s unique climate, topography, history, and cultural traditions.

The information within this Local Hazard Mitigation Plan may be used to inform the goals and policies of the General Plan. Goals and policies developed in this plan to mitigate identified hazards will be compatible with the General Plan, and may also provide additional insight to updating General Plan policies and actions regarding public health and safety.

\subsection{Land Use Patterns}

Over the past several years, the City of Watsonville has developed a land use growth strategy to address the conflicting issues of providing affordable housing and conserving the valuable agriculture land that surrounds the city. The population of Watsonville has grown significantly over the past 30 years and it is anticipated to continue to grow. With the pressures of a growing population, the City has identified strategies to balance the housing and infrastructure needs of a larger population with the preservation of agriculture land which is identified as a natural and economic resource for the City.

One such strategy is the approval of the Watsonville Urban Limit Line and Development Timing in 2002. This measure, known as Measure U, established twenty-year, twenty-five-year, and westerly urban limit lines around the City and directs growth into specific unincorporated areas adjacent to the current City boundary. The measure was designed to protect agriculture land and environmentally sensitive areas while still allowing the City to be able to address housing and job creation goals for the next 20 years. 
Implications of risk to the identified adjacent growth areas (Buena Vista, Manabe-Burgstrom and Atkinson Lane) are discussed in each risk profile as appropriate and are shown in Figure 1.0-1.

\subsection{History of Hazardous Events}

The City of Watsonville has experienced several diverse emergency events. Floods are common due to the City’s proximity to various waterways and downstream location of the Pajaro Valley Watershed. The severity of flooding has been a direct result of the extent of development in the area.

Watsonville has also been impacted by seismic events. The greatest amount of damage was due to the 1989 Loma Prieta earthquake which was centered close to the City. In addition to damage caused by ground shaking, liquefaction occurred, and natural gaslines and water mains were severed which caused a greater amount of building collapse and fires throughout the City. Main transportation routes and bridges were damaged and the Watsonville Municipal Airport served as the primary resource for emergency transportation. 


\subsection{Planning Process}

\subsection{The Planning Process}

This section describes the process in which this plan was developed, and includes the federal documentation requirements to be pursuant with the Disaster Mitigation Act of 2000.

A Local Hazard Mitigation Plan had not previously been developed for the City of Watsonville and development of this new Local Hazard Mitigation Plan was the responsibility of the Fire Department and was developed through coordination with the City and Regional Planning Department at California Polytechnic University at San Luis Obispo (Cal Poly) as a graduate professional project. Project direction was given by the Hazard Mitigation Advisory Team. Team members are listed in the acknowledgements section of this document.

This plan was developed between September 2011 and June 2012. Initial stages, (hazard and risk identification and prioritization, and development of mitigation measures and an implementation strategy) were developed with support from Emily Lipoma, a graduate student at Cal Poly San Luis Obispo. Risks were identified and prioritized by the Hazard Mitigation Advisory Team, and the risk and vulnerability assessment was further developed based on topic-focused meetings with resource-specific city employees. Development of the risk and vulnerability assessment was overseen by the project advisory committee at Cal Poly San Luis Obispo (listed in the acknowledgements). The Hazard Mitigation Advisory Team later met to review the risk and vulnerability assessment and provide further guidance regarding hazard risk and prioritization. 
Focused meetings regarding hazard-specific risks and vulnerabilities were then conducted to develop and prioritize mitigation measures. Mitigation and implementation was developed based on designated criteria (specified in Section 5.0).The Hazard Mitigation Advisory Team reviewed the mitigation measures and implementation strategy for broader application to city operation and policy, and consistency with established city policies.

An administrative draft of the risk and vulnerability assessment and mitigation and implementation plan were then reviewed by city departments, officials, and relevant other jurisdictions. Comments were incorporated and the review process of the State was initiated for 'Approval Upon Adoption’.

The following meetings were conducted during development of the risk and vulnerability assessment.

\section{Table 2.1-1 Planning Meetings}

\begin{tabular}{|l|l|l|}
\hline Date & Participants & Meeting Focus \\
\hline October 20, 2011 & Mark Bisbee, Rosa Meyer, Emily Lipoma & Initial project scoping meeting \\
\hline October 2011 & Emily Lipoma, Gary Smith & $\begin{array}{l}\text { Hazardous materials in the city, past } \\
\text { occurrences }\end{array}$ \\
\hline November 2011 & Rex Boyes, Emily Lipoma & City GIS capabilities \\
\hline January 24, 2012 & Hazard Mitigation Advisory Team & $\begin{array}{l}\text { Initial HMAT meeting; hazard } \\
\text { identification and prioritization }\end{array}$ \\
\hline February 6, 2012 & Keith Boyle, Emily Lipoma & General Plan and LHMP consistency \\
\hline February 6, 2012 & SuziAratin, Emily Lipoma & Historic sites \\
\hline February 6, 2012 & Tom Sharp, Valerie Greenway, Emily Lipoma & Flood control and levee protection \\
\hline February 7, 2012 & Paul Horvat, Emily Lipoma & Santa Cruz County LHMP \\
\hline March 28, 2012 & $\begin{array}{l}\text { Rosa Meyer, Mark Bisbee, Keith Boyle, Emily } \\
\text { Lipoma }\end{array}$ & $\begin{array}{l}\text { General Plan Public Hazard Element and } \\
\text { LHMP }\end{array}$ \\
\hline April 26, 2012 & Rex Boyes, Emily Lipoma & GIS data review \\
\hline April 26, 2012 & Hazard Mitigation Advisory Team & Risk and vulnerability review \\
\hline & & \\
\hline & & \\
\hline & & \\
\hline
\end{tabular}

\subsection{Community Participation}




\subsection{Risk and Vulnerability Assessment}

This section identifies the hazards which have the potential to occur in the City of Watsonville.

Descriptions of these risks are based on accurate information regarding the types and scale of damage these hazards present to the City. By using the most accurate and current information, subsequent mitigation and preparedness strategies can be as effective as possible. The hazards identified in this plan are: earthquake, fire, floods, hazardous materials risks and liquefaction, and lesser threats: land subsidence, unreinforced masonry, landslides, airport hazards, natural gas pipeline hazards, civil disturbance/terrorism, drought, expansive soils, tornados and tsunamis. These hazards have been analyzed in regards to the exposure each hazard presents to the City and the vulnerability of the City to each hazard. Hazards which have a very low potential to occur or would have a minimal impact on the City are also discussed. Descriptions and data have been based on historic information of events and input from local and regional organizations. Mapping of these hazards and City facilities and infrastructure has been based on the most current city GIS database.

Hazard identification and prioritization was based on hazards identified by the Public Hazards Element of the General Plan and the Hazard Mitigation Advisory Team. Discussion and analysis of these hazards is based upon input from city authorities in emergency response management, other city officials, and county emergency operations and hazard mitigation documents and personnel. Hazards that are extremely rare or do not have the potential to occur in the City are briefly identified in this plan but are not extensively discussed.

The worst potential disaster that the City of Watsonville might face involves multiple hazards occurring at the same time. A major earthquake could trigger tsunamis, fires and/ or floods. It couldcause damage to dams, stream culverts and storm drains,and inhibit emergency response actions. The City of Watsonville 
plans for and responds to emergency events in accordance with the Santa Cruz County Operation Area Memorandum of Understanding. The City’s Emergency Operations Plan describes the role and operation of the City departments and personnel during a major emergency. In addition to assessing each hazard individually, this Plan explores how the hazards interact, and how mitigation activities for each hazard impact the overall disaster risk in Watsonville (County of Santa Cruz, 2010).

\subsection{Critical Facilities}

The City of Watsonville Hazard Mitigation Advisory Team has identified several critical facilities that are considered instrumental to daily function of the city and to emergency operation.The identified buildings and other infrastructure are used for many purposes, including government administration, emergency services, public works, and recreation. Critical facilities are those facilities whose operation must be maintained in the event of a disaster event to ensure full levels of emergency response, continued government operation to support recovery efforts, or are population centers that have populations that require additional assistance in the event of a disaster. These population centers include senior group residences, schools, and transitional residential facilities. These categories are generally grouped as emergency response, infrastructure, and population centers, although this does not reflect the priority of individual facilities for mitigation.All critical facilities support resiliency of the City's population and operation and are thus identified for mitigation in the event they are at risk.

City operation facilities are facilities identified by the Hazard Mitigation Advisory Team as crucial to both city operation and emergency services. Two of these facilities, the police headquarters and fire station \#2 are also communication centers. These facilities provide critical emergency communication throughout the City, to areas outside the City, and to NetComm facilities in Santa Cruz, which is the City’s emergency response dispatch center. 
Although most of the critical facilities are within city limits, many are not. The City of Watsonville provides fire and water service to some county residents which requires facilities outside of the city limit. Several other city facilities, such as the Buena Vista Landfill, the Wastewater Treatment Plant, and the Corralitos Water Treatment Facility are located outside of the City, on city-owned land but are connected to the City by roads and pipelines outside of the City's jurisdiction. Several water pumping stations are outside of the city at the mouth of the Pajaro River. Additionally, the levees in and around Watsonville are owned by the City, but are managed and controlled by Santa Cruz County and a joint managing agency. For the purpose of the risk and vulnerability assessment, critical facilities have been identified regardless of location and are shown in Tables 3.1-1, 3.1-2, 3.1-3, 3.1-4, 3.1-5, 3.1-6. Relationship to the City’s jurisdiction is discussed within Section 5.0 Mitigation Strategy.

Daycare facilities were identified by the Hazard Mitigation Advisory Team as critical population facilities because particular attention in emergency response or evacuation may be required. There are many daycare facilities within the city and they will be discussed in regards to high risk hazards because of their number and potential to change location. A complete list of daycare facilities included in this analysis is in Appendix B.

Table 3.1-1 City Operation Facilities

\begin{tabular}{|l|l|l|}
\hline \multicolumn{1}{|c|}{ Description/ Name of Facility } & \multicolumn{1}{c|}{ Address } & \multicolumn{1}{c|}{ Owned by City? } \\
\hline Civic Center (Includes EOP Center) & 275 Main St & Yes \\
\hline Airport & 100 Aviation Way & Yes \\
\hline Police Headquarters (Communication Center) & 215 Union St & Yes \\
\hline Fire Station 1 & 115 Second St & Yes \\
\hline Fire Station 2 (Communication Center) & 370 Airport Blvd & Yes \\
\hline City Hall & 250 Main St & Yes \\
\hline Watsonville Community Hospital & 75 Nielson St & No \\
\hline
\end{tabular}


Table 3.1-2 PrimaryRed Cross Shelters

\begin{tabular}{|l|l|}
\hline Description/Name of Facility & Address \\
\hline Watsonville High School & 250 East Beach St \\
\hline Cesar Chavez Middle School & 440 Arthur Rd \\
\hline Rolling Hills Middle School & 130 Herman Rd \\
\hline Bradley Elementary School & 321 Corralitos Rd \\
\hline Lakeview Middle School & 2350 East Lake Ave \\
\hline Ohlone School & 21 Bay Farms Rd \\
\hline Pajaro Middle School & 250 Salinas Rd \\
\hline Santa Cruz County Fairgrounds & 2601 East Lake Ave \\
\hline Corralitos Community Free Church & 26 Browns Valley Rd \\
\hline Corralitos Grange & 165 Little Corral Way \\
\hline Holy Eucharist Catholic Church & 527 Corralitos Rd \\
\hline Watsonville/Aptos Adult Education & 280 Main St \\
\hline Pajaro Valley High School & 500 Harkins Slough Rd \\
\hline Salesian Sister School & 605 Enos Ln \\
\hline Our Lady Help of Christians & 2401 East Lake Ave \\
\hline Source: City GIS Data & \\
\hline
\end{tabular}

Table 3.1-3Critical City Infrastructure

\begin{tabular}{|l|l|}
\hline Infrastructure & Location \\
\hline Pajaro River Levees & Pajaro River \\
\hline Salsipuedes Creek Levees & Salsipudes Creek \\
\hline City of Watsonville Wells & Undisclosed \\
\hline Wastewater Treatment Plant & 401 Panabaker Ln \\
\hline AT\&T Hub & $\begin{array}{l}\text { 340 Rodriguez St (Location } \\
\text { Unconfirmed and not mapped) }\end{array}$ \\
\hline PG\&E Substation & $\begin{array}{l}\text { Walter St (Location Unconfirmed } \\
\text { and not mapped) }\end{array}$ \\
\hline PG\&E Substation & $\begin{array}{l}\text { Minto(Location Unconfirmed and } \\
\text { not mapped) }\end{array}$ \\
\hline PG\&E Substation & $\begin{array}{l}\text { Atkinson Lane (Location } \\
\text { Unconfirmed and not mapped) }\end{array}$ \\
\hline PG\&E Substation & $\begin{array}{l}\text { East Lake (Location Unconfirmed } \\
\text { and not mapped) }\end{array}$ \\
\hline Corralitos Filtration Plant & 6 Eureka Canyon Rd \\
\hline $\begin{array}{l}\text { Harkins Slough Bridge at } \\
\text { Watsonville Slough }\end{array}$ & \\
\hline $\begin{array}{l}\text { Harkins Slough Bridge at Struve } \\
\text { Slough }\end{array}$ & \\
\hline Main Street Bridge at Pajaro River & \\
\hline $\begin{array}{l}\text { Riverside Bridge at Salsipuedes } \\
\text { Creek }\end{array}$ & \\
\hline East Lake Bridge at Corralitos Creek & \\
\hline $\begin{array}{l}\text { Green Valley Bridge at Corralitos } \\
\text { Creek }\end{array}$ & \\
\hline Holohan Bridge at Corralitos Creek & \\
\hline $\begin{array}{l}\text { Harkins Slough Bridge at West } \\
\text { Branch Struve Slough }\end{array}$ & \\
\hline Highway 1 Bridge at Struve Slough & \\
\hline Riverside Bridge at Pajaro River \\
Source: City GIS Data & \\
\hline
\end{tabular}


Table 3.1-4 Special Population Centers

\begin{tabular}{|l|l|}
\hline Center & Location \\
\hline Restar Residential Hotel & 15 West Lake Ave \\
\hline Wall Street Inn & 30 West Beach St \\
\hline Plaza Hotel & 825 Walker St \\
\hline Stag Hotel & 117 West Beach St \\
\hline Women's Shelter & 115 Brennon \\
\hline Salvation Army & 112 Grant Ave \\
\hline Valley Convalescent Hospital & 919 Freedom Blvd \\
\hline $\begin{array}{l}\text { Watsonville Nursing and } \\
\text { Rehabilitation Center }\end{array}$ & 525 Auto Center Dr \\
\hline Sunbridge Care Center & 535 Auto Center Dr \\
\hline Paloma House & 321 Beach St \\
\hline Rillera's Guest Home & 40 Fletcher Ct \\
\hline Valley Haven Care Home & 157 Herman Ave \\
\hline Valley Haven Care Home II & 99 Airport Blvd \\
\hline Watsonville Manor & 311 Montecito \\
\hline Independence Square Apartments & 1355 Madison \\
\hline Pajaro Vista & 1955 Pajaro \\
\hline Paloma Del Mar & 2030 Pajaro \\
\hline Daycare Facilities & $\begin{array}{l}\text { There are 251 daycare facilities in } \\
\text { the City as of 2010 }\end{array}$ \\
\hline
\end{tabular}

Source: City GIS Data, Pajaro Unified School District as of 2010 
Table 3.1-5SchoolsWithin City Limits

\begin{tabular}{|c|c|c|}
\hline Name & Type & Address \\
\hline E. A. Hall Middle School & Middle & 201 Brewington Road \\
\hline Watsonville High School & High & 250 East Beach St \\
\hline Hyde Elementary School & Elementary & 125 Alta Vista Ave \\
\hline Starlight Elementary School & Elementary & 225 Hammer Dr \\
\hline Cesar Chavez Middle School & Middle & 440 Arthur Dr \\
\hline Rolling Hills Middle School & Middle & 130 Herman Rd \\
\hline Freedom Elementary School & Elementary & 25 Holly Dr \\
\hline Mintie White School & Elementary & 515 Palm Ave \\
\hline MacQuidy School & Elementary & 330 Martinelli St \\
\hline Ann Soldo School & Elementary & 1140 MenascoDr \\
\hline Green Valley Christian School & Private & 376 South Green Valley Rd \\
\hline Notre Dame Private School & Private & 656 Main St \\
\hline Calabasas Elementary School * & Elementary & 202 Calabasas Rd \\
\hline Amesti Elementary School * & Elementary & 25 Amesti Rd \\
\hline Linscott Charter School & Elementary & 220 Elm St \\
\hline Pajaro Valley High School & High & 500 Harkins Slough Rd \\
\hline Landmark Elementary School & Elementary & 235 Ohlone Parkway \\
\hline Radcliff Elementary School & Elementary & 550 Rodriguez St \\
\hline Watsonville High School & High & 250 East Beach St \\
\hline Pacific Coast Charter & $\mathrm{K}-12$ & 294 Green Valley Rd \\
\hline AVCI & & 112 Diamond $\mathrm{Dr}$ \\
\hline Cabrillo College & $\begin{array}{l}\text { Junior } \\
\text { College }\end{array}$ & 310 Union St \\
\hline Pajaro Valley Community Day School & & 165 Harkins Slough Rd \\
\hline Duncan Holbert School & & 140 Herman Ave \\
\hline CEIBA College Preparatory Academy & Charter & 280 Main St \\
\hline
\end{tabular}

Source: City GIS Data, Pajaro Valley Unified School District 2010

*These school sites are not within the city limits, but they are within the Pajaro Valley Fire Contract Area.

Historic sites are listed Table 3.1-6 (historic sites of interest are listed in appendix A) due to their importance in preserving the cultural heritage of Watsonville. These sites are identified for potential mitigation from hazards, although the priority of this mitigation is low. Historic sites and historic sites of interest will only be discussed in relation to high risk hazards. 


\section{Table 3.1-6 Historic Sites}

\begin{tabular}{|l|l|}
\hline Address & Name \\
\hline 332 E Beach Street & Bockius-Orr House \\
\hline 128 E Beach Street & Judge Lee House \\
\hline 261 E Beach Street & Richard Pearson Home \\
\hline 30 West Beach Street & Wall Street Inn \\
\hline 12 Brennan Street & Watsonville Woman's Club \\
\hline 225 E Lake Ave & \\
\hline 305 E Lake Ave & Mitchell Resetar House \\
\hline 335 E Lake & \\
\hline 280 Main Street & Porter Building \\
\hline 406 Main Street & Lettunich Building \\
\hline 418 Main Street & Mansion House \\
\hline 350 Main Street & Watsonville Plaza \\
\hline 426 Main Street & Kalich Building \\
\hline 139 Maple Street & Horgan House \\
\hline 37 Sudden Street & Pajaro Valley Arts Council \\
\hline
\end{tabular}

Source: City of Watsonville GIS

\subsection{Hazard Assessment and Prioritization}

A community’s risk assessment, mitigation strategies, and preparedness efforts must be founded on accurate and recent information in order to accurately determine the types and scale of damage hazards pose to the community. This section of the LHMP contains a discussion of those hazards identified as potential threats to the city and the exposure and vulnerability of the City to these hazards. These risks have been identified based on historical information of events as well as input from geologic, climatic, and fire specialty sources. Probable damage and consequences to the City's quality of life are discussed in the vulnerability assessment.

The City of Watsonville is exposed to many natural and human-caused hazards which vary in their potential intensity and impact. This plan addresses the natural and human-caused hazards that present a risk to the City. Risk was determined by the Hazard Mitigation Advisory Team through discussion of past events, the extent to which a hazard could impact City operations and populations, and how likely 
events could occur within the city. These factors determined the overall risk to the city. Additional information of specific risk determination is discussed for each identified hazard.

Some hazard events might exacerbate the potential for additional hazards to occur. In addition to discussing the individual potential and effects of each hazard, this plan explores how the hazards are interrelated and how mitigation actions can reduce the overall disaster risk to the City.

Table 3.2-1 describes the risk for each identified hazard. Hazards with a Major or Moderate risk were discussed in depth in the hazard risk assessment while hazards with a Low risk are briefly described.

Hazards that the City is not at risk of are described in minor detail at the end of this section.

\section{Table 3.2-1 Hazard and Risk Associated for the City of Watsonville}

\begin{tabular}{|l|l|l|}
\hline Hazard & Risk & Hazard Profile Included in Plan \\
\hline Airport Hazard & Low & Yes \\
\hline Avalanche & No & Minor Discussion of Risk \\
\hline Civil Disturbance/Terrorism & Low & Yes \\
\hline Coastal Erosion & No & Minor Discussion of Risk \\
\hline Coastal Storm & No & Minor Discussion of Risk \\
\hline Dam Failure & No & Minor Discussion of Risk \\
\hline Drought & Low & Yes \\
\hline Earthquake & Major & Yes \\
\hline Expansive Soils & Low & Yes \\
\hline Extreme Heat & No & Minor Discussion of Risk \\
\hline Fire (Urban, Industrial and Wildfire) & Major & Yes \\
\hline Flood & Major & Yes \\
\hline Natural Gas Pipeline Hazard & Moderate to Low & Yes \\
\hline Hailstorm & No & Minor Discussion of Risk \\
\hline Hazardous Materials & Moderate & Yes \\
\hline Hurricane & No & Minor Discussion of Risk \\
\hline Land Subsidence & Moderate to Low & Yes \\
\hline Landslide & Moderate to Low & Yes \\
\hline Liquefaction & Moderate & Yes \\
\hline Seiche & No & Minor Discussion of Risk \\
\hline Tornado & Low to No & Yes \\
\hline Tsunami & Low to No & Yes \\
\hline Unreinforced Masonry & Moderate to Low & Yes \\
\hline Vehicle Accident (Train, Truck, \\
Car) & Low & Yes \\
\hline Volcano & & \\
\hline Winter Snow Storm & No & Minor Discussion of Risk \\
\hline Now & No & Minor Discussion of Risk \\
\hline & Por & \\
\hline
\end{tabular}

Source: Hazard Mitigation Advisory Team, General Plan Public Hazards Element 


\subsection{Earthquake Hazard Profile (Major Risk)}

An earthquake is caused by a release of strain within or along the edge of the Earth's tectonic plates which produces ground motion and shaking, surface fault ruptures and ground failure. The severity of the motion increases with the amount of energy released, decreases with distance from the causative fault or epicenter, and is amplified by soft soils. Although earthquakes can last for only a few seconds, massive damage and extensive casualties can result (County of Santa Barbara, 2004). The extent of a seismic risk is based upon the relation of an area to fault lines, the potential for activity that these fault lines exhibit, and the geologic conditions of the area, such as the types of soils or slopes.

Several zones are located within Santa Cruz County and another fault line is located west of the City offshore. Movement along these faults can cause fault-related surface deformation and movement along these faults is likely to damage structures, roads, utilities, and other facilities.

There are several methods of measurement for earthquakes. The Richter magnitude scale determines the amount of ground displacement or shaking that occurs near the epicenter. The Richter scale is logarithmic and each one-point increase on the scale corresponds to a 10-fold increase in the amplitude of the seismic shock waves and a 32-fold increase in released energy. This scale has now been replaced by the Moment Magnitude scale which characterizes the amount of energy released by an earthquake. The Modified Mercalli Intensity Scale measures ground shaking intensity in terms of perception and damage and takes into account localized earthquake effects (County of Santa Cruz 2010, County of Santa Barbara 2004). Peak ground acceleration is a measure of the strength of ground movement. PGA is used to anticipate the risk of damage by showing earthquake ground motions that have a specified probability of being exceeded within a 50 year period. (County of Santa Cruz 2010, County of Santa Barbara 2004). 
Earthquake damage is dependent upon geologic conditions, the quality of construction, the magnitude of the earthquake, the distance from the epicenter, and type of faulting that generates the earthquake. Ground motion is the primary cause of damage and injury during an earthquake and it can result in surface rupture, liquefaction, landslides, lateral spreading, differential settlement, tsunamis, building failure, and broken utility infrastructure (County of Santa Cruz 2010).

Structural failure and fires are typically the most hazardous results of earthquakes. Many earthquakeinduced fires are due to ruptured electric or gas lines and can be exacerbated by damaged water mains. The potential for structural failure is generally the result of the age and type of building construction.

Earthquakes are the primary seismic risk, but a number of hazards can occur in conjunction with earthquakes, which together constitute a seismic risk. Landslides and liquefaction have the potential to occur in relation to seismic risk. Both of these hazards are further discussed later in this document (County of Santa Cruz 2010). 
Figure 3.3-1 Earthquake Fault Lines

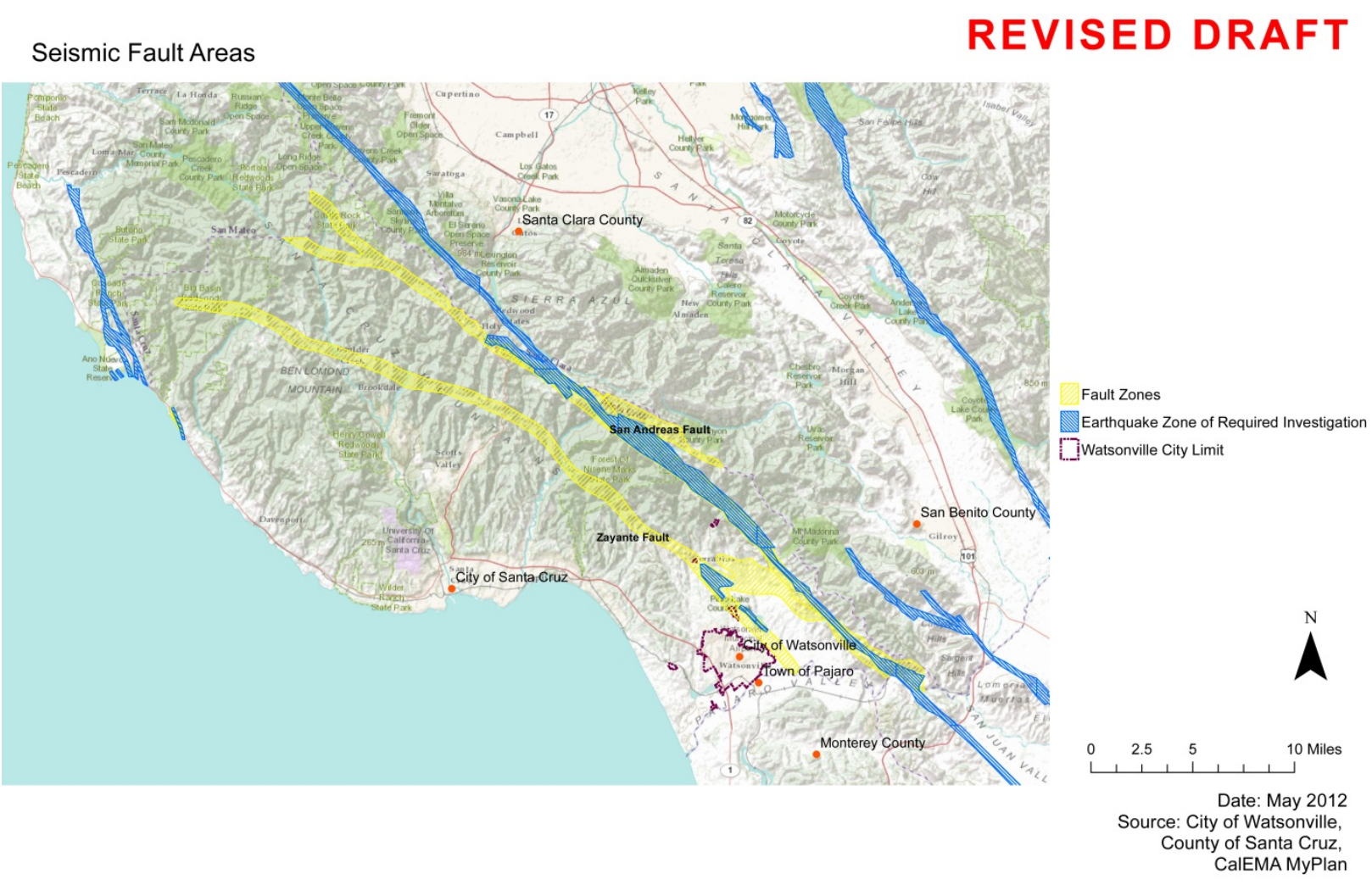

\section{A Location}

The Zayante Fault runs through Pinto Lake and although this fault has not been active in the past 10,000 years, it is considered potentially active and an Earthquake Zone of Required Investigation is identified for areas in the immediate proximity to Pinto Lake. Areas of this zone are within the city limits and could experience surface rupture which could severely impact structures and infrastructure. The San Andreas Fault has been active in the historic period, most notably during the 1989 Loma Prieta earthquake. This fault line is only a few miles outside of the city limits and runs across highway 152 which is an evacuation route outside of the city. This roadway was disrupted during the 1989 earthquake and there is a potential for another seismic event from the San Andreas fault to impact this roadway and the city once again. 
Past earthquake occurrences and the City's close proximity to active fault lines have demonstrated that the City is vulnerable to earthquakes. In the event of an earthquake, risk would not be limited to a particular location within the City. Rather, the entire city would be affected and damage would be dependent upon structural stability and the potential for seismically-associated risks to occur.

\section{B Extent: Magnitude or Severity}

Several of the faults near the City are considered active (showing signs of recent geologic movement, within the past 10,000 years), or potentially active (showing evidence of movement from the Pleistocene era or younger).

The risk of seismic activity in the City of Watsonville is affected by the distance between the City and active fault lines and the potential for these fault lines to experience high-magnitude earthquakes. If a fault line further away from the City were to cause an earthquake, the effect on the City would be greater if it was a higher magnitude earthquake rather than a smaller magnitude. As discussed in the probability of future events section, there is a 21\% probability of a M 6.7 or higher earthquake occurring within the next several years. The severity of potential earthquakes is dependent upon how close the epicenter is to the City, structural stability and the occurrence of additional hazard events triggered by the earthquake (such as liquefaction, landsliding, or fires).

\section{Previous Occurrences}

The Santa Cruz region is seismically active and the City has experienced many large and small earthquakes over the past 150 years. The northern and central California region is seismically active and 
many of the earthquakes centered outside of the City can be felt within Watsonville and impact the city. Earthquakes that are centered closest to the City will have the greatest impact on and disruption of City facilities. The following section lists the previous high magnitude earthquakes which occurred in close proximity to the City or earthquakes centered further way but of a sufficient magnitude to impact the City of Watsonville. While the area has experienced a number of earthquakes, the most destructive events were the 1906 San Francisco earthquake and the 1989 Loma Prieta earthquake, discussed below.

Table 3.3-1 shows moderate to large earthquakes that were recorded in Santa Cruz. Cited magnitudes for earthquakes before 1906 are estimates based on descriptions of occurred damage.

\section{Table 3.3-1 Previous Large Earthquakes in the Santa Cruz County Area}

\begin{tabular}{|l|l|l|}
\hline Data & Magnitude(Richter) & Description \\
\hline February 26, 1864 & Magnitude 6 & Centered in the Southern Santa Cruz Mountains \\
\hline October 8, 1865 & Magnitude 6.5 & Centered in the Santa Cruz Mountains \\
\hline March 26, 1884 & Magnitude 6 & Centered in the Santa Cruz Mountains \\
\hline April 24, 1890 & Magnitude 6.25 & Centered in the Pajaro Gap \\
\hline April 18, 1906 & Magnitude 8.3 & Centered off the Western Coast of San Francisco \\
\hline October 1926 & Magnitude 6.1 & $\begin{array}{l}\text { Two large earthquakes and several aftershocks caused } \\
\text { damage in the Monterey Bay area. The epicenter was } \\
\text { believed to be north of Monterey Bay. }\end{array}$ \\
\hline October 17, 1989 & Magnitude 7.1 & $\begin{array}{l}\text { Centered in the Santa Cruz Mountains. The initial quake } \\
\text { and many after shocks damaged infrastructure throughout } \\
\text { the region. Estimates approximate that \$60 million in } \\
\text { damages, and that approximately 1,900 structures were } \\
\text { damaged during the earthquake. Included in that estimate } \\
\text { was approximately \$5 million in damage to public } \\
\text { facilities, including the water system, sewage treatment } \\
\text { plant, the Pajaro Bridge, Main St, Union St, Green Valley } \\
\text { Road, and the recreation center. }\end{array}$ \\
\hline
\end{tabular}

Source: County of Santa Cruz 2010

The 1989 Loma Prieta earthquake was likely the foremost transitive event to the City of Watsonville in its recent history if not in the history of the city. The initial earthquake coupled with thousands of aftershocks instantly disrupted life for all city residents, particularly the 1,500 people who were instantly homeless as 550 residences were determined to be unsafe. There were also permanent impacts on the 
economic stability of the City. As discussed in Table 3.3-1, the magnitude 7.1 earthquake caused approximately $\$ 60$ million dollars in damage. The city received a fraction of this amount, \$10.5 million dollars, from FEMA for rebuilding the city. Although the city has come far in the rebuilding and redevelopment process, recovery is still ongoing and it should not be forgotten that a similar event could occur at any point (Schwab et al., 1998).

\section{Probability of Future Events}

There are at least six major faults and fault systems within or near the City of Watsonville, placing it in an area of high seismic risk. Because earthquakes can cause severe damage over a long distance, the Santa Cruz area remains at risk from continued seismic activity along the many faults in the greater San Francisco Bay region. The reduction of seismic stresses that occurred in the Loma Prieta earthquake did nothing to relieve, and possibly increased, stresses within other faults, including other sections of the San Andreas Fault. To clarify the extent of future earthquake risk, a partnership of the United States Geologic Service, The California Geologic Survey, and the Southern California Earthquake Center was formed in September 2004 to provide a uniform forecast. Known as the Working Group on California Earthquake Probabilities, this group evaluated and systemized currently available historic and paleoseismic information to produce a probabilistic seismic hazards analysis to indicate the type of future earthquakes. One product of this analysis is a method of estimating the probability of ground shaking. The 30-year probability of an $M \geq 6.7$ earthquake on the northern segment of the San Andreas Fault is $21 \%$ and on the San Gregorio Fault is 6\%. Other faults within the region can also cause damage in the county, including the Hayward-Rogers Creek Fault that has a 31\% probability of having an $M \geq 6.7$ earthquake in the next thirty years (County of Santa Cruz 2010). 
Table 3.3-2 Ten Most Likely Damaging Earthquake Scenarios in California

\begin{tabular}{|l|l|l|}
\hline $\begin{array}{l}\text { Ten Most Likely Damaging } \\
\text { Earthquake Scenarios }\end{array}$ & $\mathbf{3 0 - Y e a r ~ P r o b a b i l i t y ~}$ & Magnitude \\
\hline Rodgers Creek & $15.2 \%$ & 7.0 \\
\hline Northern Calaveras & $12.4 \%$ & 6.8 \\
\hline Southern Hayward & $11.3 \%$ & 6.7 \\
\hline Northern + Southern Hayward & $8.5 \%$ & 6.9 \\
\hline Mt. Diablo & $7.5 \%$ & 6.7 \\
\hline Green Valley-Concord & $6.0 \%$ & 6.7 \\
\hline San Andreas: Entire N. CA segment & $4.7 \%$ & 7.9 \\
\hline San Andreas: Peninsula segment & $4.4 \%$ & 7.2 \\
\hline Northern San Gregorio segment & $3.9 \%$ & 7.2 \\
\hline $\begin{array}{l}\text { San Andreas: Peninsula + Santa } \\
\text { Cruz segment }\end{array}$ & $3.5 \%$ & 7.4 \\
\hline
\end{tabular}

Source: Santa Cruz County LHMP

Because the ten most likely future earthquakes in the Bay area occur on faults throughout theregion, the impact and potential losses reported here reveal significant risk for the entire Bayarea region including the City of Watsonville (County of Santa Cruz 2010).

\section{E Climate Change Considerations}

Earthquakes are not influenced by the climate, and thus seismic activity is not anticipated to be influenced by climate change. However, climate change could impact hazards such as tsunamis, fires, and floods which can be triggered by an earthquake. In the event that climate change increases the risk of these associated hazards, there may be a greater potential for an earthquake to trigger a tsunami, fire, or flood and for the triggered event to have a greater severity. 


\section{F Vulnerability Assessment}

The vulnerability of a community to earthquake hazard is based on a variety of factors including proximity to active and inactive faults, the age of structures, the density of the population and development, the value of property and infrastructure, the construction materials used in residential and non-residential buildings, and the location of critical facilities in a community. Recent history indicates that Watsonville has a very high vulnerability to earthquakes due to proximity to faults, density of population and development within the floodplains of the many creeks and rivers, which are subject to liquefaction.

One or more moderate to large sized earthquake will likely shake the City of Watsonville during the life span of most residents. Older homes will be most affected by their age, structural design, and materials. Modern homes will normally fare better in earthquakes but the 1989 earthquake showed that this isn't necessarily the case. Some older homes fared better than newer ones due to location and design.

A large earthquake on the San Andreas Fault will:

- Damage roads, bridges, and critical structures, and could severely damage many homes in the City.

- Liquefaction will occur along alluvial areas throughout the Pajaro Valley, and along streams such as Corralitos Creek, Salsipuedes Creek, and the Pajaro River.

- Fault rupture will occur near the major faults, and ground cracking will occur through the hillslopes and near the Fault Zones. This may affect the Pinto Lake area and Corralitos filtration plant. 
- As indicated in the section on landsliding, earthquakes can reactivate landslides, and contribute to the initiation of other landslides.

\section{G Types and Numbers of Existing Buildings, Facilities, and Infrastructure}

Past experience has shown that the entire city is vulnerable to earthquakes. Vulnerability of individual structures, facilities, and infrastructure will be dependent upon building and material type. Additional hazardous events such as liquefaction, landsliding, or fires may occur in connection with seismic activity which increases the vulnerability of buildings, facilities and infrastructure. The entire downtown commercial area in the city has a low to moderate liquefaction potential and the rest of the city is in a high liquefaction potential area. The remainder of the town is at risk for severe ground shaking.

Historic structures may be more vulnerable to seismic activity due to out dated building practices and weakened materials. However without site comparison or specific site evaluation of each structure, no one site is determined to be at a greater risk than any other.

Due to the uniform level of risk throughout the city, vulnerability of critical facilities to seismic activity is neither higher nor lower for any particular facility based on location.

\section{H Description of Land-Uses and Development Trends}

As with most communities, increased housing costs have resulted in the need to provide higher density housing and affordable housing. Anticipated growth will occur in areas where urban services are available and additional development will be infill, reuse, and development of existing residential properties. 
Areas that are identified for future growth share the same level of risk to seismic activity as the rest of the city. Future development outside of the city limits will not be at a higher or lower risk to seismic activity than development within the city. Seismic safety standards are a requirement for all building permits. As infrastructure is repaired or replaced updated seismic safety standards are incorporated.

\subsection{Fire Profile (Major Risk)}

The City of Watsonville is prone to several fire hazards: urban fire, industrial fire, and to a lesser extent, wildland fire. Each of these fire types carries particular risks to the population based on location, potential for risk, and materials involved. Urban fires may involve structures or vehicles and the potential for urban fires is particularly high in the city due to older buildings and overcrowding. Industrial fires are a risk due to the concentration of cold storage plants, canneries and packing plants in the city. These large buildings and chemical and equipment use pose a particular fire risk.

Wildfires may be defined as any unwanted fire involving outdoor vegetation and are influenced by fuel, weather and topography. In the case of Watsonville, wildfires may occur in vacant lots, highway medians, parks, and rural residential areas. 
Figure 3.4-1 Fire Hazard Severity Zones

Fire Hazard Severity Zones and Critical Facilities

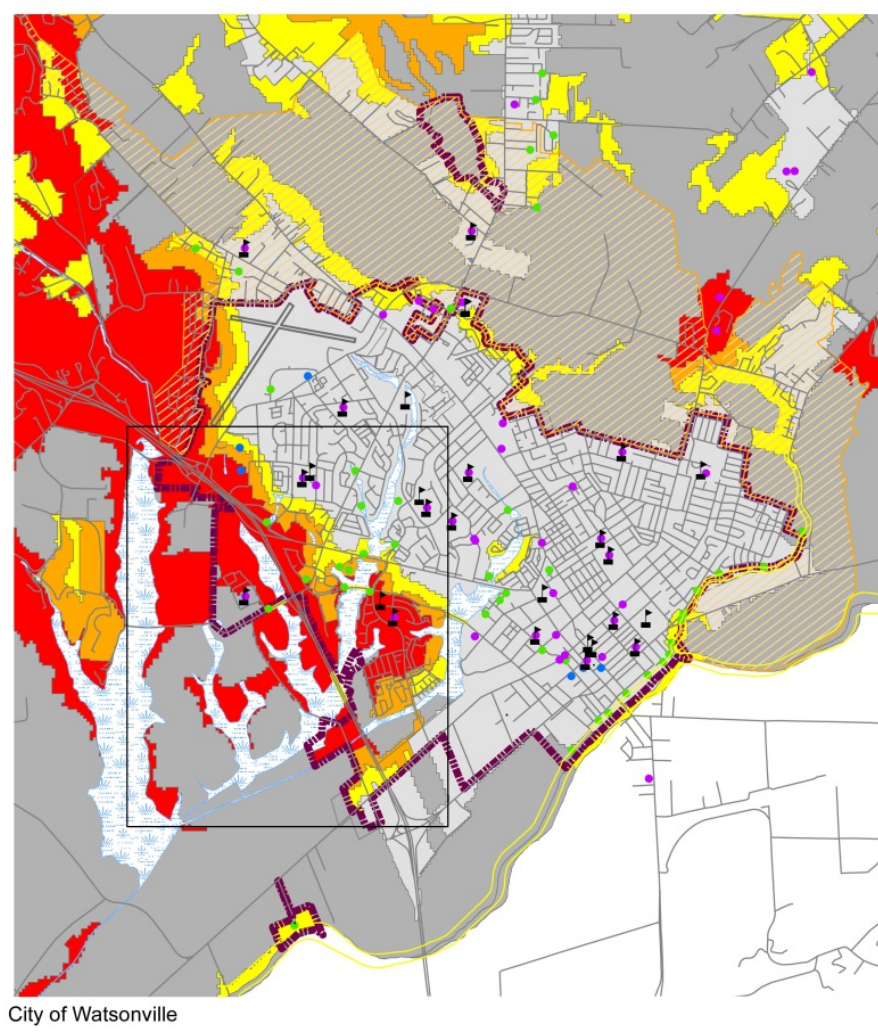

\section{DRAFT}

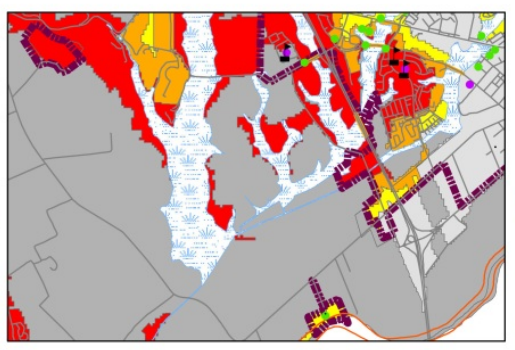

Buena Vista Landfill and Wastewater Treatment Plant
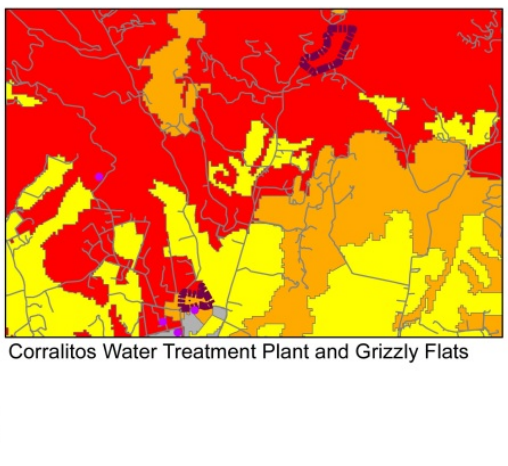

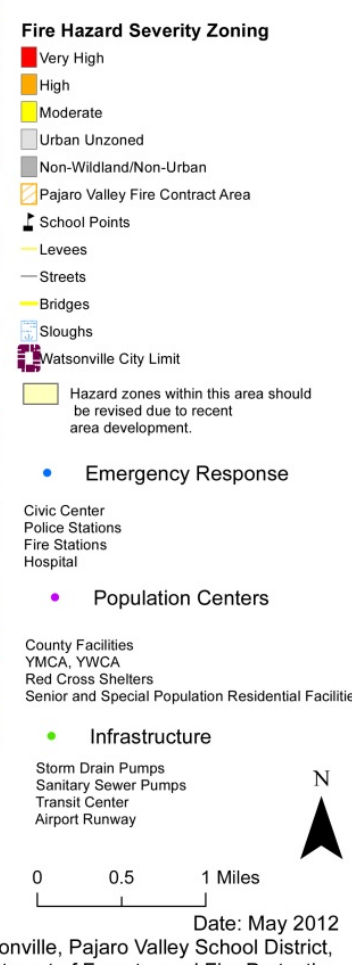

Source: City of Watsonville, Pajaro Valley School District, California Department of Forestry and Fire Protection

\section{A Location}

Due to the density of Watsonville, and the type and age of structure commonly found within the city, urban fires are common. Additionally there is a substantial amount of industrial operations within the city. There is a potential for urban fire throughout the city, and a potential for industrial fire in the western area of the city where industrial activity is prevalent.

Although wildland is prevalent around the city, there is little wildland area within the City. Existing wildland hazard is mostly located along the western and southern boarders of the city. Existing mapped 
data of wildfire hazard severity zones does not accurately portray recent development. It is likely that actual risk to the city is much lower due to the reduction in wildland area within the city.

\section{B Extent: Magnitude or Severity}

Wildifire risk ranges from moderate to very high, and most of the City is urban unzoned area and does not have a wildfire risk.

\section{Previous Occurrences}

The City of Watsonville has had many fire events due to the buildings and economic activities within the City. There have been very few wildfires within the City due to the minimal amount of wildland within the City limits, although the dense building conditions and age of the City's buildings create a risk for urban fires. The industrial buildings within the city create an additional risk of industrial fires.

\section{Probability of Future Events}

Although there is very little wildland within the City, the area that is present, particularly the Grizzly Flats in the hills to the north of the city, has a very high potential for a wildfire.However, existing mapped data of wildfire hazard severity zones does not accurately portray recent development. It is likely that actual risk to the city is much lower due to the reduction in wildland area within the city.

The probability of urban or industrial fires is based on the type of structure, the age of the structure and the density of buildings. Probability of industrial fire is also influenced by the activity within the 
structure. [Precise information regarding structure type and age is unknown, and thus more specific probabilities for urban and industrial fire cannot be determined.]

\section{E Climate Change Considerations}

Climate change has the potential to create dryer conditions that would influence the frequency of wildfires. However, due to the small amount of area in the City classified as wildland, the influence of climate change on wildfires in Watsonville will most likely be minor.

Dryer climate conditions potentially caused by climate change may influence the frequency of urban or industrial fires by creating conditions that favor fires. However significant influences of climate change on urban or industrial fires will most likely only occur under very extreme climate change instances.

\section{F Vulnerability Assessment}

Analysis of fire potential indicates different potentials for wildfire, urban fire and industrial fire. There is very little land in the City that is subject to the threat of wildfire due to the built-out nature of the City. However land on the western border of the City, and all of the Buena Vista Landfill and the Grizzly Flats area has a moderate to very high risk of wildfire due to the presence of wildland vegetation. The Corralitos Filtration Plan has a high threat of wildfire, and Ramsey Park has a moderate threat of wildfire because of the vegetation present.

A greater risk of urban and industrial fire is present due to the density and age of the buildings within the City. There is also a risk of industrial fire due to the many industrial operations in the City. 


\section{G Types and Numbers of Existing Buildings, Facilities, and Infrastructure}

With the information available, risk to critical facilities cannot be specifically determined and vulnerability can only be assessed generally. Specific locations at risk to urban and industrial fire is unknown.

\section{H Description of Land-Uses and Development Trends}

As demand for housing increases, residential construction will spread into existing open space and varying vegetation types. This construction will increase the area of the wildland urban interface and increase the wildland urban interface threat. The amount of wildland area may be reduced, although additional development could increase the fuel potential of the area.

Infill development may increase the threat of urban fire by exacerbating existing building stock

overcrowding. However this threat is likely to be reduced by superior building standards and practices and best planning practices.

The compact nature of the City creates an area that is easierprotect from all types of fire. The city is relatively accessible and does not suffer from the poor access and remoteness found in the County. 


\subsection{Flood Profile (Major Risk)}

A flood occurs when a waterway receives a discharge greater than its conveyance capacity. Floods may result from intense rainfall, localized drainage problems, or failure of water control or supply structures such as levees, dams, or reservoirs. Floodplains are low laying lands adjacent to rivers, lakes, and oceans that are subject to recurring floods.

Flood severity is determined by the quantity and rate at which water enters the waterway, increasing volume and velocity of water flow. Several factors determine the severity of floods, including rainfall intensity and duration, the rate of surface runoff, creek and storm drain capacity, surface permeability, and geographic characteristics of the watershed such as shape and slope. It should be noted that a stream or river can crest long after precipitation has ceased. A particularly large amount of rainfall in a short period of time can result in flash flood conditions, which is when the travel of the peak flow from one end of the watershed to the other is less than six hours.

Periods of very heavy rainfall are common throughout fall and winter months and the Pajaro River can rise to flood stage in a short period of time. Floodwaters can carry large objects downstream with a strong force strong and in other areas most injuries or deaths occur when people are swept away by flood currents. However the floods which effect Watsonville are described as slow moving and standing water type floods. Property damage generally occurs as a result of inundation by sediment-saturated water. Floodwaters also saturate materials and earth resulting in the instability, collapse, and destruction of structures. 
The U.S. Army Corps of Engineers (USACE) has identified three principle flood issues for the City of Watsonville. There is inadequate interior drainage which causes shallow flooding from accumulated surface runoff. Overtopping of the Salsipuedes Creek or Pajaro River is possible and the USACE has indicated that it is reasonable to assume the Pajaro River levees could fail in a major event. The Salsipuedes Creek levees may remain intact during a 100-year event because of limited overflow volume and potential duration of such a flooding event. Overflow of the Corralitos Creek upstream of levees is also a potential, which would, and has, flooded the eastern area of the City, particularly because flood waters are unable to reenter waterways downstream because of levees (FEMA 2006).

\section{Levee Failure}

The levee system of the Pajaro Valley watershed began in 1949 when the an initial 11.5 mile stretch of levees was constructed along the Pajaro River and 3 miles was built on the Salsipuedes Creek. Several sections have experienced breeches due to earthquake damage or high water levels.

There are currently 11.5 miles of levees along the Pajaro River and 3 miles of levees along the Salsipuedes Creek protecting the City from flooding. The existing channel capacity in the lower reaches of the Pajaro River is approximately 22,000 cubic feet per second (cfs) which is well below the expected 100-year flood event of 44,400 cfs. The levee system has been breached in the past resulting in extensive flooding in the city.

Levee breaches or overtopping may cause flooding in the City of Watsonville, Santa Cruz County, the Town of Pajaro or all three. Structural failure of the levees may be induced by subsidence, seismic activity, or water levels higher than levee capacity. Structural failure could lead to levees being breached or overtopping in the event of a flood event. 
In 1963 the USACE recommended that the levees at the Pajaro River, and Salsipuedes and Corralitos Creeks be modified for additional protection. After advanced design stages had progressed, local support was withdrawn and the project was not completed. More recent plans have advanced to fortify the existing levee system, although they remain in the planning stages (FEMA 2006). The USACE project proposal would construct a ring levee to provide protection to the City of Watsonville and the Pajaro Community for the $1 \%$ (or 100-year) recurring flood event. The project is scheduled to release an EIS in February of 2013.

\section{Figure 3.5-1 Areas of Flood Hazard}

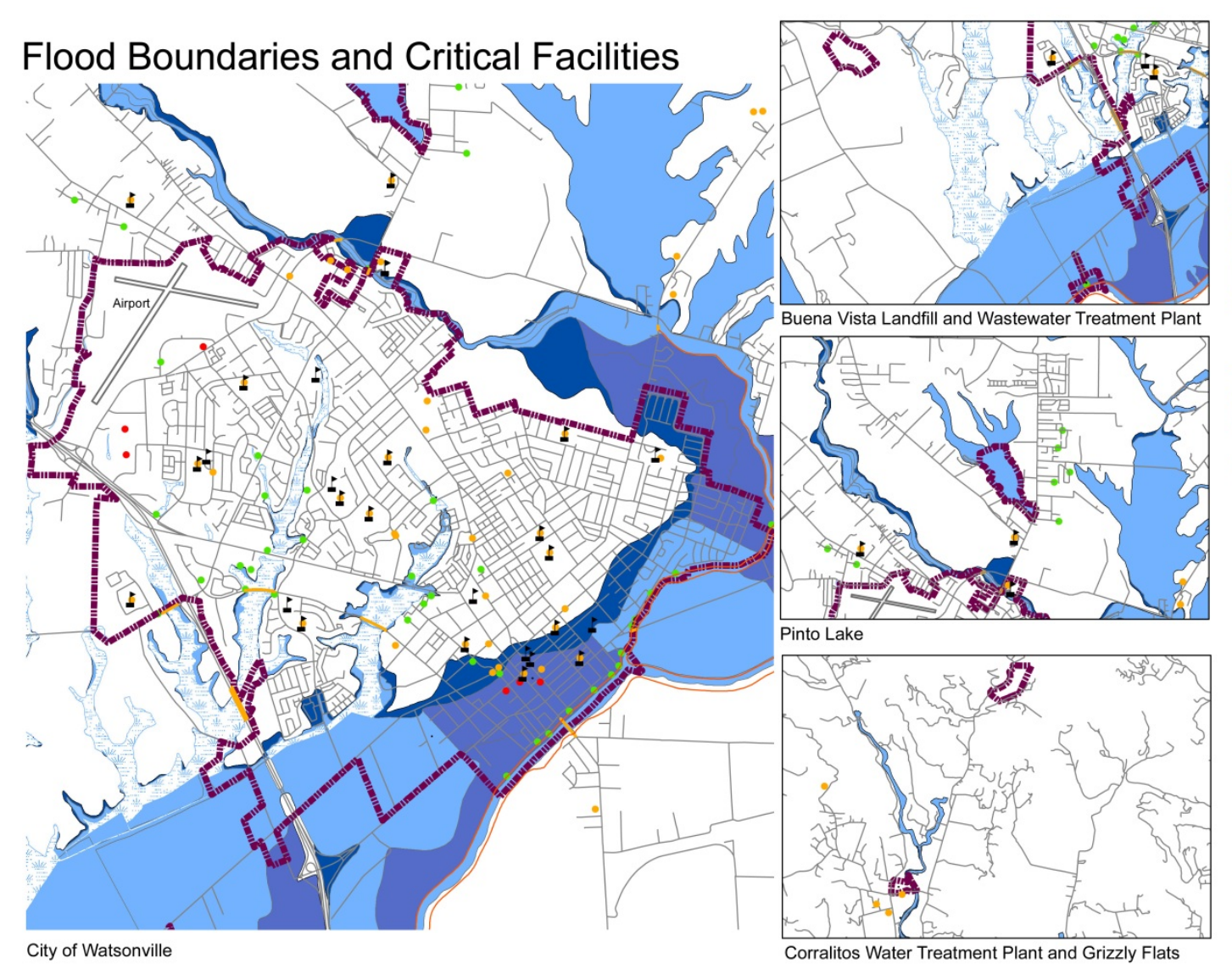

\section{DRAFT}

Flood Hazard

$0.2 \%$ Annual

A99 Area Protected by Constructed Structures A, AE 0.1\% Annual, Depth Not Determined AH, AO 0.1\% Annual, Flooding Depth 1-3 Ft Open Water

VE 0.1\% Annual with Storm Influence $\square \times$ Outside $0.2 \%$ Annual

ISchool Points

-Levees

-Bridges

Watsonville City Limit

- Streets

Sloughs

- Emergency Response

Civic Center

Police Station
Fire Stations

Hospital

- PopulationCenters County Facilities

YMCA, YWCA

Red Cross Shelters
Senior and Special Population Residential Facilities

- Infrastructure

Storm Drain Pumps

Sanitary Sewer Pumps
Transit Center

Transit Center
Airport Runway

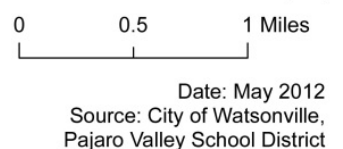




\section{A Location}

City floodplains have been recently mapped by FEMA which administers the National Flood Insurance Program (NFIP). Information about floodplains in the City of Watsonville can be found in FEMA's more recent Flood Insurance Study (FIS) and on the Flood Insurance Rate Maps (FIRM).

Several areas of the City are subject to flooding due to close proximity to the Pajaro River, Salsipuedes Creek, and Corralitos Creek. The Pajaro River and its floodplain run through agricultural lands within the Pajaro Valley, and downstream, through downtown Watsonville. The Pajaro River is a perennial stream that flows through Santa Clara County, San Benito County, and is the dividing line between Santa Cruz County and Monterey County. The downstream portion of the river is channelized with a levee that runs 11.3 miles to Monterey Bay. Monterey and Santa Cruz Counties provide annual maintenance of the levee system; ongoing vegetation and sediment maintenance activities are conducted in order to provide as much flood conveyance capacity as possible, working within environmental regulatory restrictions (Action Pajaro Valley 2012). Harkins, Struve, and Watsonville Sloughs also have a flooding potential and each slough has a regulatory floodplain as mapped by FEMA.

The City of Watsonville, the unincorporated town of Pajaro, and surrounding agriculture areas in Santa Cruz and Monterey Counties are subject to flooding from the Pajaro River. The City of Watsonville and unincorporated areas of Santa Cruz County are also subject to separate and independent flooding from Salsipuedes and Corralitos Creeks.

Watsonville is not located on the coast and thus is not influenced by coastal flooding. However, heavy rains are usually accompanied by strong storm winds combined with high tides that create storm surges. When storms occur simultaneously with high tides, flood conditions at the mouth of the Pajaro River (downstream of the City) are exacerbated. 


\section{B Extent: Magnitude or Severity}

Floods are gauged by their cresting elevation, the area of inundation or damages and either the size of the event or the probability of occurrence. The size and depth of the floodplain area is computed using mathematical models of precipitation, slope, runoff, soil type and crosssection. Flood depths are calculated at intervals along a stream or channel corridor and then mapped and interpolated between sections.

Flood hazard areas identified on the Flood Insurance Rate Map are identified as Special Flood Hazard Areas (SFHA). SFHA are defined as the area that will be inundated by the flood event having a 1-percent chance of being equaled or exceeded in any given year. The 1-percent annual chance flood is also referred to as the base flood or 100-year flood. SFHAs are labeled as Zone A, Zone AO, Zone AH, Zone AE, Zone A99, Zone AR, Zone V, and Zone VE. See Table 3.5-1 for an explanation of these zones. Moderate flood hazard areas, labeled Zone X, are the areas between the limits of the base flood and the 0.2-percentannual-chance (or 500-year) flood. The areas of minimal flood hazard, which are the areas outside the SFHA and higher than the elevation of the 0.2-percent-annual-chance flood, are labeled Zone C or Zone X (County of Santa Cruz 2010). 
Table 3.5-1Special Flood Hazard Areas

\begin{tabular}{|l|l|}
\hline A & $\begin{array}{l}\text { Areas subject to inundation by the 1-percent-annual-chance flood event. Base Flood Elevations or flood } \\
\text { depths not determined. }\end{array}$ \\
\hline AE & $\begin{array}{l}\text { Areas subject to inundation by the 1-percent-annual chance flood event. Base Flood Elevations } \\
\text { determined. }\end{array}$ \\
\hline AH & $\begin{array}{l}\text { Areas subject to inundation by 1-percent-annual-chance shallow flooding (usually areas of ponding) } \\
\text { where average depths are between one and three feet. Base Flood Elevations determined. }\end{array}$ \\
\hline AO & $\begin{array}{l}\text { Areas subject to inundation by 1-percent-annual-chance shallow flooding (usually sheet flow on sloping } \\
\text { terrain) where average depths are between one and three feet. Average flood depths determined. }\end{array}$ \\
\hline AR & $\begin{array}{l}\text { Areas that result from the decertification of a previously accredited flood protection system that is } \\
\text { determined to be in the process of being restored to provide base flood protection. }\end{array}$ \\
\hline A99 & $\begin{array}{l}\text { Areas subject to inundation by the 1-percent-annual-chance flood event, but which will ultimately be } \\
\text { protected upon completion of an under construction Federal flood protection system. These are areas of } \\
\text { special flood hazard where enough progress has been made on the construction of a protection system, } \\
\text { such as dikes, dams, and levees, to consider it complete for insurance rating purposes. }\end{array}$ \\
\hline V & $\begin{array}{l}\text { Areas along coasts subject to inundation by the 1-percent-annual-chance flood event with additional } \\
\text { hazards associated with storm-induced waves. Base Flood Elevations not determined. }\end{array}$ \\
\hline VE & $\begin{array}{l}\text { Areas subject to inundation by the 1-percent-annual-chance flood event with additional hazards due to } \\
\text { storm-induced velocity wave action. Base Flood Elevations determined. }\end{array}$ \\
\hline $\begin{array}{l}\text { X } \\
\text { (Shaded } \\
\text { on } \\
\text { FIRM) }\end{array}$ & $\begin{array}{l}\text { Areas of 0.2-percent-annual-chance flood; areas of 1-percent-annual chance flood with average depths of } \\
\text { less than 1 foot or with drainage areas less than 1 square mile; and areas protected by levees from 1- } \\
\text { percent-annual-chance flood. }\end{array}$ \\
\hline $\begin{array}{l}\text { X (Not } \\
\text { shaded } \\
\text { on } \\
\text { FIRM) }\end{array}$ & $\begin{array}{l}\text { Areas determined to be outside the 0.2-percent-annual-chance flood. } \\
\text { Sour Sal }\end{array}$ \\
\hline
\end{tabular}

Source: Santa Cruz County LHMP

\section{Repetitive Loss Properties}

FEMA records indicate that the City of Watsonville currently has 79 repetitive loss properties, which are

NFIP-insured structures that have had at least two paid flood losses of more than $\$ 1,000$ each in any 10 year period since 1978. Flood insurance claim payments on these properties alone total over $\$ 704,300$ dollars. The City of Watsonville is classified as a Category C Repetitive Loss Community under the Community Rating System (CRS). Category C Communities are those with more than 10 repetitive loss properties (National Flood Insurance Program 2011). 


\section{Previous Occurrences}

Due to the proximity to several waterways, the City of Watsonville has experienced several flooding events over the past half-century. Below is a discussion of previous flooding events (Action Pajaro Valley 2012, FEMA 2006).

1942: Severe winter storms caused the Pajaro River and Corralitos Creek to overflow and significantly flood surrounding areas.

1955: Severe winter storms in December caused the Pajaro River and Corralitos Creek to overflow and significantly flood surrounding areas. During this storm event, 24,000 cfs were discharged from the Pajaro River. The river was maintained within the levees in the Watsonville area but levees were breached on the Corralitos Creek 2.1 miles upstream of the confluence with Salsipuedes Creek. Approximately 29 blocks were flooded within the City at a maximum depth of 2 feet. Flooding of this magnitude has a reoccurrence probability of 27 years. There were no fatalities, although 972 people were evacuated and there was $\$ 1.12$ million in damages. This amount includes funds necessary for reconstruction to levees damaged by erosion. This was the first major flooding event to breach the levees since their construction in 1949.

1958: Flooding during April of 1958 caused the Pajaro River to flood and discharge 23,500 cfs of water. Flooding of this magnitude has a reoccurrence probability of 26 years. Levees were damaged by erosion during the flooding and required reconstruction, although there was limited additional damage.

1975: Severe winter storms caused the Pajaro River and Corralitos Creek to overflow and significantly flood surrounding areas. 
1982: Severe winter storms caused the Pajaro River and Corralitos and Salsipuedes Creeks to overflow and flood surrounding areas. The levees were breached and required repairs. Flooding from the Corralitos Creek caused shallow flooding 200-1,000 feet wide at Bridge Street and Riverside Drive. Homes adjacent to Salsipuedes Creek near the eastern end of Tuttle Ave were damaged. The Pajaro Valley suffered minor damage due to flooding.

1986: Severe winter storms caused the Pajaro River and Corralitos and Salsipuedes Creeks to overflow and significantly flood surrounding areas. The Loma Prieta Earthquake caused significant levee damage.

1994: Severe winter storms caused the Pajaro River and Corralitos Creek to overflow and flood surrounding areas.

1995: Severe winter storms caused the Pajaro River and Corralitos Creek to overflow, breach levees, and flood 3,280 acres. Agricultural crop damages were estimated at \$67 million dollars and in the unincorporated town of Pajaro, damages were estimated at \$28 million dollars. Flooding occurred at less than channel design capacity.

1997: Flooding occurred along the Corralitos Creek.

1998: February 1998 flooding occurred downstream of the urban areas of Watsonville and approximately \$1.7 million in agricultural crop damages and \$ 0.4 million in non-crop damages occurred. These agricultural damages are considered to be low considering 800 of the 1,100 flooded acres were in the preparation phase and without established plantings. 


\section{E Probability of Future Events}

The probability of occurrence is expressed in a percentage of the chance of a flood of a specific extent occurring in any given year. The most widely adopted design and regulatory standard for floods in the United States is the 1-percent annual chance flood, and this is the standard formally adopted by FEMA. The 1-percent annual flood is also commonly referred to as the " 100 -year flood," leading to the misconception that it should occur only once every 100 years. In fact, a 100-year flood may occur in any year, regardless of the time that has passed since the last one. It is the probability that smaller floods occur more often than larger floods that compels the percentage.

Significant storms and associated damage from flooding strike the Monterey Bay communities with a frequency of one large storm every three to four years. A 100-year flood has a one percent probability of occurring in any given year and while considered to be a severe flood, it still has a reasonable possibility of regular occurrence. For the purposes of the protection of property, life and safety, floods of other magnitudes and occurrence intervals should also be considered in mitigation efforts.

The potential magnitude of flooding for each major waterway in Watsonville is presented in Table 3.5-2. 
Table 3.5-2 Drainage Areas for Corralitos Creek, Salsipuedes Creek, and Pajaro River

\begin{tabular}{|l|l|l|l|l|l|}
\hline Location & $\begin{array}{l}\text { Drainage Area } \\
\text { (in square } \\
\text { miles) }\end{array}$ & $\begin{array}{l}\text { 10-Year Flood } \\
\text { Event }\end{array}$ & $\begin{array}{l}\text { 50-Year Flood } \\
\text { Event }\end{array}$ & $\begin{array}{l}\text { 100-Year Flood } \\
\text { Event }\end{array}$ & $\begin{array}{l}\text { 500-Year Flood } \\
\text { Event }\end{array}$ \\
\hline $\begin{array}{l}\text { Corralitos Creek } \\
\text { (above the } \\
\text { confluence with } \\
\text { Browns Creek) }\end{array}$ & 11 square miles & $2,030 \mathrm{cfs}$ & $4,040 \mathrm{cfs}$ & $5,040 \mathrm{cfs}$ & $7,550 \mathrm{cfs}$ \\
\hline $\begin{array}{l}\text { Corralitos Creek } \\
\text { (at the junction } \\
\text { with Salsipuedes } \\
\text { Creek) }\end{array}$ & $\begin{array}{l}24.2 \text { square } \\
\text { miles }\end{array}$ & $3,300 \mathrm{cfs}$ & $6,640 \mathrm{cfs}$ & $7,930 \mathrm{cfs}$ & $11,730 \mathrm{cfs}$ \\
\hline $\begin{array}{l}\text { Pajaro River } \\
\text { (downstream of } \\
\text { the confluence } \\
\text { with Salsipuedes } \\
\text { Creek) }\end{array}$ & $\begin{array}{l}1,275 \text { square } \\
\text { miles }\end{array}$ & $14,250 \mathrm{cfs}$ & $32,500 \mathrm{cfs}$ & $43,600 \mathrm{cfs}$ & $76,200 \mathrm{cfs}$ \\
\hline $\begin{array}{l}\text { Salsipuedes } \\
\text { Creek (at the } \\
\text { confluence with } \\
\text { the Pajaro River) }\end{array}$ & $\begin{array}{l}46.0 \text { square } \\
\text { miles }\end{array}$ & $2,000 \mathrm{cfs}^{1}$ & $4,500 \mathrm{cfs}^{1}$ & $5,950 \mathrm{cfs}^{1}$ & $12,500 \mathrm{cfs}^{1}$ \\
\hline
\end{tabular}

${ }^{1}$ Discharge loss downstream of the Corralitos Creek occurs as individual overbank flow.

Source: FEMA 2006

\section{F Climate Change Considerations}

Storm events and flooding are closely related to climate and thus flooding will be impacted by climate change. It is anticipated that climate change will impact the frequency and severity of storm events; storm events may occur more or less frequently than they currently do, and will most likely be more severe. With climate change, it is possible that an increase of storms will increase the frequency and severity of flooding.

Climate change may also induce sea level rise which could impact the city by raising water levels in the Pajaro River and thus increasing the incidence of flooding and could impact the wastewater treatment plan which is outside of the city and closer to the coast. 


\section{G Vulnerability Assessment}

Riverine flooding and levee failure are risks for much of the downtown and many residential areas of the City. Many residences and critical facilities have been built within flood-prone areas and properly protecting these structures from flooding is essential to preventing loss of human life and protecting the local economy. Flooding may occur independent of levee failure, but there is also a threat of flooding due to levee failure.

\section{H Summary of Protection Measures and Future Vulnerability}

Flood protection measures have included both structural and nonstructural measures. Structural measures have included levee construction along the Pajaro River and Salsipuedes Creek and structure elevation measures. However these levees are currently not designed to protect against a larger flooding event and may be damaged in an earthquake regardless of the water level. Nonstructural measures include floodplain zoning ordinances that regulate building within the floodplain as well as protection of riparian areas that further limit impacts of flooding on structures.

\section{Impact of Hazards}

Flooding in the various river basins impact public health and safety, critical facilities and infrastructure,and the community's economy. When floods hit the community, as shown by the past history, public health and safety issues (including loss of life and property as well as the overall health of the community) can be widespread. Recognition of these hazards has led the City of Watsonville to work 
with the U.S. Army Corps of Engineers in recent years to develop a plan to improve levee safety. Additionally, the County of Santa Cruz has improved rain and stream gauging in the Corralitos Creek and Pajaro River watersheds. The improved gauging includes real-time monitoring of rainfall and stream levels that are monitored 24 hours a day during storm events.

This monitoring is coordinated with the County Public Works Department, the County Emergency Operations Center, the National Weather Service in Monterey, NOAA, and the USGS. In the Pajaro River watershed, monitoring coordination also includes the Santa Clara Water District, and the counties of San Benito and Monterey. Close coordination has allowed an alert system to be developed through the use of a reverse 911 system. This system may not save fixed structures, but it can save lives. Coordination with other agencies has also helped to time releases from reservoirs (San Benito County Water District, Pajaro Valley Water Management Agency, Santa Clara Valley Water District 2007) so that releases do not coincide with peak flows.

\section{J Types and Numbers of Existing Buildings, Facilities, and Infrastructure}

Several bridges intersect Watsonville and are necessary for travel through the city. Flooding events could close bridges if the bridge is close or below the flood crest. Much of the downtown is within an area with the potential for flooding and several critical facilities are located within this flooding area.

Several critical facilities are within the 100-year floodplain which could experience a depth of 1-3 feet of water. These facilities include the civic plaza, police headquarters and fire station \#1 as well as several water pumping facilities. This depth of water may not exclude use of the facility, but it may impact use and hinder city operation and emergency response. 
Several daycares and historic sites are within the 100 and 200 -year floodplain. Many historic sites in the floodplain could be impacted by a 100-year flood with a water depth of 1-3 feet. This amount of water may critically impact historic structures due to weakened or older building materials once water has receded, which creates a higher vulnerability for historic structures than to other structures.

\section{Figure 3.5-2 Flood Areas and Daycare Facilities}

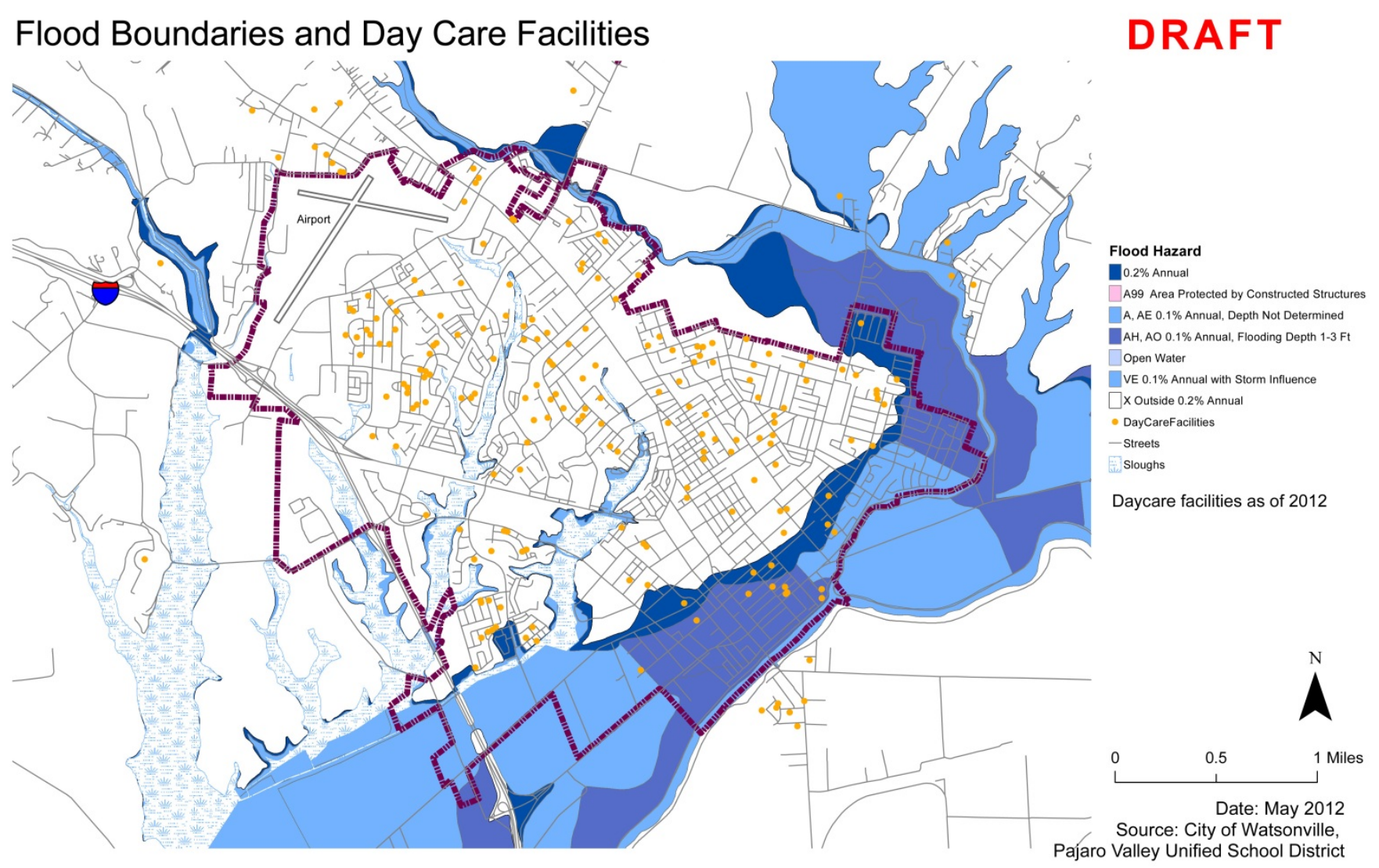


Figure 3.5-3 Flood Areas and Historic Properties

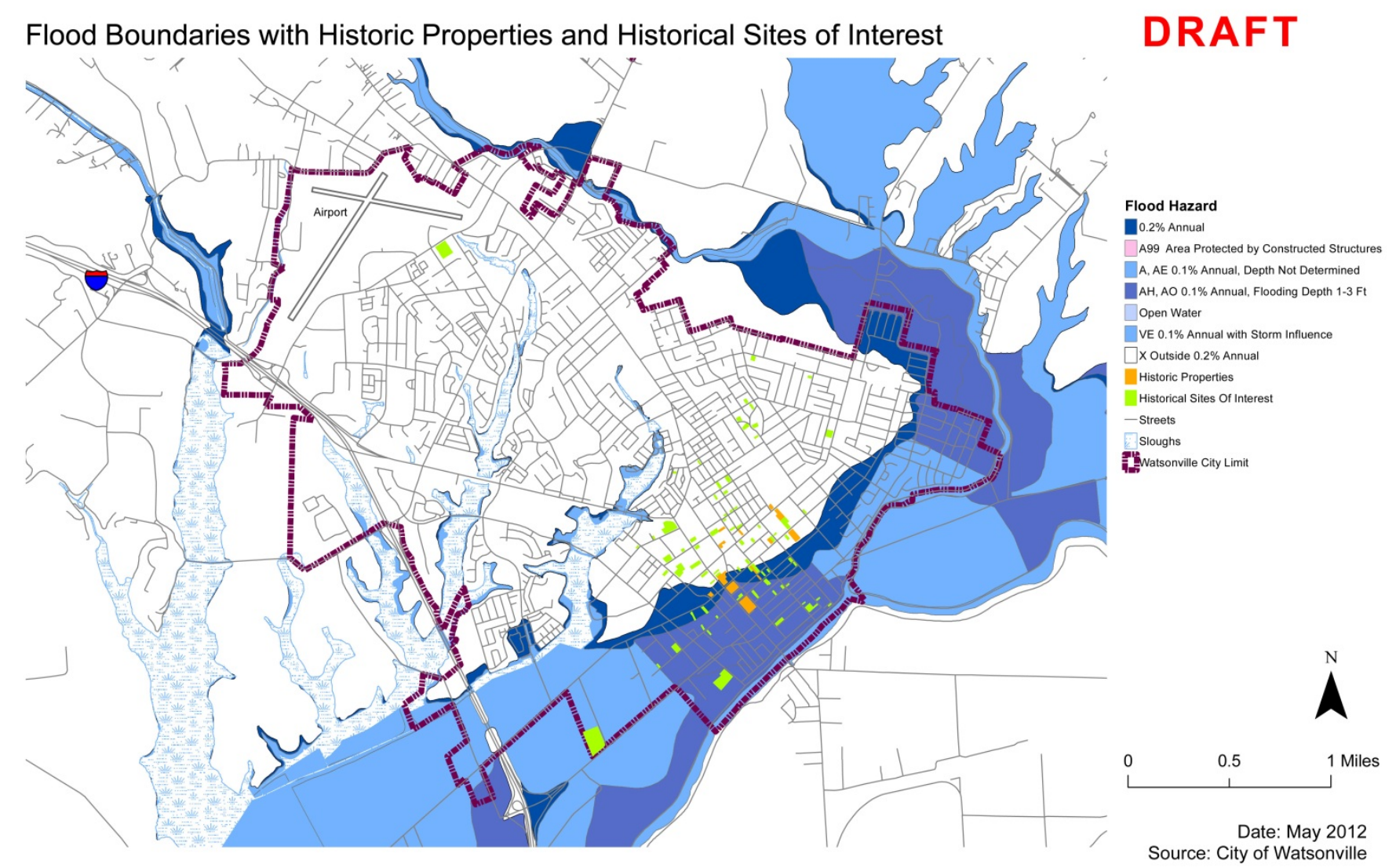

\section{K Description of Land-Uses and Development Trends}

As with most communities, increased housing costs have resulted in the need to provide higher density housing and affordable housing. Anticipated growth will occur in areas where urban services are available and additional development will be infill, reuse, and development of existing residential properties. Infill development may occur in areas that currently have a flood risk although new development within the urban limit lines established by Measure U will not occur within the floodplain area at the northern area of the City. However, additional development will increase the population vulnerable to flooding. 


\subsection{Hazardous Materials Profile}

Hazardous materials are substances that are flammable, combustible, explosive, toxic, noxious, corrosive, an oxidizer, an irritant, or radioactive. A hazardous materials spill or release can pose a risk to life, health or property. An incident can result in the evacuation of a few people, a section of a facility, or an entire neighborhood (California Emergency Management Agency 2010).

Hazardous materials may pose a significant risk to the environment or human health and safety if spilled or released. These materials may present a risk due to the quantity, concentration or physical or chemical characteristics of the material. The nature of the materials or type of release or spill event may determine the method or severity of a hazardous materials emergency event. While a hazardous materials spill or release may be due to human error, hazardous material spills may be caused by natural hazards, such as earthquakes, fires or floods.

Most of the hazardous materials stored or utilized in Santa Cruz County are within the City of Watsonville and are used for cold storage or for water treatment. Ammonia and chlorine gas are the most common hazardous materials within the city, although there are smaller concentrations of methyl bromide, a common pesticide (City of Watsonville 2012a). The County regulates extremely or acutely hazardous substances, although lesser hazardous substances may also be present within the City. 


\section{A Location}

High concentrations of hazardous materials are found within Watsonville relating to the industrial activity of the City. Chlorine gas used at water wells is also located throughout the City. Each location with hazardous materials has the potential for human error or for natural hazards, such as earthquakes and floods, to cause a hazardous materials spill or release.

\section{B Extent: Magnitude or Severity}

Magnitude and severity of a hazardous materials spill or release is dependent upon the type of material released, the amount released or spilled, the method of release, and the climatic conditions at the time of the release or spill. Fog conditions, which are common in Watsonville, would exacerbate the effects of a hazardous gas release by preventing dissolution of the gas.

\section{Previous Occurrences}

Hazardous materials leaks or spills are not uncommon in the City of Watsonville, particularly because of the concentration of industrial materials and activity within the City.

During the 1989 Loma Prieta earthquake, there were several hazardous materials incidents, including a number of ammonia leaks. There were also several incidents of chemicals spilling and mixing at pharmacies and medical clinics. There were no issues from the two pesticide storage facilities that were in the City at the time due to proper storage and separation of chemicals. (City of Watsonville 1990) 
Small sewage and petroleum spills are not uncommon in Watsonville, but the City does not experience an abnormally high number of such spills. Spills or releases of more dangerous hazardous materials have occurred in the City. Hazardous material release events of chemicals (other than petroleum) from the past ten years are listed below.

Table 3.6-1 Previous Events of Chemical Material Releases, 2002-2012

\begin{tabular}{|c|c|c|c|c|}
\hline Date & Location & Chemical & Amount & Description \\
\hline September 29, 2007 & 555 Walker St & Ammonia & 5 Gallons & $\begin{array}{l}\text { Accidental release } \\
\text { while chemicals } \\
\text { were mixed }\end{array}$ \\
\hline November 6, 2011 & 1720 West Beach St & $\begin{array}{l}\text { Anhydrous } \\
\text { Ammonia }\end{array}$ & 1 Gallon & $\begin{array}{l}\text { Release occurred } \\
\text { from a packing nut } \\
\text { due to a power } \\
\text { failure which created } \\
\text { a pressure build up. }\end{array}$ \\
\hline July 21, 2011 & 1720 West Beach St & $\begin{array}{l}\text { Anhydrous } \\
\text { Ammonia }\end{array}$ & Unknown & $\begin{array}{l}\text { Substance was } \\
\text { released due to a } \\
\text { leaking valve. }\end{array}$ \\
\hline April 6, 2009 & 555 Walker St & Ammonia & 25 Pounds Vapor & $\begin{array}{l}\text { Release occurred } \\
\text { during maintenance. }\end{array}$ \\
\hline February 4, 2007 & 1720 West Beach St & $\begin{array}{l}\text { Anhydrous } \\
\text { Ammonia }\end{array}$ & 10 Pounds Vapor & $\begin{array}{l}\text { Release occurred } \\
\text { due to the failure of } \\
\text { a mechanical seal. }\end{array}$ \\
\hline May 1, 2006 & $\begin{array}{l}\text { Watsonville } \\
\text { Railyard Junction }\end{array}$ & Propane & Unknown & $\begin{array}{l}\text { Release occurred } \\
\text { due to a broken seal } \\
\text { on a rail car. }\end{array}$ \\
\hline July 1, 2011 & 1720 West Beach St & $\begin{array}{l}\text { Anhydrous } \\
\text { Ammonia }\end{array}$ & 1 Gallon & $\begin{array}{l}\text { Release due to } \\
\text { failure of a } \\
\text { mechanical shaft. }\end{array}$ \\
\hline
\end{tabular}

Source: CalEMA Hazardous Materials Spills Database

\section{Probability of Future Events}

The probability of future hazardous materials release events is based on the amount of hazardous materials present and the safety precautions taken when handling such materials. The probability of hazardous materials release events is not anticipated to change significantly in the near future, assuming that there will not be a significant change in the type or quantities of hazardous materials. Based on previous occurrences, the current probability of a significant and hazardous release of hazardous materials 
is low, due to the limited number of even small amounts of hazardous materials. However, the probability still remains for a large release to occur based on the large quantities of hazardous materials in the City.

\section{E Climate Change Considerations}

Hazardous materials releases are not influenced by climate and thus it is not anticipated that climate change will influence the risk of hazardous materials releases or spills.

\section{F Vulnerability Assessment}

Vulnerability to hazardous materials is dependent upon the presence and type of hazardous materials and the storage and regulation of such materials. Watsonville has a relatively high concentration of hazardous materials related to industrial activities.

There are several protection measures in place regarding hazardous materials. Hazardous materials are closely regulated by the County Department of Public Health and the location, quantity, and type of each material is registered with the County.

\section{G Types and Numbers of Existing Buildings, Facilities, and Infrastructure}

The release of hazardous materials is not likely to have a significant impact on structures or infrastructure, but would instead impact the public health and safety by contaminating air or water resources. 


\section{H Description of Land-Uses and Development Trends}

As with many communities, the City of Watsonville is striving to address increased housing costs which has resulted in the need to provide higher density housing and affordable housing. The increase of housing is indented to address present needs as well as future growth projections. Anticipated growth will occur in areas not currently built out and additional development will be infill, reuse, and increased development on existing residential properties.

The vulnerability of the present and future population will be dependent upon the proximity of these populations to hazardous materials as well as the future amounts and types of materials present in the city. Although intense expansion of the City's industrial economy is not anticipated, such an expansion would likely increase the amounts and types of materials present and would increase the vulnerability of the City to hazardous materials. An increase of the population without an increase in hazardous materials would not increase the vulnerability of the city to hazardous materials, however a large release or spill would have the potential to affect a greater number of people.

\subsection{Liquefaction Profile}

Liquefaction is the transformation of loose, water-saturated granular materials from a solid to a liquid state. Liquefaction occurs in saturated soils, which are soils in which the space between individual particles is completely filled with water. The water exerts a pressure on the soil particles that influences how tightly the particles themselves are pressed together. Prior to an earthquake, the water pressure is relatively low. Shaking during an earthquake can cause the water pressure to increase to the point where the soil particles can readily move with respect to each other. When liquefaction occurs, the strength of the soil decreases and the ability of the soil to support structure foundations is reduced and can lead to 
ground failure (City of Santa Cruz 2007). Ground failure can result in the collapse of buildings built on liquefied soils. Liquefaction was a significant cause of damage in Watsonville during the 1989 Loma Prieta earthquake.

Figure 3.7-1 Liquefaction Areas

\section{Liquefaction Potential and Critical Facilities}

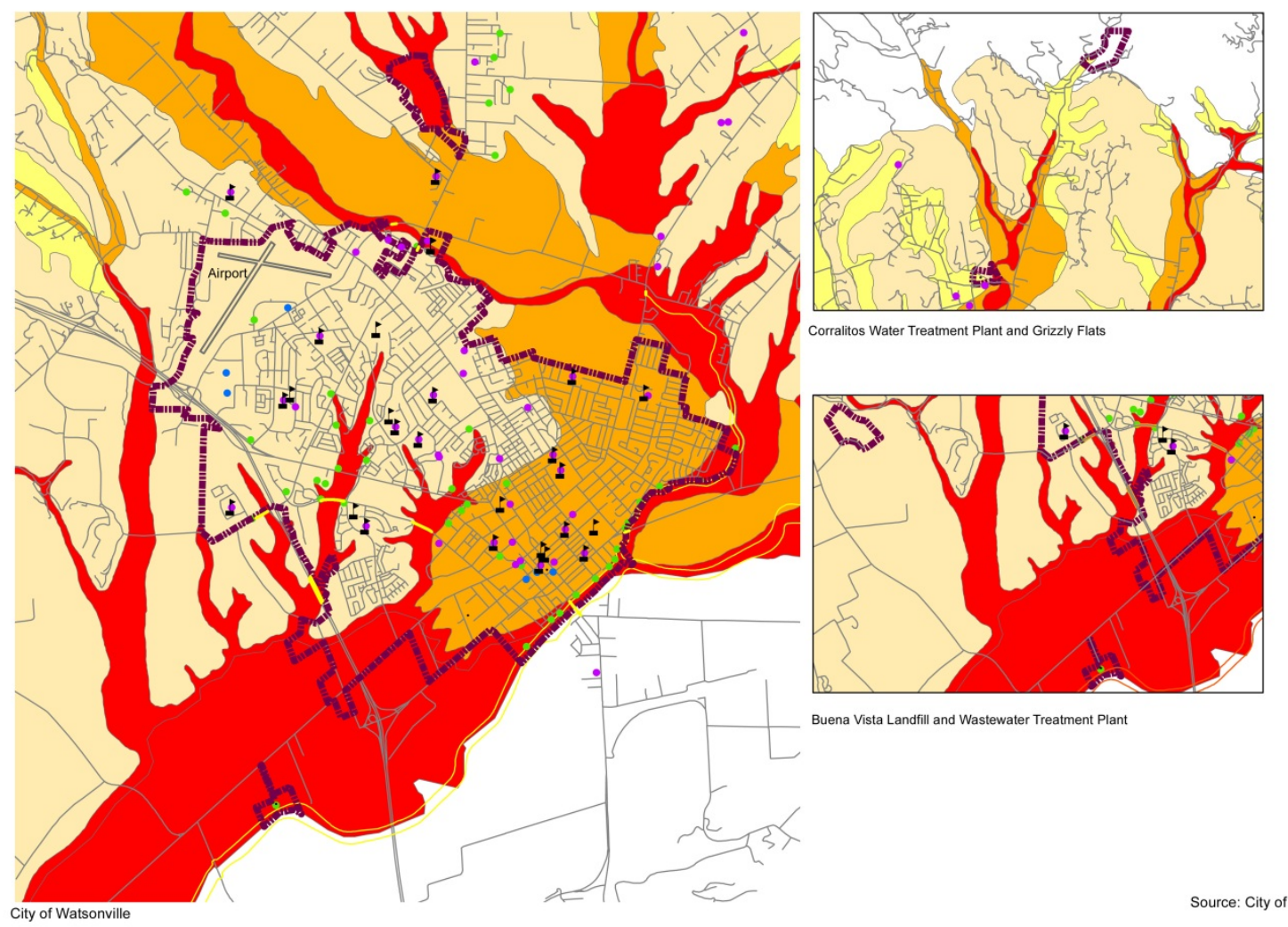

DRAFT

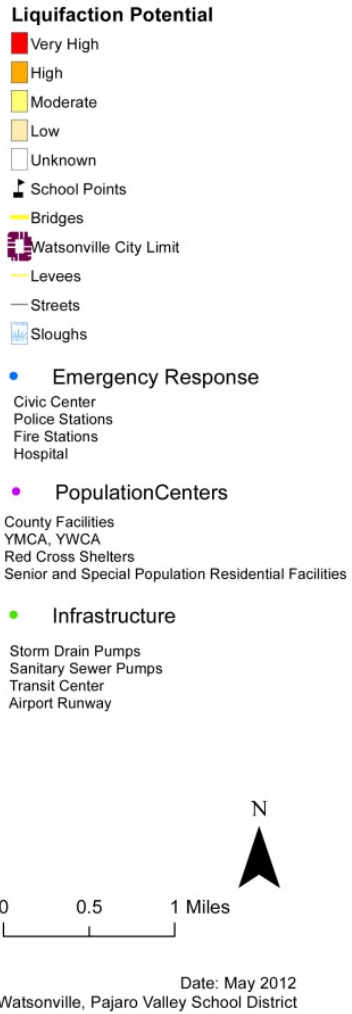

\section{A Location}

Low laying coastal areas and floodplain areas are generally susceptible to soils with a liquefaction potential. Many soils within the City have the potential for liquefaction in the event of an earthquake. Additionally, the City is vulnerable to earthquakes which cause liquefaction. 


\section{B Extent: Magnitude and Severity}

The magnitude or severity of liquefaction in the City of Watsonville is directly related to the seismic risk of the City. The larger a potential event is, the greater the probability that the earthquake would cause liquefaction in the City. Minor seismic activity is not likely to cause liquefaction issues. Similarly, the closer seismic activity is to the City, the greater the potential for it to cause liquefaction. Thus there is less of a risk of liquefaction if seismic activity is of a minor magnitude further from Watsonville, and a greater risk of liquefaction if seismic activity is of a higher magnitude along faults closest to the City. As discussed in an earlier section, there is a moderate probability of a high magnitude earthquake to effect the city.

\section{Previous Occurrences}

Liquefaction in the Watsonville area was documented during the 1906 San Francisco earthquake and the 1989 Loma Prieta earthquake. During the 1989 earthquake, liquefaction in the area was characterized by sand boils and a 1.7 km-long lateral spread north of the Salsipuedes Creek and Pajaro River confluence (County of Santa Cruz, County of Monterey, U.S. Army Corps of Engineers 2011).

A report after the 1989 Loma Prieta earthquake identified that most of the damage in the City was where soils had liquefied during the earthquake (City of Watsonville 1990). Due to the seismic history of the area, and the type of soils present, it is likely that liquefaction has occurred previous to 1909, although there are no specific reports. 


\section{Probability of Future Events}

Due to the presence of liquefaction soils in the City, and the high potential for seismic activity, there is a potential for liquefaction to occur in the City of Watsonville. This probability is directly related to the magnitude and frequency potential for seismic activity.

\section{E Climate Change Considerations}

Liquefaction is directly related to seismic activity. As seismic activity is not influenced by climate, it is not anticipated that liquefaction occurrence or severity will be influenced by climate change.

\section{F Vulnerability Assessment}

The vulnerability of the city to liquefaction is based on several factors including the presence of soils with a liquefaction potential, the probability of large earthquake events, the age of structures in the city and the density of the population.

Liquefaction soils are present throughout the City and have the potential to liquefy during large seismic events. Although there are different levels of liquefaction potential in different areas of the City, most of the City has either a moderate to very high potential for liquefaction. Additionally, a number of structures in the City are older and were not built to current building standards. 


\section{G Types and Numbers of Existing Buildings, Facilities, and Infrastructure}

Liquefaction would affect both aboveground facilities and infrastructure and underground infrastructure. Building codes do not commonly address liquefaction potential and thus many structures, even those built to current standards, could easily be damaged in the event of liquefaction. Underground infrastructure such as water and natural gas infrastructure, would be damaged due to the loss of foundational support.

Most soils in the city have a liquefaction potential and thus critical facilities and infrastructure within the City are vulnerable.

As seen in Figure 3.7-1, the areas with a very high potential to liquefy closely follow slough and river areas and are not extensively built upon. However many of the bridges in the city are built in very high potential zones and represent a critical vulnerability in emergency service and evacuation. Much of the downtown has a high potential for liquefaction. Specifically, there are 7 identified special population facilities, 12 Red Cross and school facilities, as well as the Civic Plaza, Fire Station 1, and Police Headquarters are in areas with a high potential for liquefaction.

\section{H Description of Land-Uses and Development Trends}

Infill development would increase the number of people that could be impacted by liquefaction, and the increased density would make a greater number of people vulnerable. New development of areas subject to liquefaction would similarly create a vulnerability to a greater number of people, although if these areas are developed to a lesser density, single significant damages would likely affect a lesser number of people thus decreasing the vulnerability of liquefaction. The area within the 20-year Urban Limit Line 
established by Measure $U$ has primarily soils with a low potential for liquefaction and some areas in the east (within the 25-year Urban Limit Line) have soils with a high potential for liquefaction. It is likely that increased development will increase the vulnerability to liquefaction.

\subsection{Land Subsidence Profile}

Subsidence is the deformation of the ground caused by shallow groundwater withdrawl, decomposition of underlying organic peat soils, and/or the sustained weight of ponded water over these areas (County of Santa Cruz 2003). In Watsonville, land subsidence has contributed to reduced water circulation and could potentially damage levees and underground infrastructure. Pipelines or underground infrastructure subject to significant ground displacement may develop leaks or breaks (California Emergency Management Agency 2010). Subsidence in Watsonville has primarily occurred due to groundwater withdrawl for agriculture operations.

\section{A Location}

Subsidence in the Watsonville area has been in small areas, and thorough mapping of potential subsidence hazards has not been undertaken. Thus, although subsidence may continue to occur within the City, precise locations cannot be anticipated at this time.

\section{B Extent: Magnitude or Severity}


Subsidence events in the City have been relatively minor. It is not anticipated that future events will be severe or affect a large number of facilities or structures.

\section{Previous Occurrences}

The Watsonville Slough Conservation Enhancement Plan identified an area near Ford Street that experienced subsidence. Any other occurrences of subsidence are currently unknown.

\section{Probability of Future Events}

The probability of continued land subsidence is difficult to establish due to the lack of data of existing subsidence occurrences, and the potential for several factors to influence the potential hazard. Overdraft of groundwater is a concern in the City and if extensive overdraft occurs, there may be an increased potential for land subsidence in the City.

\section{E Climate Change Considerations}

The risk of subsidence to the city is not anticipated to change due to climate change. The current factors which may impact subsidence in the city are not presently determined. Thus it cannot be determined if those factors will be influenced by climate change. An impact due to climate change is not currently anticipated. 


\section{F Vulnerability Assessment}

Vulnerability of the City to subsidence is based on existing subsidence, future overdraft of groundwater, and various soil types. Existing occurrences of subsidence in the city is not well understood and additional factors may influence future instances of subsidence. Subsidence has the potential to affect structures and facilities, and above and underground infrastructure.

\section{G Types and Numbers of Existing Buildings, Facilities, and Infrastructure}

Existing subsidence has not occurred in the close proximity to critical facilities or infrastructure. Greater investigation of potential subsidence occurrences may identify additional vulnerabilities to the City.

\section{H Description of Land-Uses and Development Trends}

The vulnerability of the present and future population will be dependent upon the proximity of these populations to areas of potential subsidence.

\subsection{Landslide Profile}

Landsliding is a general term for a variety of mass downslope movements of soil and rock. Landsliding may occur as falls, topples, slides, spreads, flows or a combination of these and may change from one failure type to another during movement. Landslides may be impacted by rock strength and orientation of elements, erosion, weathering, rainfall, slope, seismic activity, and human activities. In Watsonville, 
landsliding can be caused by storms, earthquakes, fires, erosion or vegetation removal or other human activities.

\section{Figure 3.9-1 Sloped Soils}

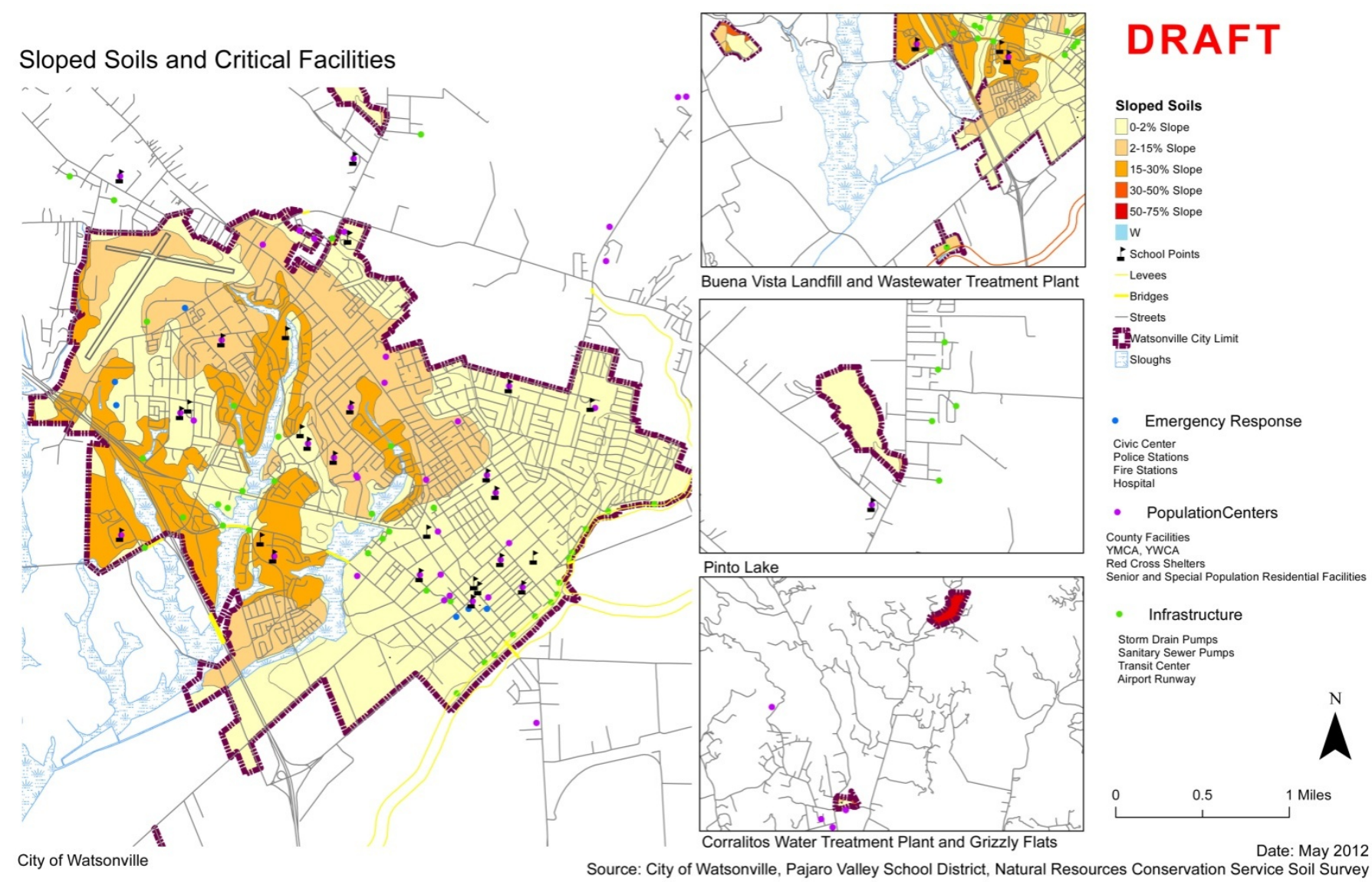

\section{A Location}

The City of Watsonville is not representative of the slopes found throughout the county however there are some sloped areas within the city. Generally the slopes in the City are slight; most slopes are less than $30 \%$ and those that are greater than $30 \%$, are located adjacent to sloughs. There are some areas that could experience a landslide or mudslide if particular conditions were to occur. The Grizzly Flats area to the 
north of the City includes slopes of up to $75 \%$ and has a higher potential for landsliding than most of the slopes in the City.

\section{B Extent: Magnitude or Severity}

Landslides in the city have been minor, affecting single residences or sites rather than large areas of the city. Potential landslides will likely be minor in scale, but may still have a significant impact depending on the location. Even a small landslide adjacent to a roadway may have a very large impact to city operation if roads are impassible due to ground failure.Landsliding adjacent to the airport may also have a similarly severe impact on the City. Thus, while the magnitude of area landslides is likely to be low, the severity of landsliding is dependent upon the location. Further discussion can be found in the vulnerability assessment.

\section{Previous Occurrences}

Past landslides in the city have been minor. Over the past 30 years several residences and the backyards of several homes located in housing developments east of Green Valley Road and adjacent to Struve Slough have experienced landslides. These landslides may be attributed to poorly constructed retaining walls and fills. Green Valley Road adjacent to Struve Slough has slid and was closed for repairs during the late 1980’s.

\section{Probability of Future Events}

City policies and building codes reduce the potential for landslides within the City. However, landsliding will likely continue to have minor affects in the City of Watsonville. El Nino weather patterns and the 
many fault lines in the region will both continue to contribute to the formation of landslides, although the probability of landsliding is low(County of Santa Cruz 2010).

\section{E Climate Change Considerations}

Soil stability is influenced by storm events which in turn are dependent upon climate. Climate change is likely to impact storm events and may cause more frequent or more severe storm events which could increase the potential for landsliding in the City. Landslides are still likely to be minor in magnitude, but may be more frequent. Severity will continue to be dependent upon location of the landsliding.

\section{F Vulnerability Assessment}

The terrain, weather, and seismicity of the City increase the likelihood of landsliding.Past events have shown that the City is currently will continue to be susceptible to landslides. Most of the damage caused by landslides will likely effect privately owned structures although city roads are also vulnerable to landslides.

\section{G Types and Numbers of Existing Buildings, Facilities, and Infrastructure}

Homes built before 1989 are particularly vulnerable to landslides as some of these were constructed without the benefit of engineering geologic investigations. Most of the city roadways were constructed many years ago with little consideration to slope stability, and may be affected by landsliding in the 
future. Because utilities follow these roads, damage to roads will often disrupt sewers, water systems, gas and electricity, and cable and telephone utilities. Should slopes adjacent to the airport experience landsliding, the structural integrity of the airport would be compromised.

More specific vulnerability to landsliding cannot be determined without site-specific information.

\section{H Description of Land-Uses and Development Trends}

As demand for housing increases, residential construction will spread into existing undeveloped areas with varying slope types. This construction will increase the potential for landslides to occur and increase the vulnerability of the City to landsliding. Infill development may increase the City's vulnerability to landslides if infill is built on existing slopes. The vulnerability of new structures to landslides is likely to be mitigated by superior building standards and practices.

\subsection{Unreinforced Masonry Buildings Profile}

Unreinforced masonry buildings are structures built without steel bars reinforcing masonry building material.In the event of an earthquake, unreinforced masonry buildings (URM buildings) have a greater potential to lose their structural integrity and collapse and in doing so cause injuries or fatalities to inhabitants. The potential for structural collapse during an earthquake increases the likelihood for injuries and fatalities, property loss, and loss of use. This risk is increased by the presence of soils with liquefaction-potential; if the soil under a building has the potential to fail, the greater the potential for the building to fail as well. 
In 1986 the State passed Senate Bill 547 which required each jurisdiction in the state vulnerable to severe earthquakes to complete an inventory of unreinforced masonry buildings, place signage on URM buildings to notify inhabitants of the safety risk, and to develop a retrofit program to reduce the number of URM buildings. The City of Watsonville has completed each of these steps, however the current retrofit program is voluntary, and does not provide incentives or mandatory compliance.

\section{A Location}

Unreinforced masonry is commonly found in older buildings and is found throughout the City of Watsonville. A number of unreinforced masonry buildings collapsed during the 1989 Loma Prieta earthquake and were destroyed, however, there are six unreinforced masonry structures currently within the City. The City has complied with State law which requires signage to be posted on the exterior of each unreinforced masonry building to inform those entering the building of the risk.

(Additional information on the location and use of existing URM structures is pending a review of the current list by the Building Department)

\section{B Extent: Magnitude and Severity}

The magnitude and severity of the collapse of an unreinforced masonry building is determined by the individual building. Although structures where an assembly of people may gather present a greater potential for injury or fatalities, smaller structures may have just as severe an impact in the event of structure collapse.A partial collapse of an unreinforced masonry building will likely result in the complete 
destruction of the building. Further discussion of the risk severity is conducted in the vulnerability assessment.

\section{Previous Occurrences}

During the 1989 Loma Prieta earthquake, approximately 90\% of the damaged structures in the City of Watsonville was due to the collapse of unreinforced masonry buildings and wood frame buildings not properly fastened to the building foundation. Of the 76 businesses that were in unreinforced masonry buildings during the earthquake, approximately 40 were lost (City of Watsonville 1990). It is reasonable to project that earlier earthquakes resulted in the collapse of a significant number of structures due to building techniques without reinforced masonry.

\section{Probability of Future Events}

Due to the presence of unreinforced masonry buildings in the City, there is a probability that in the event of a large magnitude earthquake, existing URM buildings could collapse. The probability of higher magnitude earthquakes increases this risk.

\section{E Climate Change Considerations}

Unreinforced masonry building collapse is directly related to seismic activity. As seismic activity is not

influenced by climate, it is not anticipated that unreinforced masonry building collapse will be influenced by climate change. 


\section{F Vulnerability Assessment}

Vulnerability to the city of URM structures is related to the use of the structure. If there are unreinforced masonry high-occupancy, or assembly structures, the risk to a greater number of lives will be higher than if the URM buildings are storage or infrequently-occupied buildings. However, every URM structure has a higher potential to collapse and each structure is vulnerable to cause injury or loss of life.

\section{G Types and Numbers of Existing Buildings, Facilities, and Infrastructure}

Vulnerability of the City to the collapse of unreinforced masonry buildings is based on the number, location, and condition of such structures in the city. A current inventory of URM structures in the city found six existing structures. The city has shown progress with the retrofit or destruction of URM buildings and the current inventory is much lower than in the past. However, each of these structures present individual vulnerabilities to the city and should be addressed through retrofits or replacement.

Table 3.10-1 Locations of Unreinforced Masonry Structures

\begin{tabular}{|l|}
\hline 227 Beach \\
\hline 611 Main \\
\hline 721 Main \\
\hline 105, 115 Second (Fire Station 1 ) \\
\hline Park Plaza Gazebo \\
\hline 180-186 Main \\
Source; City of Watsonville
\end{tabular}




\section{H Description of Land-Uses and Development Trends}

Although the City is anticipated to grow, development in the City is not likely to increase the vulnerability of the City to unreinforced masonry structures. Infill development may even reduce the vulnerability to URM structures as infill and redevelopment of existing structures will be built to a higher

building standard. Future building development will be of reinforced masonry and remodeling of existing structures will be required to reduce unreinforced masonry.

Hazards with Low Risk to the City: Airport Hazards, Civil Disturbance/ Terrorism, Dam Failure, Drought, Expansive Soils, Natural Gas Pipeline, Vehicle Accident The following hazard profiles are found to present a low risk to the City of Watsonville. While these hazards could occur within the city, there is a low likelihood of occurrence and any event would likely be minor in magnitude and severity. Each hazard is discussed for the potential to occur and affect the City, although specific risk and vulnerability is only generally discussed due to the low potential for significant impacts to the city.

\subsection{Airport Profile}

Due to ongoing litigation, further discussion of airport hazards will be completed once risk is analyzed by the General Plan Update to ensure compatibility between the LHMP and the General Plan. 
The Watsonville Municipal Airport has been a community and city anchor since it was built in 1942 and transferred to the City in 1948 after briefly being used by the Navy in WWII. The airport currently serves the City of Watsonville, the County of Santa Cruz, and portions of southern Santa Clara County and Northern Monterey County. The airport supports a number of economic activities in the vicinity of the City, attracts many visitors to the county and serves as a crucial lifeline in the event of an emergency. After the 1989 Loma Prieta Earthquake the Watsonville Airport was the only access point to the City when roadways were disrupted. In the event that City transportation routes are once again damaged or impassible, the airport would be crucial to emergency operations.

Due to the presence of the Watsonville Municipal Airport in the City, ground and flight hazard risks are present. Proper safety and airspace protection minimizes the number of people on and off the airport that are exposed to the risks associated with potential aircraft accidents and avoids flight hazards that interfere with aircraft navigation (Watsonville Municipal Airport 2001). The most recent Watsonville Municipal Airport Master Plan has identified distant obstacles, primarily hills to the north of the airport, and close-in obstacles, primarily trees and utility poles, that may impact flight safety. The airport is currently working to have these close-in obstacles removed.

\section{A Location}

Although most airport activity is centered around the airport in the northern area of the city, collision risks are present throughout the city because of the relative size of the city and the extent of the city that is below flight paths. The downtown area of the City is not directly under a flight path and thus is at a much lesser risk of experiencing a collision. 


\section{B Extent: Magnitude or Severity}

The magnitude and severity of potential aircraft collisions is based on the location in which the collision may occur. Airport flight paths are primarily over county land and avoid the more densely populated downtown. Potential magnitude or severity is more closely analyzed in respect to individual critical facilities in the vulnerability assessment.

Two variables determine the degree of risk posed by potential aircraft accidents: accident frequency and accident consequences (Watsonville Municipal Airport 2001).

\section{Previous Occurrences}

As with every airport there is a risk of airplane collision incidents. Since 1982 there have been 40 collision incidents and 11 fatalities in the city. None of the recorded accidents involved a serious injury or fatality to a civilian or a resident not involved with the aircraft. In comparison to regional airports of similar size and traffic amounts, the Watsonville Airport has had a significantly smaller number of recorded incidents.

Table 3.11-1 Previous Aircraft Collision Incidents (Since 1982)

\begin{tabular}{|r|l|l|}
\hline Date & Location & Injuries \\
\hline $7 / 20 / 2011$ & Collision occurred in a field location outside of the city. & $\begin{array}{r}0 \text { Injuries or } \\
\text { Fatalities }\end{array}$ \\
\hline $7 / 7 / 2011$ & Collision occurred 700ft southwest of the Runway 2 threshold. & $\begin{array}{l}4 \text { Fatalities } \\
\text { (onboard) }\end{array}$ \\
\hline $11 / 21 / 2009$ & $\begin{array}{l}\text { Collision occurred .25 miles from the end of Runway 20, east of the airport in } \\
\text { an apple orchard. }\end{array}$ & $\begin{array}{l}1 \text { Fatality } \\
\text { (onboard) }\end{array}$ \\
\hline $4 / 26 / 2007$ & Collision occurred in a wheat field near the airport. & $\begin{array}{l}1 \text { Minor Injury, } 1 \\
\text { Uninjured }\end{array}$ \\
\hline $9 / 15 / 2006$ & Collision occurred in a residential area approximately 2,000 ft from airport. & 1 Uninjured \\
\hline $6 / 12 / 2005$ & Collision occurred at the airport. & 3 Uninjured \\
\hline $8 / 30 / 2003$ & Aircraft collided with mountainous terrain 2.5 mi west from airport. & 3 Serious Injuries \\
\hline $12 / 15 / 2003$ & Collision occurred on airstrip. & 2 Minor Injuries \\
\hline $12 / 6 / 2003$ & Collision occurred in a field 4 miles south of the City. & 1 Uninjured \\
\hline
\end{tabular}




\begin{tabular}{|c|c|c|}
\hline $8 / 31 / 2000$ & Collision occurred approximately 2 to 3 miles from the airport. & 1 Fatality \\
\hline $8 / 18 / 2000$ & Collision occurred in an open dirt field 2.4 miles south of the airport. & 2 Fatalities \\
\hline $7 / 9 / 2000$ & Collision occurred in a cow pasture on hillside terrain. & 1 Minor Injury \\
\hline 9/4/1997 & Aircraft landed short of Runway 20 on airport property. & 2 Uninjured \\
\hline 5/23/1997 & Collision occurred in an open field 2.5 miles from airport. & 1 Minor Injury \\
\hline $11 / 7 / 1995$ & $\begin{array}{l}\text { Aircraft collided with the ground and a barn } .25 \text { miles from airport, at } 64 \\
\text { Manifre Road. }\end{array}$ & 1 Fatality \\
\hline 1/30/1994 & Collision occurred at the airport. & 2 Uninjured \\
\hline $1 / 18 / 1993$ & Unknown Location & $\begin{array}{l}1 \text { Minor Injury, } \\
1 \text { Uninjured }\end{array}$ \\
\hline 3/27/1992 & A helicopter collided into an agriculture field while spraying. & 1 Uninjured \\
\hline $12 / 21 / 1991$ & Collision occurred 1 mile from airport, at Compton Terrace at Vernon Court. & 4 Uninjured \\
\hline $6 / 24 / 1991$ & Collision occurred at airport. & 6 Uninjured \\
\hline 2/17/1991 & Collision occurred at airport. & 3 Uninjured \\
\hline $10 / 12 / 1990$ & Collision occurred at airport. & 3 Uninjured \\
\hline $9 / 18 / 1990$ & Collision occurred on a rough dirt strip close to the airstrip. & $\begin{array}{l}1 \text { Minor Injury, } 1 \\
\text { Uninjured }\end{array}$ \\
\hline 3/11/1990 & Collision occurred at airport. & 3 Uninjured \\
\hline 8/14/1989 & Unknown Location & 2 Uninjured \\
\hline 3/12/1989 & Collision occurred at airport. & $\begin{array}{l}1 \text { Serious Injury, } \\
1 \text { Uninjured }\end{array}$ \\
\hline 8/7/1988 & Collision occurred in a plowed field. & 2 Uninjured \\
\hline $6 / 27 / 1987$ & Aircraft collided with a field and trees after takeoff. & 1 Minor Injury \\
\hline 3/23/1986 & Unknown Location & 1 Minor \\
\hline 9/21/1985 & Unknown Location & 1 Uninjured \\
\hline 3/30/1985 & Unknown Location & 1 Uninjured \\
\hline $8 / 29 / 1984$ & Unknown Location & 1 Uninjured \\
\hline $8 / 18 / 1984$ & Aircraft landed in a field during agriculture spraying. & 1 Uninjured \\
\hline $2 / 22 / 1984$ & Collision occurred at airport. & 1 Minor Injury \\
\hline $1 / 4 / 1984$ & Aircraft landed in a field during agriculture spraying. & 1 Uninjured \\
\hline 9/19/1983 & Collision occurred at airport. & 1 Uninjured \\
\hline $7 / 22 / 1983$ & Aircraft collided with Mount Madonna hillside. & 2 Fatality \\
\hline $1 / 22 / 1983$ & Collision occurred at airport. & 2 Uninjured \\
\hline $1 / 23 / 1982$ & Aircraft landed in a field during agriculture spraying. & 1 Uninjured \\
\hline
\end{tabular}

Source: National Transportation Safety Board Aviation Query 


\section{Probability of Future Events}

The Watsonville Municipal Airport has a good safety record and aircraft collisions are not easily predicted. The airport will continue to implement safety measures to decrease the probability of aircraft collisions.

\section{E Vulnerability Assessment}

The vulnerability of Watsonville to aircraft activity is based on the density of the city and the amount and type of aircraft activity at the airport. Due to the presence of the airport in the City, there is an existing vulnerability to the threat of aircraft collisions in the City. The location and extent of an aircraft collision is difficult to predict, however landing and takeoff aircraft operations are the more risky and thus the potential for collision is greater during these operations which occur closer to the airport. Flight paths can also be used to determine potential locations of vulnerability, although most of the take off and landing flight paths for the airport are located outside of the City limits. Examination of past aircraft incidents have shown that for the incidents where locations have been identified, many collisions have occurred within a 3 mile radius of the airport.

It is important to note that the Watsonville Municipal Airport has a very good safety record and that the current vulnerability of the City to aircraft collisions is low based on records of past events. Previous aircraft collisions have had a low injury and fatality rate and in the records examined over the past 30 years, there have been no injuries or fatalities to people on the ground. 


\section{F Vulnerable Types and Numbers of Existing Buildings, Facilities, and Infrastructure}

Based on the examination of past aircraft collisions, structures within a 3 mile radius of the airport are more vulnerable to aircraft collision that those outside of this radius. No specific structure within this radius is more or less vulnerable to aircraft collisions. Underground infrastructure is not vulnerable to aircraft collisions.

\section{G Description of Land-Uses and Development Trends}

The vulnerability of the present and future population to airport hazards will be dependent upon density and the proximity of these populations to the airport as well as the type and amount of airport activity. Increased development in the City would reduce the number of places in and around the City that could be used by pilots in emergency situations. Increased density would also increase the number of people vulnerable to an aircraft collision.

Although intense expansion of the airport is not anticipated, such an expansion would likely increase the amounts and types of aircraft present in the city and would increase the vulnerability of the City to aircraft collisions. 


\subsection{Civil Disturbance/ Terrorism Profile}

During civil disobedience events, public disobedience may result in harm to or disruption of city facilities or infrastructure. Similar disruption may occur in the event of a terrorism event in which particular public spaces or infrastructure is disrupted or destroyed. Both civil disobedience and terrorism events could result in threats to public safety and disruption of public services.

\section{A Location}

Civil disobedience events are more likely to occur in public gathering areas or in the event of a strike, in the vicinity of a specific office or workplace. Terrorist attacks are most likely to be in public gathering areas or significant city facilities.

\section{B Extent: Magnitude or Severity}

Due to the size and distribution of the City, it is unlikely that a large or particularly severe civil disturbance or terrorism event would occur. If an event were to occur, it would most likely be isolated to a particular area and areas outside of the effected area would still be able to operate. City services are relatively dispersed throughout the city, and unless particular singular facilities were targeted, unaffected city services would most likely be able to serve affected ones. 


\section{Previous Occurrences}

Throughout the history of the City, Watsonville has experienced one major civil disturbance event which was the cannery strike from 1985-1987. Events of the strike resulted in some violence and vandalism. There have not been any terrorist attacks on the City.

\section{Probability of Future Events}

Due to the size and regional significance of the City, there is a very low probability that a terrorism event or another civil disobedience event would occur in the City.

\section{E Climate Change Considerations}

Climate change is not anticipated to impact the potential for civil disturbance or terrorism in the City.

\section{F Vulnerability Assessment}

Based on Watsonville's history of infrequent civil disturbance, there is a low vulnerability to the City of civil disturbance and terrorism.

\section{G Types and Numbers of Existing Buildings, Facilities, and Infrastructure}

In the unlikely event of civil disturbance or terrorism, likely locations for such events would be in the downtown either in the central plaza or in front of civic buildings. The Civic Plaza could be damaged, as 
could above ground utilities and infrastructure. Underground infrastructure is not vulnerable to civil disturbance or terrorist attack.

\section{H Description of Land-Uses and Development Trends}

As with many communities, the City of Watsonville is striving to address increased housing costs which has resulted in the need to provide higher density housing and affordable housing. The increase of housing is indented to address present needs as well as future growth projections. Anticipated growth will occur in areas not currently built out and additional development will be infill, reuse, and increased development on existing residential properties.

Increased growth in any area of the City may result in a slightly greater risk of civil disturbance or terrorism but it is not anticipated to increase the vulnerability of the city.

\subsection{Dam Failure Profile}

Dam failure can occur as a result of seismic activity, structural instability, or intense rain in excess of design capacity. Dams must have spillway systems to safely convey normal stream and flood flows over, around, or through the dam and a drain or other water-withdrawal facility to control the reservoir level for maintenance or emergency purposes. In the event of dam failure, large volumes of water may continue downstream into infrastructure or areas that are incapable of controlling the flow or amount of water. The rapid release and large amount of water that may accompany a dam failure may also carry debris downstream that could further damage infrastructure, structures or harm the population (County of Santa Cruz 2010). 


\section{A Location}

There is one dam within the County of Santa Cruz that is regulated by the State Division of Safety of Dams. The Soda Lake Dam is located along Highway 129 but is the responsibility of Granite Rock Company. There are three additional State-regulated dams located outside of the county which are upstream of Watsonville. These dams are Elmer J. Chesbro and Uvas Dams in Santa Clara County which are under the jurisdiction of the Santa Clara Valley Water District and the San Justo Dam in San Benito County which is in the San Benito County Water District and within the jurisdiction of the Federal Bureau of Reclamation.

There are an unknown number of other dams outside of the City of Watsonville that are associated with agriculture, small water systems and private ponds. These facilities are likely non-jurisdictional.

Table 3.13-1: Dams in the Proximity of the City of Watsonville

\begin{tabular}{|l|l|l|l|l|l|l|}
\hline Name & Owner & County & Stream & Year Built & $\begin{array}{l}\text { Capacity } \\
\text { (Ac-Ft) }\end{array}$ & $\begin{array}{l}\text { Res. Area } \\
\text { (Acres) }\end{array}$ \\
\hline Soda Lake & $\begin{array}{l}\text { Granite Rock } \\
\text { Co. }\end{array}$ & Santa Cruz & $\begin{array}{l}\text { Tr. Pajaro } \\
\text { River }\end{array}$ & 1978 & 1,983 & 72 \\
\hline $\begin{array}{l}\text { Elmer J. } \\
\text { Chesbro }\end{array}$ & $\begin{array}{l}\text { Santa Clara } \\
\text { Water District }\end{array}$ & Santa Clara & $\begin{array}{l}\text { Llagas Creek } \\
\text { (PR) }\end{array}$ & 1955 & 7,945 & 283 \\
\hline Uvas & $\begin{array}{l}\text { Santa Clara } \\
\text { Water District }\end{array}$ & Santa Clara & $\begin{array}{l}\text { Uvas Creek } \\
\text { (PR) }\end{array}$ & 1957 & 9,835 & 288 \\
\hline San Justo & $\begin{array}{l}\text { Bureau of } \\
\text { Reclamation }\end{array}$ & San Benito & Off Stream & 1987 & 10,300 & 202 \\
\hline
\end{tabular}

Source: County of Santa Cruz 2010 


\section{B Extent: Magnitude or Severity}

Soda Lake is a storage facility from the Wilson Quarry in San Benito County, and failure of the Soda Lake levees could release fine-grained material and encroach upon Highway 129, approximately 8 miles outside of the City (County of Santa Cruz 2010). The reservoir of Soda Lake Dam is small and highly silted. It is unlikely that failure at Soda Lake would have a large or severe impact on the City of Watsonville.

San Justo Dam is located at San Justo Reservoir outside of the City of Hollister and approximately 22 miles from the City of Watsonville. The off-stream reservoir is considered to be far enough away from the City of Watsonville that any failure of the dam would not cause a significant impact on the City.

The City of Watsonville is outside of the inundation areas for Chesbro and Uvas Dams. In the event of a dam failure at either Chesbro or Uvas Dams, there may be elevated surface levels in the Pajaro River, but there is very little probability that dam failure would affect structures or residences within the City of Watsonville.

Given their location and size, failure of a non-jurisdictional dam could affect a limited amount of people or property in downstream areas. For this unknown number of dams the extent of this non-jurisdictional dam failure hazard is currently unknown (County of Santa Cruz 2010). 


\section{Previous Occurrences}

After the Loma Prieta earthquake, an extensive set of cracks was observed at the crest of the Soda Lake west embankment and adjacent areas. The west levee was excavated to bedrock and reconstructed in 1997 with the approval of the California Division of Safety of Dams. Additional stability issues involving the north levee tie-in to the hillside have been addressed by the Division of Safety of Dams in a letter or Granitrock Company dated September 20, 2000(County of Santa Cruz 2010). There are no other instances of damage or failure of any of the identified dams.

\section{Probability of Future Events}

Currently available information gives no indication that any of the dams discussed above would fail or otherwise sustain damage during a natural disaster.

\section{E Climate Change Considerations}

Climate change is not anticipated to impact the risk or probability of dam failure.

\section{F Vulnerability Assessment}

The City of Watsonville is located outside of the potential dam inundation areas of nearby dam structures. Thus, critical city facilities and city residences are not vulnerable to dam inundation. A small risk does remain if Soda Lake dam fails; in this instance Highway 129 may be affected which would impact an evacuation route system for the City. 


\section{G Vulnerable Types and Numbers of Existing Buildings, Facilities, and Infrastructure}

The City is not vulnerable to dam failure and thus there are no City structures that are vulnerable to dam failure. Highway 129 is not a City facility, although it is identified as an evacuation route for the city. It may be impacted if Soda Lake dam were to fail.

\section{H Description of Land-Uses and Development Trend}

Although the city is anticipated to grow in future years, anticipated growth is located to the north and west of the existing City limits and is not anticipated to encroach upon any dam inundation areas which are located much further to the north or east of the city.

\subsection{Drought Profile}

Drought is a period of dry weather that continues for a long enough time to cause problems such as water supply shortages or crop damage. While droughts do occur with regularity, they are unpredictable and will have varying types of severity. Historic resources may guide water resources planning in anticipating the frequency and severity of droughts.

The Watsonville City Water District serves the City of Watsonville and areas of unincorporated Santa Cruz County including parts of Corralitos, Freedom, and Pajaro Dunes. The service area consists of 9 hydraulic pressure zones, 14 wells, 8 reservoirs and water storage facilities, 9 booster stations, over 150 miles of pipelines and a slow sand filter water treatment plant. The City's regional water system currently 
delivers to over 65,000 customers (City of Watsonville 2010a). Most, 84.4\%, of the 25,597 acre-feet of water per year that is produced by the district is from groundwater sources. Surface water comprises 9.4\% of the district's water supply, and $6.2 \%$ is recycled water used for agriculture. The City's wells and surface water supplies are capable of providing both current and projected water demands particularly as surface water infrastructure could be improved to process available surface water at a greater capacity, inland wells could be operated at a higher capacity, and a greater amount of wastewater could be recycled (City of Watsonville 2010a).

Overdraft is a concern in the Pajaro Valley Basin (which includes the Watsonville City Water District). The Watsonville City Water District is currently cooperating with the Pajaro Valley Water Management Agency, which oversees the Pajaro Valley Basin, to reduce the amount of pumping from wells that induce seawater intrusion. Continued water management and cooperation between agencies will reduce ecosystem pressures of overdraft and saltwater intrusion.

There are multiple water sources in the City water system and in the event of a disaster, if one source of water or a water zone is damaged, water can be supplied from another area of the City. Additionally, each area within the service system is served by multiple wells, thus limiting dependence on a single supply source. Nearly all source water sites are equipped with emergency back-up generators and fuel tanks that will keep the system operational during emergencies for at least 1-3 days depending on the site, and can be extended with refueling(City of Watsonville 2010a).

In the event of a drought or long-term infrastructure failure, such as occurred from 1989 after the Loma Prieta earthquake to 1996, the City would depend more heavily on groundwater. City wells are not currently run at full capacity, and can supply additional water if necessary. The maximum safe yield is the quantity of water that can be produced from the City groundwater system, based on the historical production capacity of the aquifer and the pumping capacity of the well equipment. 
Surface water sources are more susceptible to drought impacts and thus because the City utilizes more groundwater than surface water, Watsonville is less susceptible to risk in the event of a drought.

Table 3.14-1City of Watsonville Water Sources

\begin{tabular}{|l|l|l|}
\hline Type & Amount & Percentage of Total Amount Used \\
\hline Groundwater & 21,600 acre-feet per year & $84.4 \%$ \\
\hline Surface water & 2,400 & $9.4 \%$ \\
\hline Recycled Water & 1,597 & $6.2 \%$ \\
\hline Total & 25,597 & $100 \%$ \\
\hline
\end{tabular}

\section{A Location}

A drought, or multiple dry years would affect the region and create widespread water shortages. The City's water supply would not be severely limited due to the prevalence of groundwater sources. The agriculture area outside of the City may be impacted which may have secondary economic consequences for Watsonville.

\section{B Extent: Magnitude or Severity}

The Watsonville City Water District's Resolution Declaring a Water Supply Emergency and Establishing Water Use Reductions determined that even in the event of a drought, a City water shortage is highly unlikely over the next 20 years due to the stable supply of groundwater and the City's groundwater pumping and distribution capacity(City of Watsonville 2010a).The City can provide reliable water supplies not only under normal conditions but also under both the single driest year and the multiple dry year events. 


\section{Previous Occurrences}

Santa Cruz County has experienced three drought periods in recent history: 1976-1977, 1987-1992, 20072009. The two longest droughts in California History were from 1923-1935 and 1987-1992. Year 1976 was the lowest recorded year of rainfall since 1903 (City of Watsonville 2010a). The 1989-1992 drought is the reference for the multiple dry year period and was the period generally considered to be the lowest average runoff for a consecutive multiple year period (three years or more) for a watershed since 1903(City of Watsonville 2010a).

\section{Probability of Future Events}

Droughts are anticipated to continue, although due to the minimal impact droughts have on the City of Watsonville water supply, future droughts are not anticipated to have significant impacts on the City.

\section{E Climate Change Considerations}

Climate change is anticipated to impact the frequency and severity of future droughts. Changes in climate may reduce the amount of seasonal rainfall and may prolong the periods between wet years, both which would induce drought conditions. While Watsonville is not significantly susceptible to drought, extreme dry periods would have impacts on the City. Secondary economic impacts are also a concern for the City if the agriculture activity in surrounding areas is impacted by drought caused by climate change. 


\section{F Vulnerability Assessment}

The City of Watsonville has a low vulnerability to drought due to the diversity of water sources used by the City. The City relies on both surface water and groundwater to fulfill water needs and thus is not vulnerable to water shortages during a drought. If water shortages as a result of drought do occur, rationing would go into effect. Conservation programs and curtailment programs are both components that will further decrease the vulnerability of Watsonville to drought.

\section{G Vulnerable Types and Numbers of Existing Buildings, Facilities, and Infrastructure}

Structures and facilities are not vulnerable to drought. Physical losses would likely be limited to public and private landscaping. However, the impacts to landscaping, which occur as the result of severe drought conditions, also increase the risk of fire and subsequent damage to structure as a result.

\section{H Description of Land-Uses and Development Trends}

The City of Watsonville Public Works and Utilities Department supplies and delivers water to an area much greater than the city limits. This water service area has generally remained constant over time. Future growth of the City will increase the water demands on the city but will likely not substantially increase the size of the service district. This growth has been accounted for in the Urban Water Management Plan and will not significantly increase the vulnerability of the City to drought. 


\subsection{Expansive Soils Profile}

Expansive soils are generally clays or sedimentary rocks derived from clays, which experience volume changes as a result of moisture variation. The damage that expansive soils create can be severe. Many of the expansive soils do not create large areas of destruction; however, they can disrupt supply lines (i.e. roads, power lines, railways, and bridges) and damage structures. The effects on structures can be dramatic if expansive soils supporting structures are allowed to become too wet or too dry. Lightly loaded one- or two-story buildings, warehouses, residences, and pavements are especially vulnerable to damage because these structures are less able to suppress the differential heave of the swelling foundation soil than heavy, multistory structures. Expansive soils do not change size quickly; observing damage in realtime can sometimes be difficult. Although the damage might not occur in a matter of minutes, it still has the potential to severely damage structures and roads over a matter of time if not sufficiently mitigated. However, expansive soil doesn't cause problems unless poorly designed structures are built on it. A house built on expansive soil will probably move if the foundation was not designed to take this soil type into account. Movement occurs because the soils expand so forcefully, the foundation actually moves. Different parts of the house can move at different rates and distances, thus cracking the foundation. Significant cracks often appear at the corners of windows and doors, in walls, garage slabs, walkways, and driveways. Doors and windows may become jammed. The integrity, design, value and use of a home could be affected. During extreme drought conditions, even homes that are not normally affected by expansive soil problems may experience slight cracking (County of Santa Cruz 2010). 
Figure 3.15-1 Expansive Soils

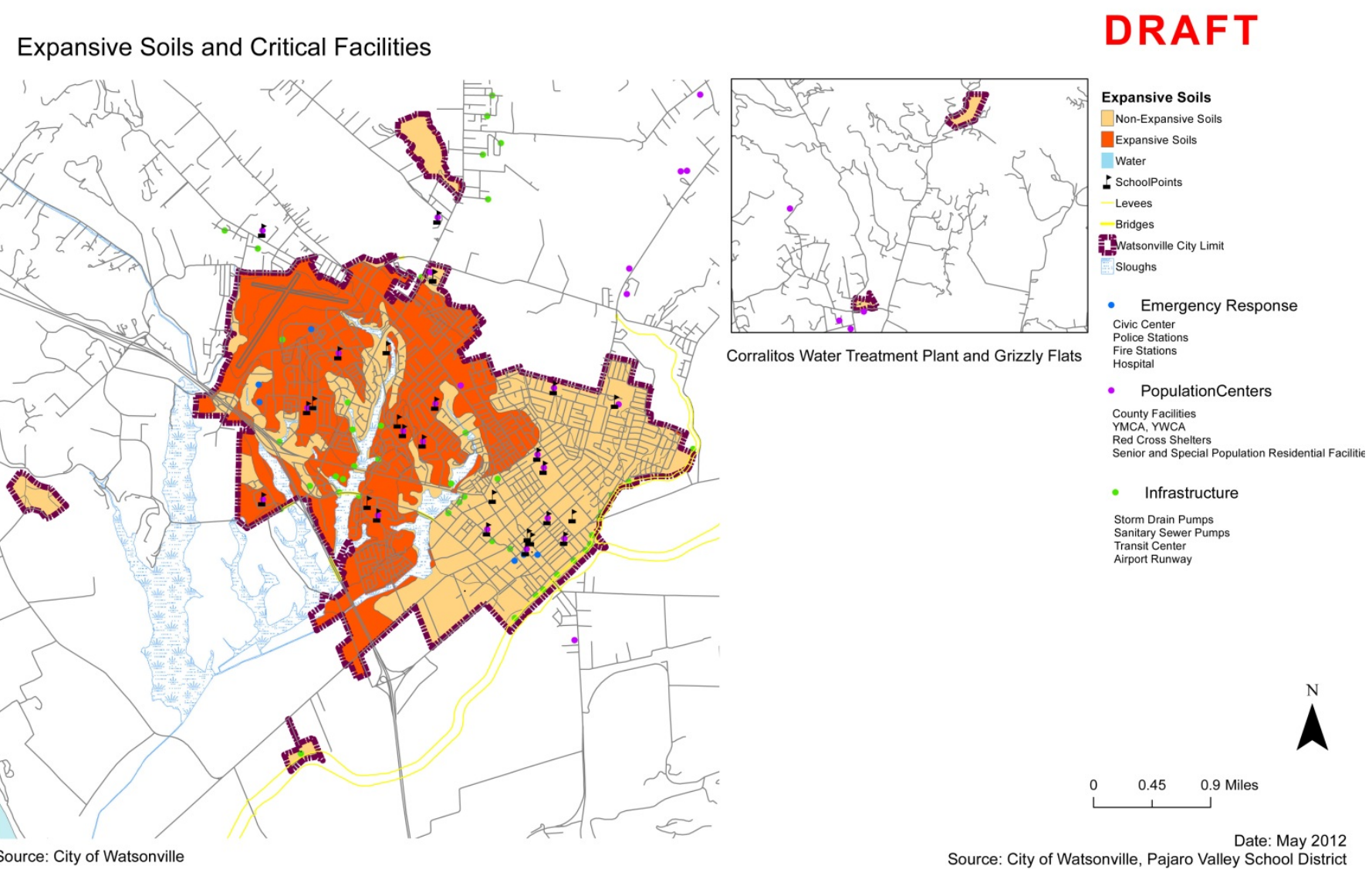

\section{A Location}

The expansive primary soil types mapped by NRCS present in the City are Watsonville Loam, Clear Lake Clay, Diablo Clay, Pinto Loam, CropleySilty Clay, Danville Loam and minor components of Los Osos Loam. The general locations of expansive soils in the City are in the western region of the city, primarily adjacent to slough areas (County of Santa Cruz 2010). 


\section{B Extent: Magnitude or Severity}

Each year in the United States, expansive soils cause billions of dollars in damage to buildings, roads, pipelines, and other structures. This is more damage than that caused by floods, hurricanes, tornadoes, and earthquakes combined (County of Santa Cruz 2010). It is estimated that the City of Watsonville has many homes built on expansive soils. Typically, the structures that experience problems with expansive soils are older homes, but newer homes (built within the last 15 years) may also experience problems due to expansive soils. The types of problems associated with expansive soils are generally not catastrophic, but the effects result in cracked foundations, cracked walls, cracked concrete slabs, cracks around windows and doors, as well as jammed windows and doors. Cracks to foundations may lead to additional problems if other catastrophic events were to occur, such as earthquakes(County of Santa Cruz 2010).

\section{Previous Occurrences}

The number of occurrences is difficult to measure, since property owners may consider the effects of expansive soils to be minor and therefore choose not to do anything about it(County of Santa Cruz 2010).

\section{Probability of Future Events}

Structures in the City of Watsonville will have the potential to experience problems with expansive soils on a yearly basis as moisture conditions in soils fluctuate. Recent revisions to the Building Codes 2007 California Building Code (CBC) Section 1802 and the 2006 International Building Code), have provided local jurisdictions with new tools to request soils reports for building permits in areas where expansive soils are suspected and have detailed procedures to determine when soils are considered expansive. In 
addition, Section 1805.8 of the 2007 CBC provides requirements for design for expansive soils. Therefore, over time it is anticipated that there will be fewer problems with structures due to expansive soils(County of Santa Cruz 2010).

\section{E Climate Change Considerations}

Whether or not a soil is expansive is not related to climate. Climate change is not anticipated to impact the risk of expansive soils.

\section{F Vulnerability Assessment}

Typically, the structures that experience problems with expansive soils are older homes, but newer homes (built within the last 15 years) may also experience problems due to expansive soils. The types of problems associated with expansive soils are generally not catastrophic, but the effects result in cracked foundations and walls. Cracks to foundations may lead to additional problems if other catastrophic events were to occur.

Many of the soils within the city are expansive soils. Each structure built on expansive soils is at risk of damage, but underground infrastructure may be particularly vulnerable as incremental damage is more difficult to identify. Vulnerable facilities include storm drains, sanitary sewer drains, water mains, and a PG\&E natural gas transmission pipeline. 


\section{G Description of Land-Uses and Development Trends}

As with most communities, increased housing costs have resulted in the need to provide higher density housing and affordable housing. Anticipated growth will occur both inside the City and outside of the existing City limits. Additional development will be infill, reuse, and development of existing residential properties. Expansive soils are common throughout the City and the surrounding areas and thus it is likely that future development will occur on expansive soils. However the vulnerability of damage to these structures is likely to be mitigated by updated and superior building requirements.

\subsection{Natural Gas Pipeline Profile}

The City is dependent upon natural gas distribution and transmission lines to supply natural gas to the city. If a pipeline were to fail, including pipe breaks and explosions, the failure could result in the loss of life, injury, property damage, and environmental impacts. Causes of contributors to pipeline failures include construction errors, material defects, internal and external corrosion, operational errors, control system malfunctions, outside force damage, subsidence, and seismicity. Growth in population, urbanization, and land development near transmission pipelines, together with addition of new facilities to meet new demands, may increase the likelihood of pipeline damage due to human activity and the exposure of people and property to pipeline failures (California Emergency Management Agency 2010).

Specific information on pipeline vulnerability is maintained by the owner/operator, PG\&E. PG\&E monitors system status in real time on a 24-hour basis and regularly conducts leak inspections, surveys, and patrols of all its natural gas transmission pipelines to identify issues to be addressed immediately. PG\&E also uses the data it collects to help plan and set priorities for future work. One of the tools PG\&E uses is a risk management program that inventories and evaluates each of the 20,000 segments within 
PG\&E's natural gas transmission pipeline system. A pipeline segment may be identified for further study and long-range planning based on its risk for one of several factors:

- Potential for third-party damage

- Potential for corrosion

- Potential for ground movement

- Physical design and characteristics

PG\&E also considers proximity to high-density populations, potential reliability impacts, and environmentally sensitive areas. Based on these factors, PG\&E determines which segments warrant further evaluation, monitoring, or other future action. PG\&E also creates a list of the "Top 100" segments to help inform future work plans. As conditions change from year to year, PG\&E reevaluates the segments included on the list (California Emergency Management Agency 2010). None of the segments on the most recent “Top 100” list are located in, or in the proximity of Watsonville. 
Figure 3.16-1 Approximate PG\&E Natural Gas Transmission Pipeline Location

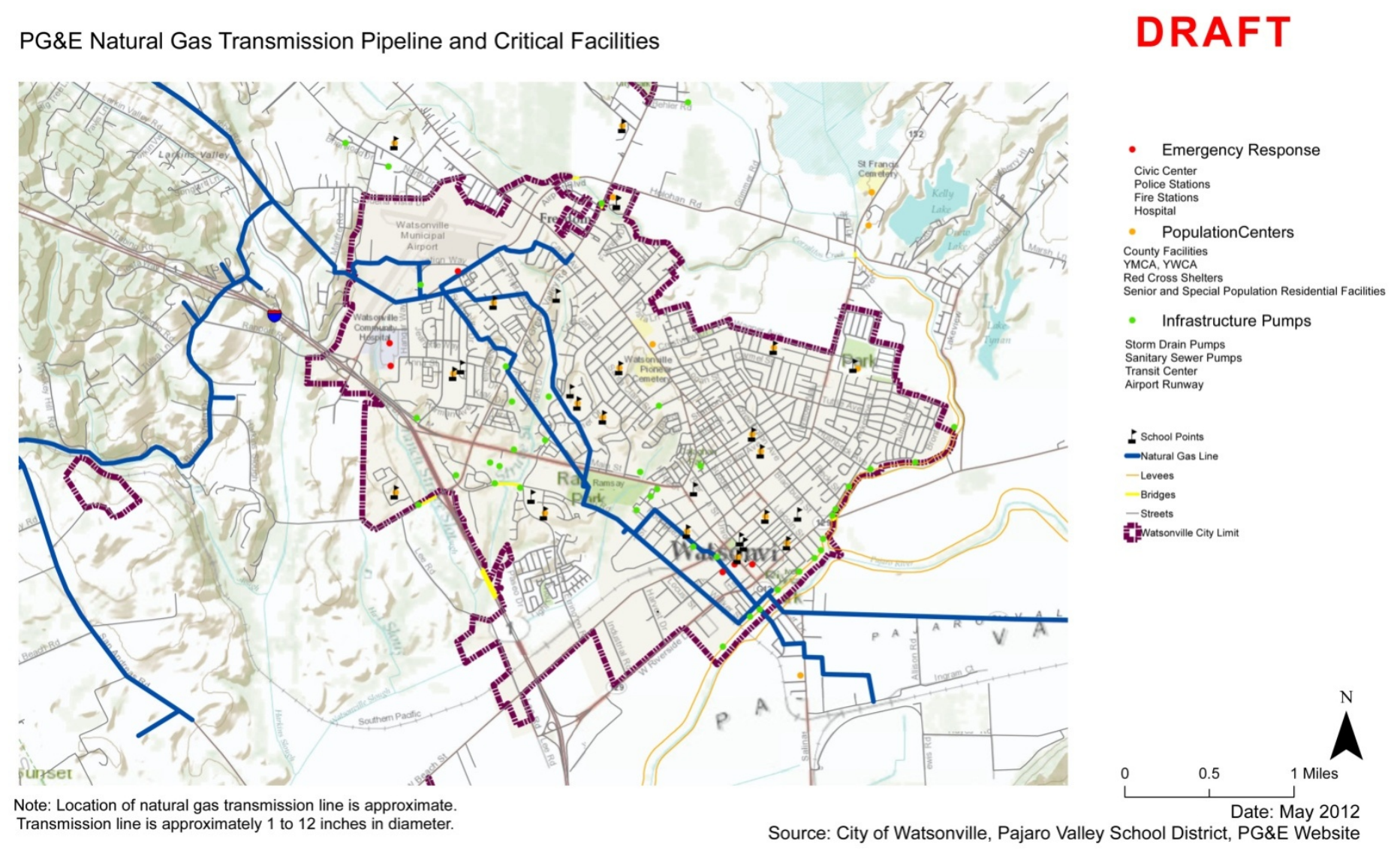

\section{A Location}

The location of a potential natural gasline hazard is dependent upon the location of transmission and distribution pipelines. A PG\&E natural gas transmission pipeline is located through the City.

\section{B Extent: Magnitude or Severity}

The magnitude and severity of potential natural gasline hazards is dependent upon the size and extent of damage to the pipeline. The potential hazard of a natural gas pipeline increases with the size of the 
distribution or transmission line, the proximity of a population to the pipeline, and the age and condition of the pipeline.

\section{Previous Occurrences}

Natural gasline damage during the 1989 Loma Prieta earthquake caused numerous fires and damage throughout the City when structures shifted and lines were severed. Natural gasline hazard remains a concern in the event of an earthquake. There are no known instances of a natural gasline blowout outside of earthquake events within the City of Watsonville.

\section{Probability of Future Events}

No known current assessment of vulnerability or potential losses from gas pipeline failure is currently available. However, it can be logically assumed that any facility in close proximity to a natural gas transmission pipeline is at risk. This risk is heightened if the facility is also located in an area of high seismicity, where multiple gas line failures and resulting fires can be expected (California Emergency Management Agency 2010).

\section{E Vulnerability Assessment}

Several natural gas transmission pipelines traverse the city which creates a risk of infrastructure failure and fire. Vulnerability of the city is based on the size of the pipelines, the age and condition of the pipelines, and the location of the pipelines. An approximate location for these pipelines is known, although the age and condition are unknown and significantly influences the vulnerability of the City to 
natural gas pipeline failure. For a more precise analysis of the City’s vulnerability, additional information is required from PG\&E, the owner/operators of the pipelines.

\section{F Types and Numbers of Existing Buildings, Facilities, and Infrastructure}

The precise risk to the city from the natural gas transmission pipeline is unclear and thus it is difficult to determine vulnerability except by location. Table 3.16-1 shows the proximity of critical facilities to the pipeline.

Table 3.16-1 Number of Critical Facilities Within 1000 Ft of a Natural Gas Transmission Pipeline

\begin{tabular}{|l|l|}
\hline Critical Facility Type & Number of Facilities \\
\hline Bridges & 2 \\
\hline City Hall & 1 \\
\hline Civic Plaza & 1 \\
\hline County Facilities & 0 \\
\hline Daycare Facilities & 62 \\
\hline Fire Stations & 2 \\
\hline Historic Sites or Historic Sites of Interest & 34 \\
\hline Hospital & 0 \\
\hline Police Headquarters & 1 \\
\hline Population Centers & 5 \\
\hline Red Cross Primary Shelters & 5 \\
\hline Schools & 9 \\
\hline Storm Drain Pumps & 0 \\
\hline Sanitary Sewer Pumps & 0 \\
\hline Transit Center & 0 \\
\hline
\end{tabular}

\section{G Description of Land-Uses and Development Trends}

The vulnerability of the present and future population will be dependent upon the proximity of these populations to natural gas transmission pipelines and the continuing safe operation and maintenance of 
these pipelines. With increased development and density, there is an increased vulnerability of these populations to gas pipeline failure.

\subsection{Vehicle Collisions (Train, Truck, Car) Profile}

A collision by a train, truck or car has the potential to disrupt City operation by blocking roadways or rail lines. If a collision were to occur during a hazardous event the effects on the city may impact emergency response and be significant. Hazardous materials are moved through the city by truck and by train and a collision of either with hazardous materials on board may impact public safety.

\section{A Location}

Primary locations for train and truck collisions are on railways and truck routes. Car collisions may occur along any roadway, but are of particular concern on the larger roadways, which also serve as major evacuation routes from the City.

\section{B Extent: Magnitude or Severity}

Industrial and agricultural transportation are active in the City, although the amount of such traffic within the City is relatively low which reduces the potential for a multiple-vehicle collision and reduces the potential magnitude of a vehicle collision. Travel speeds for all types of vehicles are slow throughout the city which reduces the potential severity of vehicle collisions. 


\section{Probability of Future Events}

In any situation including vehicles, there is a potential for a collision to occur. Even with the varied types of materials and vehicles traveling through the City, the speed and magnitude of travel results in a low potential for a significant hazardous event to occur and also reduces the potential severity of future events.

\section{Vulnerability Assessment}

The City of Watsonville is not vulnerable to vehicle collisions due to the low incidence rate of significant collisions.

Hazards Which Present a Low to No Risk to the City: Tornados and Tsunamis

The following hazards present either a very low risk to the city, or may only present a low risk to a city in the event of climate change.

\subsection{Tornado Profile}

A tornado is a violent windstorm characterized by a twisting, funnel-shaped cloud. It is spawned by a thunderstorm and produced when cool air overrides a layer of warm air, forcing the warm air to rise rapidly. The damage from a tornado is a result of the high wind velocity and wind-blown debris (County of Santa Barbara 2004). 


\section{A Location}

The region and city do not normally experience the climate conditions for tornados, although 4 minor tornados have occurred in or near the city since 1950. These tornado events were minor and caused minimal damage.

\section{B Extent: Magnitude or Severity}

There have been very few tornado events in Santa Cruz County. The tornado events that have occurred over the past 50 years have been minor. Based on previous occurrences, future tornados would likely be minor and would not cause severe damage.

\section{Previous Occurrences}

Tornados are rare in California although 4 minor tornados have occurred in Santa Cruz County since 1950. All of the tornados were minor, and there have been no injuries or fatalities. The most recent occurrence, on December 20, 2001, resulted in downed trees, damaged roofs, some collapsed outbuildings and a power outage. There were no injuries.

Table 3.18 Previous Occurrences of Tornados in Santa Cruz County

\begin{tabular}{|l|l|l|l|}
\hline Date & Location & Magnitude & Damage \\
\hline April 1, 1965 & $\begin{array}{l}\text { Amesti Road, } \\
\text { Corralitos }\end{array}$ & F1 & $\begin{array}{l}\text { Less than a thousand } \\
\text { dollars }\end{array}$ \\
\hline February 3, 1986 & $\begin{array}{l}\text { Highland Drive, } \\
\text { Aptos }\end{array}$ & F0 & $\$ 3,000$ \\
\hline December 5, 1998 & $\begin{array}{l}\text { Water Street, Santa } \\
\text { Cruz }\end{array}$ & F0 & $\$ 50,000$ \\
\hline December 20, 2001 & $\begin{array}{l}\text { Watsonville Airport, } \\
\text { Watsonville }\end{array}$ & F1 & $\$ 250,000$ \\
\hline
\end{tabular}

Source: NOAA 


\section{Probability of Future Events}

Based on past events, it is likely that small tornados will continue to occur infrequently.

\section{E Climate Change Considerations}

Tornados are impacted by climate and climate change could impact the frequency and intensity of tornados in and around Watsonville. Due to the very low frequency and intensity of tornados that have occurred in the Watsonville region, it is doubtful that climate change will severely impact tornados in Watsonville without a substantial change in climate.

\section{F Vulnerability Assessment}

Based on Watsonville's history of infrequent tornados, there is a very low vulnerability to the City of tornados. The City is not considered vulnerable to tornados.

\subsection{Tsunami Profile}

A tsunami is a series of waves generated by an impulsive disturbance in a large body of water such as an ocean or a large lake. Tsunamis are produced when movement occurs on faults in the ocean floor, usually during very large earthquakes but may also occur due to landslides or similar movement. Overlaying water is displaced which creates a wave that travels outward from the source. An earthquake anywhere in the Pacific Ocean can cause tsunamis around the entire Pacific Region, including offshore of the City of Watsonville. As the Pacific Rim is seismically active, tsunamis are not uncommon. Historically those 
that have reached the Central Coast have been small and thus there has been minimal damage and loss of life offshore of Santa Cruz County.

While the City is not within a tsunami inundation area, a number of roadways within the city serve as evacuation routes for those areas outside of the city that are in an inundation area. A tsunami has the potential to indirectly impact the City by requiring evacuation operations on designated roadways and may have additional impacts from climate change.

\section{A Location}

Several active and potentially active earthquake faults are located within or near the City of Watsonville. An earthquake occurring on or near any of the nearby faults, or submarine landsliding in Monterey Bay could result in local source tsunamis. Additionally, distinct source tsunamis from elsewhere along the Pacific Rim are also capable of causing tsunamis that would affect the offshore area near the City. However, the City of Watsonville, including the wastewater treatment plant on the Pajaro River, is located outside of the tsunami inundation area that is identified for the coast. Tsunamis generated by either distinct or local source tsunamis would not impact the city.

\section{B Extent: Magnitude or Severity}

Tsunami inundation may travel along the Pajaro River but it is anticipated that even in the event of a localized tsunami such as one that occurs due to a submarine landslide, inundation will not reach the wastewater treatment plan or any other area of the city. 


\section{Previous Occurrences}

There have been no known instances of tsunamis impacting the City of Watsonville, likely due to it’s location outside of the tsunami inundation zone.

\section{Probability of Future Events}

It is unlikely that a tsunami will impact the City of Watsonville due to its location outside of the tsunami inundation zone. If a tsunami were to occur, there may be secondary impacts to the City, such as heavier traffic on City roadways which are identified as evacuation routes.

\section{E Climate Change Considerations}

Tsunamis are not associated with climate and thus it is not anticipated that climate change will impact the frequency or severity of tsunamis. However, climate change may result in sea level rise which could result in the tsunami inundation area to include the City. While there is no current risk to the City from tsunamis, impacts of climate change and sea level rise could result in a future risk to the City.

\section{F Vulnerability Assessment}

The City of Watsonville is not vulnerable to tsunamis. The City is outside of the tsunami inundation zone, even for a locally-sourced tsunami.

\section{G Types and Numbers of Existing Buildings, Facilities, and Infrastructure}


None of the structures in the City of Watsonville are vulnerable to tsunamis, due to the City's location outside of the tsunami inundation zone.

\section{H Description of Land-Uses and Development Trends}

Although the city is anticipated to grow in future years, anticipated growth is located to the north and west of the existing City limits and is not anticipated to enter the identified tsunami inundation area which is located to the south of the city.

\subsection{Hazards That Do Not Present a Risk to the City: Avalanche, Coastal Erosion, Coastal Storm, Extreme Heat, Winter Storms and Hailstorms, Volcano}

The following hazard profiles are found to not present any risk to the City of Watsonville. In some cases hazards are more specifically discussed, based on the potential risk to surrounding areas but not to the City.

\section{Avalanche}

An avalanche is defined as a mass of loosened snow, ice, or earth suddenly and swiftly sliding down a mountain. In general practice this is assumed to be a snow avalanche unless another term such as ice, rock, mud, etc, is used. The Sierra Nevada Mountains which are over 200 hundred miles from Watsonville are the nearest area with a risk of avalanche. This is not considered a significant hazard risk to Watsonville. 


\section{Coastal Erosion}

Coastal erosion is the wearing away of coastal land. It is commonly used to describe the horizonatal retreat of the shoreline along the ocean. Erosion is considered a function of larger processes of shoreline change. Erosion occurs when more sediment is lost along a particular shoreline than is redeposited by the water body. The City of Watsonville is not subject to coastal erosion due to its inland location.

\section{Extreme Heat}

Exposure to excessive heat can cause illness, injury and death. Approximately 400 people die each year in the United States from exposure to heat due to weather conditions, and many more people die from health conditions that are exacerbated by exposure to excess heat. Most heat-related deaths occur during the summer months. The elderly, very young, and people with chronic health problems are most at risk. Air conditioning is the leading protective factor against heat-related illness and death. On the coast, the small range in temperature from day to night and from winter to summer produces an unusually equable regime. Watsonville is a coastal city with a mild year-round climate. Average maximum temperatures range from $75^{\circ} \mathrm{F}$ to $77^{\circ} \mathrm{F}$ in August and September,the hottest months of the year.

\section{Hurricanes, Typhoons, and Coastal Storms}

A hurricane is a severe tropical storm that forms in the North Atlantic Ocean, the Northeast Pacific Ocean east of the dateline, or the South Pacific Ocean east of $160^{\circ}$. Hurricanes need warm tropical oceans, moisture and light winds above them. If the right conditions last long enough, a hurricane can produce 
violent winds, incredible waves, torrential rains and floods. In other regions of the world, these types of storms have different names. This is called a typhoon when they occur in the Northwest Pacific. A tropical storm becomes a hurricane when winds reach $74 \mathrm{mph}$. When hurricanes move onto land, the heavy rain, strong winds and heavy waves can damage buildings, trees and cars. The heavy waves are called a storm surge. Storm surges are very dangerous as they threaten low lying coastal lands with inundation. Coastal storms in Santa Cruz County consist of precipitation, occasional high winds and heavy waves. Because the City is not in an area subject to hurricanes, the risks from coastal storms are generally limited to flooding which is discussed separately.

\section{Winter Storms and Hailstorms}

Severe winter storms and weather include extreme cold, heavy snowfall, ice storms, winter storms, and/or strong winds. In addition, winter storms may result in other hazards such as flooding, severe thunderstorms, tornadoes or extreme winds. Snow has been reported in nearly every part of California, but it is very infrequent west of the Sierra Nevada except at high elevations of the Coast Range and the Cascades. The City of Watsonville is in a mild coastal area without risk of heavy snowfall or ice storms.

\section{Volcanoes}

Volcanoes are described as a vent in the Earth's crust through which molten or hot rock, steam, and ash reach the surface, including the cone built by the eruptions. According to the NOAA the only two volcanoes in California which have erupted in the last six hundred years are Mono Lake and Mt. Lassen.Watsonville is over 300 miles from either of these volcanic sites. While there is always a possibility that as a result of an eruption some ash might drift as far as Watsonville. Given the history of eruption and the distance from potential eruption sites, the risk appears to be negligible for Watsonville. 


\subsection{Multi-Hazard Summary}

Any of the hazards that threaten the City of Watsonville could happen in combination with another hazard. In fact, there is a high likelihood that a major earthquake on the San Andreas or other faults would unleash secondary hazards that could be as disastrous to Watsonville as the earthquake itself. A reference point for the Bay Area is the devastating fire in 1906 that burned down San Francisco, causing significantly more destruction than the earthquake that sparked it.

Earthquake shaking can start fires in numerous ways, such as tipping over appliances with pilot lights or damaging electrical equipment leading to sparks. Ruptured gas lines, both underground and where they connect to houses, or spilled flammable chemicals, can cause post-earthquake fires to spread quickly. Efforts to fight fires after an earthquake are often severely hampered by non-functional water systems, damaged electrical systems which are needed to provide energy to pump water, or roads blocked by debris or landslides. These problems coincide with fire personnel being required for search and rescue activities and other disaster response activities. Earthquakes can also trigger other hazards such as levee failure, liquefaction, and the collapse of unreinforced masonry. Seismic activity could damage URM structures, and the risk is increased if the URM structure is located on liquefaction soils. If levees are significantly damaged during an earthquake, flooding could occur which would create a hazard as well as add difficulty to addressing other earthquake-related damage and emergencies.

The next earthquake may cause significant damage to the city’s water supply and storm drain systems. Although the risk is very low, an earthquake has the potential to cause levee failure. Breaks in the levees and stream culverts could lead to catastrophic flooding in areas that have not seen floodwaters previously.

Earthquakes may also induce hazardous materials releases if materials are not stored properly and are disturbed by the seismic activity. 
Although the city water supply is not vulnerable to drought, drought conditions increases the risk of wildfires, and wildfires increase the risk of landslide and flood. The charred surface of the earth becomes hard and absorbs less water during rainfall, leading to increased runoff resulting in more rapid coastal erosion. 


\subsection{Capability Assessment}

The Capability Assessment portion of the mitigation plan identifies technical, legal, and fiscal capabilities for implementing mitigation strategies. This includes a summary of departments and their responsibilities as well as codes, ordinances, and plans already in place associated with hazard mitigation planning.

\subsection{Staff and Organizational Capability: Departmental Responsibilities}

The City of Watsonville operates several departments with capabilities for implementing hazard mitigation strategies. These departments and their roles and responsibilities are summarized below. Recognizing hazards and mitigation strategies relevant to each department can help integrate hazard mitigation implementation with ongoing policies and programs.

\section{Fire Department}

The Watsonville Fire Department serves and protects the City from hazards associated with fire, hazardous materials, and disasters and provides rescue and basic life support for medical emergencies. The department provides programs to prevent and mitigate the threats associated with fire, medical emergencies, hazardous materials, and accidental injury through prevention and public education. The Fire Department is also responsible for managing the City’s safety and disaster management programs, and provides hazardous materials code enforcement, public education and emergency response services for the residents of the City. The Fire Department oversees enforcement of hazardous waste regulations, underground tank requirements, hazardous materials management plans, risk management requirements and clean up of hazardous materials spills that occur within the City (City of Watsonville 2012b). 


\section{Community Development}

The Community Development Department is responsible for the review of development and building activity to ensure compliance with zoning and building codes, General Plan policies, the California Environmental Quality Act, and community values. The department assists the community in establishing land use plans, affordable housing, and ensures the quality of new projects through the development review process. The Department includes the Building Division which interprets codes,

provides plan review and building permits, inspects housing conditions, and facilitates the development of commercial, industrial, and residential uses in the City. The Planning Division formulates and implements broad-reaching planning which serves a variety of needs. The division pursues the goals of the General Plan and provides technical and professional staff support in developmental processing, environmental protection and city and regional planning (City of Watsonville 2012b).

\section{Police Department}

The Watsonville Police Department maintains the public peace, safeguards lives and property, and provides for a quality of life whereby those persons within the City of Watsonville have a sense of security and freedom in their daily lives. The department maintains a viable proactive organization which recognizes and effectively responds to current and future community needs by maximizing the use of available resources, personnel, and technology (City of Watsonville 2012b).

\section{Public Works and Utilities Department}

The Public Works and Utilities Department provides essential infrastructure services to the City of Watsonville. These services include: maintaining roadways, graffiti removal, provision of water and wastewater services, maintenance of City vehicles, and bridge maintenance. Public Works and Utilities operates, maintains, and improves the City’s storm drains. The department is divided into seven divisions: Water and Wastewater, Collections Systems (maintains storm and wastewater systems), Solid Waste, 
Materials Recovery (recycling systems), Engineering (infrastructure including bridges, roadways, water main maintenance), Facilities and Equipment, and Environmental Education (City of Watsonville 2012b).

\section{Watsonville Municipal Airport}

The mission of the airport is to improve the economic viability, safety, and living environment for the community. The airport provides critical links in the event of an emergency and provides daily service for personal, medical and business needs. Watsonville Airport also serves as a base for Civil Air Patrol search and rescue missions (Watsonville Municipal Airport 2001).

\section{Finance Department}

The Finance Department is divided into five divisions which include Information Services, and Geographical Information Systems (GIS). The department is also responsible for the Risk Management Fund under the Internal Service Fund section. The Information Services Division provides support for the mainframe, microcomputing, and telecommunication needs of the City. It assists departments in their use of these resources, as well as other aspects of computing and automation. The GIS Center provides GIS database and map-making services for all City departments, as well as related programs. GIS is used to enhance the availability and presentation of city information (City of Watsonville 2012b).

\section{Parks and Community Services Department}

The City of Watsonville Parks and Community Services Department provides a system of parks and facilities that contribute to the vitality of the community and promote health, well-being and enjoyment for all residents. In the event of an emergency, parks and recreation facilities may be utilized for emergency support (City of Watsonville 2012b). 


\subsection{Technical Capability}

A diverse breadth of staff and technical capabilities is necessary for a successful mitigation program.

Planners, engineers, buildings inspectors, emergency managers, floodplain managers, GIS coordinators, and grant writers are essential to implementing mitigation actions. Table 4.2-1 summarizes the staffing capabilities available within the City of Watsonville. (County Santa Clara 2011)

Table 4.2-1 Technical Capability Matrix

\begin{tabular}{|c|c|c|c|c|c|c|}
\hline $\begin{array}{l}\text { Land Use } \\
\text { Planners }\end{array}$ & $\begin{array}{l}\text { Civil or } \\
\text { Building } \\
\text { Engineers }\end{array}$ & $\begin{array}{l}\text { Emergency } \\
\text { Manager }\end{array}$ & $\begin{array}{l}\text { Floodplain } \\
\text { Manager }\end{array}$ & $\begin{array}{l}\text { Staff } \\
\text { knowledgeable } \\
\text { about hazards }\end{array}$ & GIS Staff & $\begin{array}{l}\text { Grant } \\
\text { Writers }\end{array}$ \\
\hline $\begin{array}{l}\text { Community } \\
\text { Development }\end{array}$ & $\begin{array}{l}\text { Public Works, } \\
\text { Community } \\
\text { Development }\end{array}$ & Public Works & Public Works & $\begin{array}{l}\text { Fire } \\
\text { Department, } \\
\text { Emergency } \\
\text { Services }\end{array}$ & $\begin{array}{l}\text { Geographic } \\
\text { Information } \\
\text { Systems }\end{array}$ & None \\
\hline
\end{tabular}

\subsection{Policy and Program Capability}

The City of Watsonville has several plans and ordinances in place which provide opportunities for implementing the hazard mitigation strategy outlined in this plan. These plans include the following:

Table 4.3-1 Available Plans and Ordinances

\begin{tabular}{|l|l|}
\hline Plan & Implementing Department \\
\hline Capital Improvement Plan & Public Works and Utilities Department \\
\hline Comprehensive Land Use Plan & Community Development Department \\
\hline Emergency Operations Plan & Fire Department \\
\hline Hazardous Materials Plan & County of Santa Cruz Public Health Department \\
\hline Stormwater Management Plan & Public Works and Utilities \\
\hline General Plan & Community Development Department \\
\hline Zoning Ordinance & Community Development Department \\
\hline Subdivision Ordinance & Community Development Department \\
\hline Building Code & Community Development Department \\
\hline Fire Code & Community Development Department \\
\hline Airport Master Plan & Watsonville Municipal Airport \\
\hline Floodplain Management & $\begin{array}{l}\text { Community Development and Public Works and } \\
\text { Utilities Departments }\end{array}$ \\
\hline
\end{tabular}


The plans summarized in this section directly facilitate or encourage hazard mitigation. The plans and programs are briefly described below. Each of these plans is associated with increasing public health and safety of the City of Watsonville and reducing risks and vulnerable populations. These plans are summarized to provide information regarding the existing capabilities of the city and to identify existing plans that may be able to be added to or developed upon to reduce the risk and vulnerability of the city to the risks identified in this plan.

\section{Emergency Operation Plan}

The City Emergency Operation Plan identifies the City’s emergency planning, organization, and response policies and procedures. The plan also addresses the integration and coordination with other governmental departments and how the City will respond to extraordinary events, emergencies or disasters from preparation to recovery. The plan identifies several potential hazards and establishes departmental responsibilities for event response.

\section{City of Watsonville General Plan Land Use and Community Development Element}

The City's Land Use Element illustrates the City’s intentions for physical development, redevelopment, conservation, and growth. It includes the Land Use Diagram that designates and guides the proposed locations and pattern of land use. The City of Watsonville is anticipated to grow steadily in the next 20 to 25 years and strategic development will help manage this growth and realize established goals. The goals of the land use and community development element are as follows:

- Reinforce preservation of surrounding rural character by conservation of agricultural land and open space through encouraging reinvestment in, and higher-density redevelopment of underutilized opportunities within existing urban areas 
- Encourage new residential developments that provide a range of styles, sizes, prices, rents, and locations; and follow the concepts of the City’s Livable Community Residential Guidelines.

- Encourage flexible uses on commercial, industrial, and employment-generating land to maximize efficient development of employment-generating land.

- Encourage efficient development in designated New Growth Areas beyond existing City limits (2004) to help sustain projected City growth.

- Encourage preservation and protection of long established neighborhood qualities.

- Encourage appropriate development on lands best suited for urban uses.

- The City shall remain committed to using the General Plan as the blueprint and guideline for future growth; all new development should be consistent with the General Plan.

- Ensure adequate amount of land for public and quasi-public uses needed to serve City residents.

\section{City of Watsonville General Plan Public Hazards Element}

The City’s Public Hazards Element addresses public security issues and noise control through analysis of conditions and hazards that have the potential to cause loss of life, injury, property damage, economic loss and social dislocation. The goals of the Public Hazards Element are as follows:

- Plan for and regulate the uses of land in order to provide a pattern of urban development that will minimize exposure to hazards from either natural or human-related causes.

- Reduce the potential for loss of life, injury, and economic damage resulting from earthquakes and associated geologic hazards such as landslides and liquefaction.

- $\quad$ Reduce the potential for loss of life and property damage in areas known to be flood prone.

- Ensure that all existing structures in the city area maintained at adequate levels of fire suppression standards, that new structures conform to current fire safety standards, and the coordination is 
maintained between urban and rural fire districts for the prevention and suppression of structural and wildland fires.

- Reduce the potential danger related to the use, storage, transport, and disposal of hazardous materials to an acceptable level of risk for City residents.

- $\quad$ Ensure that community standards for personal safety are enforced.

- Anticipate the potential for disasters, maintain continuity of life-support functions during an emergency, and maximize efforts for post-emergency recovery.

- Evaluate new and existing land uses in the City for compatibility related to noise effects and require, as appropriate, mitigation where harmful effects can be identified and measurable improvements will result.

\section{City of Watsonville Capital Improvement Program Multi-Year Plan (2011-2016)}

To develop the Capital Improvements Program, each department submitted projects for inclusion and to be reviewed by the Community Development Department. The plan was approved by the Planning commission and adopted by the City Council in May 2011. Within the plan, programs and equipment needs are discussed and funding sources are identified and given a timeline.

\section{Watsonville Municipal Airport Master Plan}

The Watsonville Municipal Airport Master Plan is intended to facilitate the orderly, flexible and environmentally sensitive expansion and development of the airport. It is the mission of the airport to improve the economic viability, safety, and living environment for the community. The most recent update of the plan was completed in 2010.

City of Watsonville Urban Water Management Plan 
The 2010 Urban Water Management Plan for the City of Watsonville informs on the present and future water demands and supplies for the City and assesses the City's water resource needs. The UWMP will guide efficient use of water supplies, evaluation of water supplies and demand, and conservation programs and policies. The plan also sets strategies for responding to water shortages and drought conditions (City of Watsonville 2010a).

\section{County of Santa Cruz Local Hazard Mitigation Plan}

The Santa Cruz County Local Hazard Mitigation Plan is intended to assist the County in reducing its risk from all hazards by identifying resources, information, and strategies for risk reduction. The plan also guides and coordinates mitigation activities throughout the County. Identifying potential sources for cooperation and mutual aid between the County and City can be mutually beneficial.

\section{Flood Control Planning}

In addition to plans and programs associated with City operation, the City of Watsonville has been engaged in planning for flood protection. The levees within the City are under the management and jurisdiction of several agencies and many studies and plans have been developed to increase the stability and flood protection of the levees. As identified in the risk assessment, there is a high risk of flooding in the City and surrounding areas. Mitigation can be more effective if it is building upon existing efforts and plans and working within the established framework and planning process for the levees. Due to the interjurisdictional nature of the Pajaro Valley watershed, and the variety of water quality, supply and flooding issues that are of concern, many projects and plans have been developed. The plans discussed in Table 4.3-2 either primarily or in part, address flood control in Watsonville. Selected plans, programs and agencies relating to levee control are discussed below. 
Table 4.3-2 Projects Addressing Flood Control in the City of Watsonville

\begin{tabular}{|l|l|l|l|}
\hline Project Title & Project Action & Managing Agency & $\begin{array}{l}\text { Intended Flood Protection } \\
\text { Result for the City of } \\
\text { Watsonville }\end{array}$ \\
\hline $\begin{array}{l}\text { Soap Lake Preservation } \\
\text { Project }\end{array}$ & $\begin{array}{l}\text { Preservation of } \\
\text { agriculture land in the } \\
\text { Soap Lake Floodplain }\end{array}$ & $\begin{array}{l}\text { Pajaro River Watershed } \\
\text { Flood Prevention } \\
\text { Authority }\end{array}$ & $\begin{array}{l}\text { Reduces the flow of water that } \\
\text { would reach the lower Pajaro } \\
\text { River }\end{array}$ \\
\hline $\begin{array}{l}\text { Levee Reconstruction } \\
\text { Project }\end{array}$ & $\begin{array}{l}\text { Excavate existing benches } \\
\text { and reconstruct existing } \\
\text { levee system }\end{array}$ & $\begin{array}{l}\text { Santa Cruz County, } \\
\text { Monterey County, U.S. } \\
\text { Army Corps of Engineers, } \\
\text { Action Pajaro Valley }\end{array}$ & $\begin{array}{l}\text { Increase levee flow capacity } \\
\text { from 22,000 cfs to 44,000 cfs } \\
\text { (conveyance of the 100-year } \\
\text { flood event). }\end{array}$ \\
\hline $\begin{array}{l}\text { ALERT Station } \\
\text { Monitoring }\end{array}$ & $\begin{array}{l}\text { Install additional flood } \\
\text { warning stations in the } \\
\text { Pajaro River Watershed } \\
\text { Monterey County Water } \\
\text { Resources Agency, City } \\
\text { of Watsonville }\end{array}$ & $\begin{array}{l}\text { Enhance flood forecasting } \\
\text { capabilities, increase } \\
\text { knowledge of flooding issues, } \\
\text { permit flood control project } \\
\text { performance evaluation. }\end{array}$ \\
\hline $\begin{array}{l}\text { San Juan Basin Surface } \\
\text { Drainage }\end{array}$ & $\begin{array}{l}\text { Provide surface water } \\
\text { detention and drainage } \\
\text { alternatives to the San } \\
\text { Juan Basin }\end{array}$ & SCVWD & $\begin{array}{l}\text { Reduce peak flows from the } \\
\text { San Juan Basin into the Pajaro } \\
\text { River. }\end{array}$ \\
\hline $\begin{array}{l}\text { Pajaro River Watershed } \\
\text { Study }\end{array}$ & $\begin{array}{l}\text { Gain better understanding } \\
\text { of watershed issues and } \\
\text { identify flood control } \\
\text { measures }\end{array}$ & $\begin{array}{l}\text { Pajaro River Watershed } \\
\text { Flood Protection Agency }\end{array}$ & $\begin{array}{l}\text { Reduce flooding of the Pajaro } \\
\text { River. }\end{array}$ \\
\hline $\begin{array}{l}\text { Lower Pajaro River } \\
\text { Enhancement Plan }\end{array}$ & \multicolumn{2}{l}{$\begin{array}{l}\text { Santa Cruz County } \\
\text { Resource Conservation } \\
\text { District }\end{array}$} & \\
\hline
\end{tabular}

Table 4.3-3 Plans Associated With the Integrated Regional Water Management Plan

\begin{tabular}{|l|c|l|l|}
\hline Document & $\begin{array}{l}\text { Publication } \\
\text { Date }\end{array}$ & Agency/Entity & Relation to IRWMP \\
\hline $\begin{array}{l}\text { City of Watsonville General } \\
\text { Plan }\end{array}$ & 2005 & City of Watsonville & $\begin{array}{l}\text { Provides list of city's policies, goals, and } \\
\text { actions for land use and flood control. }\end{array}$ \\
\hline $\begin{array}{l}\text { City of Watsonville Urban } \\
\text { Water Management Plan } \\
\text { (UWMP) }\end{array}$ & 2006 & City of Watsonville & $\begin{array}{l}\text { Provides understanding of Watsonville } \\
\text { urban water needs, management and } \\
\text { planning objectives. }\end{array}$ \\
\hline $\begin{array}{l}\text { Biological Assessment } \\
\text { Pajaro River and } \\
\text { Salsipuedes and Corralitos } \\
\text { Creeks Management and } \\
\text { Restoration Plan }\end{array}$ & 2001 & County of Santa Cruz & $\begin{array}{l}\text { Provides understanding of biological and } \\
\text { restorative plans within the Pajaro River. }\end{array}$ \\
\hline $\begin{array}{l}\text { Pajaro River Watershed } \\
\text { Study Reports (Phases I, II, } \\
\text { III, IV) }\end{array}$ & $2002-2005$ & $\begin{array}{l}\text { Pajaro River Watershed } \\
\text { Flood Prevention Authority }\end{array}$ & \\
\hline $\begin{array}{l}\text { Pajaro River Watershed } \\
\text { Water Quality Management } \\
\text { Plan }\end{array}$ & 1999 & $\begin{array}{l}\text { Association of Bay Area } \\
\text { Governments }\end{array}$ & $\begin{array}{l}\text { States AMBAG water quality } \\
\text { management goals. }\end{array}$ \\
\hline
\end{tabular}




\begin{tabular}{|c|c|c|c|}
\hline $\begin{array}{l}\text { Revised Basin Management } \\
\text { Plan } \\
\text { (BMP) }\end{array}$ & 2002 & $\begin{array}{l}\text { Pajaro Valley Watershed } \\
\text { Management Agency }\end{array}$ & $\begin{array}{l}\text { The Revised Basin Management Plan } \\
\text { address the issues of seawater intrusion, } \\
\text { water supply and water recycling, all of } \\
\text { which have been identified as high } \\
\text { priority issues for the City. }\end{array}$ \\
\hline $\begin{array}{l}\text { Salsipuedes Creek } \\
\text { Maintenance Analysis (File } \\
\text { \#50275) }\end{array}$ & 2000 & Central Coast RWQCB & $\begin{array}{l}\text { Provides understanding of the surface- } \\
\text { and } \\
\text { groundwater quality objectives of the } \\
\text { Central } \\
\text { Coast RWQCB. }\end{array}$ \\
\hline $\begin{array}{l}\text { Pajaro River Bench } \\
\text { Excavation Analysis (1 and } \\
\text { 2) }\end{array}$ & 2004 & $\begin{array}{l}\text { Santa Cruz County Flood } \\
\text { Control and Conservation } \\
\text { District Zone } 7\end{array}$ & \\
\hline $\begin{array}{l}\text { Pajaro River Bench } \\
\text { Excavation Project, Tree } \\
\text { Resource } \\
\text { Evaluation/Sediment } \\
\text { Excavation Impact } \\
\text { Assessment }\end{array}$ & 2005 & $\begin{array}{l}\text { Santa Cruz County Public } \\
\text { Works Department }\end{array}$ & \\
\hline $\begin{array}{l}\text { File \#50275; Memo, RE: } \\
\text { Pajaro River Bench } \\
\text { Excavation Analysis }\end{array}$ & 2004 & $\begin{array}{l}\text { Santa Cruz County Flood } \\
\text { Control and Conservation } \\
\text { District Zone } 7\end{array}$ & $\begin{array}{l}\text { Technical analysis of Pajaro River } \\
\text { Bench Excavation Project }\end{array}$ \\
\hline $\begin{array}{l}\text { Soap Lake Floodplain } \\
\text { Preservation Project- Draft } \\
\text { Initial Study and Negative } \\
\text { Declaration }\end{array}$ & 2004 & $\begin{array}{l}\text { Pajaro River Watershed } \\
\text { Flood Prevention Authority }\end{array}$ & \\
\hline $\begin{array}{l}\text { Pajaro River Flood Control } \\
\text { Project Alternative } \\
\text { Formulation Briefing } \\
\text { Document (F4a Milestone) }\end{array}$ & 2004 & $\begin{array}{l}\text { USACE, San Francisco } \\
\text { District }\end{array}$ & \\
\hline $\begin{array}{l}\text { Pajaro River Bench } \\
\text { Excavation Analysis } 1 \text { (File } \\
\# 50275 \text { ) }\end{array}$ & 2004 & $\begin{array}{l}\text { Santa Cruz County Flood } \\
\text { Control and Conservation } \\
\text { District Zone } 7\end{array}$ & \\
\hline $\begin{array}{l}\text { Pajaro River Stable } \\
\text { Planform Study- Pajaro } \\
\text { River Channel Planform and } \\
\text { Channel Forming Discharge } \\
\text { Analysis } \\
\end{array}$ & 2003 & USACE & $\begin{array}{l}\text { Recommendations regarding lowering } \\
\text { bench elevation as one of four methods } \\
\text { proposed for resorting the Pajaro River } \\
\text { channel to its original bankfull } \\
\text { dimensions. }\end{array}$ \\
\hline $\begin{array}{l}\text { Final EIR Pajro River and } \\
\text { Salsipuedes and Corralitos } \\
\text { Creeks Management and } \\
\text { Restoration Plan }\end{array}$ & 2002 & County of Santa Cruz & \\
\hline $\begin{array}{l}\text { Draft- Pajaro Valley Water } \\
\text { Management Agency } \\
\text { Revised Basin Management } \\
\text { Plan EIR }\end{array}$ & 2001 & PVWMA & \\
\hline
\end{tabular}


Santa Cruz County Flood Control and Water Conservation District, Zone 7 (SCCFC\&WCD)

The Santa Cruz County Flood Control and Water Conservation District Zone 7 is area within Santa Cruz County governed by the Santa Cruz County Board of Supervisors, the City of Watsonville, and PVWMA. The District provides flood control services to Santa Cruz County and the City of Watsonville. The District has been in coordination with the U.S. Army Corps of Engineers and the County of Monterey (Monterey County Water Resources Agency, Zones 1 and 1A) to develop and implement a Levee Reconstruction Project on the Pajaro River.

\section{City of Watsonville Stormwater Management Plan}

The stormwater management plan informs on the status of goals, evaluation of BMP's and their effectiveness, and informs revisions to BMP's or on measureable goals. The latest update of the plan was completed in 2009 by the City of Watsonville.

\section{Pajaro River Watershed Flood Protection Agency}

The Pajaro River Watershed Flood Protection Agency is a state-formed special district to identify, evaluate, fund, and implement flood prevention and control strategies in the Pajaro River Watershed on an intergovernmental basis. The PRW FPA conducted a Pajaro River Watershed Management Plan (in four phases, from 2002 to 2005) to establish an understanding of the watershed and the elements that impact the flooding potential of the river, to identify alternatives to address flooding, select appropriate projects and perform environmental impact analysis, and to implement flood protection projects.

\section{Water Resources Management Plan for Watsonville Slough System}

The slough system management plan informs on the hydrologic and water quality conditions and pollution sources of the slough and establishes measures to improve water quality and wetland management. The plan was completed by the Association of Monterey Bay Area Governments in 1995. 


\section{$\underline{\text { Pajaro River Watershed Collective }}$}

The Pajaro Valley Water Management Agency is a collaborative effort by the Pajaro Valley Water Management Agency (PVWMA), San Benito County Water District (SBCWD), and Santa Clara Valley Water District (SCVWD) to identify regional and multi-beneficial projects for the Pajaro River Watershed. "The mission of the Pajaro River Watershed Collaborative is to preserve the economic and environmental health and well-being for the Pajaro River watershed through watershed stewardship and comprehensive management of water resources in a practical, cost effective and responsible manner.”

In order to identify and address regional and multi-beneficial projects for the watershed, the Collective developed the Pajaro River Watershed Integrated Regional Water Management Plan. This plan identified water quality, water supply, flood protection, and environmental protection and enhancement as four key goals to address.

\section{Pajaro River Watershed Integrated Regional Water Management Plan}

The PRW IRWMP presents the region's water resources management objectives and recommends four water management programs for addressing the highest priority needs. These programs include a Conjunctive Water Supply Management, Water Supply/ Salt Management, Agricultural Water Quality, and Pajaro River Watershed Flood Protection.

\section{Pajaro River Flood Protection Program}

The flood protection goal of the IRWMP is to ensure flood control strategies are developed and implemented in a watershed-wide approach and are designed to maximize opportunities for comprehensive water resource management. The Pajaro River Flood Protection Program was developed to prevent flood damage to homes, businesses and agriculture lands along the Pajaro River. The program capitalizes on opportunities to address multiple objectives including environmental restoration, economic development, and appropriate public access and use of the Pajaro River corridor. Implementation of the 
program will maximize opportunities for habitat restoration, open space and recreation benefits in conjunction with offering flood management benefits. The program involves joint efforts by multiple agencies and stakeholders coordinating across jurisdictions to develop the most effective and acceptable solutions possible. In addition to ensuring the maintenance of the natural floodplain hydrologic, hydraulic and geomorphic characteristics and sediment issues of the river, the Pajaro River Flood Protection Program will ensure flood prevention measures will protect life, agricultural industries, resources, and disadvantaged and low income communities.

The primary objectives of the Pajaro River Flood Protection program are:

- Implement flood protection projects throughout the watershed that provide multiple benefits

- Reach consensus on the Pajaro River Flood Protection Project necessary to protect existing infrastructure and land uses from flooding and erosion from the 100-year event

- Work with stakeholders to preserve existing flood attenuation by implementing land management strategies throughout the watershed

- Develop approaches for adaptive management to minimize maintenance requirements and protect quality and availability of water while preserving ecologic and stream functions.

- Provide community benefits beyond flood protection such as public access, open space, recreation, agriculture preservation and economic development.

The high priority projects fundamental to the base of the Pajaro River Flood Protection program are:

- Pajaro River Watershed Study

- $\quad$ Soap Lake Floodplain Preservation Project

- $\quad$ San Juan Basin Surface Drainage 
The lower priority projects which have been integrated into the Pajaro River Flood Protection program are:

- ALERT Station Monitoring

- Levee Reconstruction Project

- Lower Llagas Creek Flood Protection Project

The environmental enhancements identified for the Pajaro River Flood Protection program are:

- Historic Ecological Study of the Upper Pajaro

- Open Space Authority Acquisitions

- Pajaro River Parkway

- $\quad$ Restoration of the Upper Pajaro River Floodplain

- $\quad$ San Benito River Parkway

- Trails, Parks, and Open Space Grants 


\subsection{Summary of Relevant Ordinances}

The City of Watsonville has several ordinances and policies to mitigate hazards. The California Building Code, which is based on Volumes I and II of the 2009 International Building Code, is adopted as the Building Code for the City of Watsonville. The California Building Code (CBC) provides for the mitigation of seismic hazards to structures. Title 4, Chapter 2 of the Municipal Code provides for the protection of persons and property in the event of an emergency and the coordination of emergency functions.

Title 9 of the City Building Code regulates development in the flood plain and requires that structures built within the flood plain are elevated a foot above the base flood elevation. The Community Development Department administers this ordinance.

The zoning and subdivision ordinances of the city restrict development within protected watershed areas and the fire code restricts building development which could increase the potential for fire within the city.

\subsection{Federal Programs}

For decades, the national response to flood disasters was to provide disaster relief to flood victims. Funded by citizen tax dollars, this approach failed to reduce losses and didn't provide a way to cover the damage costs of all flood victims. To compound the problem, the public generally couldn't buy flood coverage from insurance companies, because private insurance companies consider floods too costly to insure. In the face of mounting flood losses and escalating costs of disaster relief to U.S. taxpayers, Congress established the National Flood Insurance Program (NFIP). The goals of the program are to reduce future flood damage through floodplain management, and to provide people with flood insurance. 
Community participation in the NFIP is voluntary and the City of Watsonville is currently participating in the program. All residents of the City are eligible to purchase federal flood insurance. The City continues to maintain full compliance with the NFIP (County of Santa Clara 2011).

\section{Community Rating System (CRS)}

The CRS is a voluntary part of the National Flood Insurance Program that seeks to coordinate all floodrelated activities, reduce flood losses, facilitate accurate insurance rating, and promote public awareness of flood insurance by creating incentives for a community to go beyond minimum floodplain management requirements. The incentives are in the form of insurance premium discounts. CRS ratings are on a 10point scale (from 10 to 1 , with 1 being the best rating), with residents of the community who live within FEMA’s Special Flood Hazard Areas (SFHA) receiving a 5\% reduction in flood insurance rates for every Class improvement in the community’s CRS rating. The City of Watsonville is currently in the Community Rating System with a “7” rating and a "Current” status (National Flood Insurance Program 2011). All insurance rates are based on where the structure is located in FEMA’s Flood Insurance Rate Maps (FIRMs). The most recent Digital FIRMs are anticipated to be adopted by the City in the spring of 2012 (County of Santa Clara 2011).

\section{Repetitive Loss Properties}

The Federal Emergency Management Agency (FEMA) insures properties against flooding losses through the National Flood Insurance Program. As part of the process to reduce or eliminate repetitive flooding to structures across the United States, FEMA has developed an official Repetitive Loss Strategy. The purpose behind the national strategy is to identify, catalog, and propose mitigation measures to reduce flood losses to the relatively few number of structures that absorb the majority of the premium dollars 
from the national flood insurance fund. A repetitive loss property is defined by FEMA as "a property for which two or more National Flood Insurance Program losses of at least \$1,000 each have been paid within any 10-year period since 1978.” The City of Watsonville has 79 repetitive flood loss properties, and a total of $\$ 704,314$ has been paid on losses (County of Santa Clara 2011, NFIP 2011). 


\subsection{Mitigation Recommendations}

The following mitigation measures are recommended to address the risk and vulnerabilities of natural and human-caused hazards identified in the risk and vulnerabilities assessment. The mitigation measures identified here are recommendations intended for further discussion and development by the City.

This plan focuses on mitigation, or actions that occur prior to a hazard event that reduce or avoid damage during a hazard event. Such measures include structural improvements to existing structures, land use decisions that minimize damage, and ongoing programs to reduce increase resiliency. This plan does not include emergency response activities as those are included in the city’s Emergency Action Plan which coordinates information and resources for disasters.

The mitigation goals and objectives identified in this section were adopted as the goals and objectives for the Public Safety and Noise Element of the General Plan. Further discussion or development of mitigation goals and objectives specific to the Local Hazard Mitigation Plan is encouraged. Development of the mitigation plan will require identification and prioritization of measures, and the identification of the parties responsible for implementation, the funding sources and timeline of action.

These measures are intended to address specific issues identified in the risk and vulnerability assessment, as well as measures adopted in the Public Hazards and Noise Element of the General Plan, and measures implemented in other jurisdictions. This is an extensive list that the City may prioritize and select the most efficient, effective, and feasible measures.

Selection of mitigation measures should represent a variety of methods to reduce risk and vulnerability to the city. Measures may range from "everyday operations”, to updating critical facilities or infrastructure, 
to implementing broader, long-range programs to reduce risk. A number of critical facilities are outside of the city limits and require coordination with other jurisdictions to mitigate their vulnerability. The mitigation strategy should reflect the range of coordination necessary to fully mitigate vulnerability. This may require a tired mitigation strategy, where mitigation is divided into measures the city can take directly, measures the city will need to coordinate with another jurisdiction, and measures another agency or jurisdiction would need to undertake, but the city would support.

FEMA guidance suggests that mitigation measures be decided upon based on consideration of social, technical, administrative, political, legal, economic, and environmental factors. The acronym STAPLE(E) outlines the following issues that should be considered for the mitigation strategy:

- $\quad$ Social: Is the strategy socially acceptable?

- Technical: Is the proposed action technically feasible, cost effective, and does it provide the appropriate level of protection?

- Administrative: Does the community have the capability to implement the action, and is the lead agency capable of carrying out oversight of the project?

- Political: Is the action politically acceptable?

- Legal: Does the community have the authority to implement the proposed action?

- Economic: Doe the economic base, projected growth, and opportunity costs justify the project? If the benefits are greater than the costs, is the project cost-effective?

- Environmental: Does the proposed action meet statutory considerations and public desire for sustainable and environmentally healthy communities? 
Identified mitigation measures should be prioritized in order for resources to be responsibly allocated and so that urgent needs may be addressed without compromising lesser priorities. It is suggested that measures are prioritized based on the risk of the hazard they address. Prioritization may also be based on the identified loss estimates or critical facility vulnerabilities. Available funding or difficulty of implementation may also be a factor in prioritization. The level of public support for an action or a hazard may also influence the prioritization of mitigation measures.

The following prioritization criteria were developed by the County of Santa Cruz and may serve as guidance to the City of Watsonville:

\section{Very High Priority}

- A project that meets multiple plan objectives

- $\quad$ Benefits exceed cost

- Has strong community support

- Addresses those hazards presenting the highest risk

- Funds are identified or potentially available

- Project can be completed in one to five years once project is funded

High Priority

- Project meets at least one plan objective

- Benefits exceed costs

- Funding has not been secured

- Project can be completed in one to five years once project is funded 


\section{Important}

- Project mitigates the risk of a hazard

- Benefits exceed costs

- Funding has not been identified and/or timeline for completion is considered long-term (five to ten years)

Prioritization of mitigation measures may also include consideration of the costs associated with the action or program. Costs and benefits may be considered based on the following guidance:

High: Existing funding levels are not adequate to cover the costs of the proposed project and would require an increase in revenue through an alternative source to implement

Medium: The project could be implemented with existing funding but would require a re-apportionment of the budget or a budget amendment, or the cost of the project would have to be spread over multiple years.

Low: The project could be funded under the existing budget. The project could be a part of an existing program.

Benefits of each mitigation action may also be prioritized based on identified benefit. Benefit may be considered by the following criteria:

High: The project would have an immediate impact on the reduction of risk exposure to life and property.

Medium: The project would have a long-term impact on the reduction of risk exposure to live and property or the project would provide an immediate reduction in the risk exposure to property. 
Low: The long-term benefits of the project would be difficult to quantify in the short-term.

Many mitigation activities reduce risk from more than one hazard. However, there are some mitigation activities that reduce risk from one possible threat while increasing it from another. One example is placing utility lines underground. Underground utilities are less damaged by a major fire than those aboveground. However, in an earthquake, underground utilities in areas prone to landslides or liquefaction are susceptible to damage and are more costly and time-consuming to repair than aboveground utilities. Another example of a mitigation activity with positive and negative impacts is vegetation removal for wildfire risk reduction. Trees and other established plants play a key role in securing hillsides and reducing landslide risk. They also reduce erosion and slow rain runoff time, which reduces flood peaks. It is important to remember all of the implications of any risk reduction steps when planning mitigation activities (County of Santa Cruz 2010).

\subsection{Goals}

The goals listed below were previously developed by the City for the Public Hazards Element of the General Plan. The forthcoming General Plan Update may revise these goals and they are provided here as a guideline of past City policy directive. The goals for the Local Hazard Mitigation Plan may be the same as those listed in the General Plan and should certainly be complementary. Goals for the Local Hazard Mitigation Plan will guide policy decisions for the City in respect to hazards and mitigation measures and should consider future planning and protection visions for the City. 
- Plan for and regulate the uses of land in order to provide a pattern of urban development that will minimize exposure to hazards from either natural or human-related causes.

- The City shall plan for and maintain development standards that minimize risks to human lives and property resulting from environmental and human-caused hazards.

- The City shall protect neighboring residential development from the immediate threats of potentially hazardous industrial or agricultural materials and airport hazards through careful land use planning.

\subsection{Objectives}

The objectives listed below were previously developed by the City for the Public Hazards Element of the General Plan. The forthcoming General Plan Update may revise these goals and they are provided here as a guideline of past City policy directive. The objectives for the Local Hazard Mitigation Plan should reflect established goals and should further develop a means for reaching established goals. Mitigation objectives may be developed either for the entire mitigation strategy or by specific hazard.

- The City shall take all appropriate actions to ensure that current land use activities and new developments are mitigated to prevent soil failure and other soil-related dangers.

- Reduce the potential for loss of life, injury and economic damage resulting from earthquakes and associated geologic hazards such as landslides and liquefaction. 
- Reduce the potential for loss of life and property damage in areas known to be flood prone.

- Ensure all existing structures in the city are maintained at adequate levels of fire suppression standards, that new structures conform to current fire safety standards, and the coordination is maintained between urban and rural fire districts for the prevention and suppression of urban, industrial, and wildfires.

- $\quad$ Reduce the potential danger related to the use, storage, transport and disposal of hazardous materials to an acceptable level of risk for the City residents.

- Provide sufficient funding, adequate personnel levels, and necessary equipment to maintain civil order and prevent crime.

- Maintain critical public services during emergency situations.

\subsection{Identification of Actions}

In order to develop a mitigation strategy, the City will need to identify actions to address identified risk and hazards. These actions should follow the directive of the established goals and objectives for the mitigation strategy and should be able to be implemented by the City.

Due to the size of the city, the varying service areas served by the city, and the number of non-contiguous areas of the city, the City of Watsonville does not have direct jurisdiction over particular facilities that 
may impact the vulnerability of the city. It is recommended that a tiered approach be given to mitigation measures: measures that can be directly facilitated by the City, measures that the City may approach in cooperation with another jurisdiction, and measures that will need to be fulfilled wholly by another jurisdiction but that the City may have input into.

The following mitigation measures are intended for discussion by the City for potential development of a mitigation and implementation strategy. Once mitigation measures are identified, an implementation strategy of how the measure will be undertaken should be developed.

\section{Earthquake Hazard}

\section{Potential Actions}

- Establish a seismic retrofit program to address seismic vulnerability of critical structures.

- Develop and maintain building codes in new development which increase building resiliency to seismic activity.

- Continue public education/outreach for earthquake preparedness.

- Maintain earthquake preparedness and emergency response preparedness.

- Retrofit historic sites for seismic resiliency.

- Conduct targeted seismic education and outreach to daycare facilities.

- Integrate seismic resiliency of infrastructure into maintenance of underground facilities.

- Identify seismically unsound schools for seismic retrofits.

- Upgrade roadways, sewer, water and other infrastructure to withstand seismic shaking.

- Promote seismic safety upgrade of all emergency use and critical structures.

- Train appropriate plan check staff on seismic requirements for structures.

- Use the development review process to ensure that potential geologic hazards are evaluated and mitigated prior to construction of new facilities. 
- Update current seismic hazard zone maps as new information becomes available and use those maps in the development and application of an environmental constraint matrix to evaluate proposed building sites.

\section{Fire Hazard}

\section{Potential Actions}

- Incorporate defensible space requirements for new development in wildfire hazard zones.

- Coordinate with County building departments to reduce wildfire hazards for new development in Measure U areas.

- Develop a fire safety retrofit program for older buildings to require fire suppression and alarm systems.

- Encourage sites with older structures for redevelopment or infill development to reduce the amount of vulnerable structures to urban fire.

- Introduce requirements for industrial building fire alarm and suppression measures.

- Develop practices to reduce fire in vacant industrial buildings.

- $\quad$ Update fire hazard zone mapping with CalFire.

- $\quad$ Reduce fire risk by advocating the use of improved building materials and appropriate code enforcement including defensible space and fuel reduction programs.

- Implement additional fire prevention programs through inspections and education.

- Promote built-in fire extinguishing systems and fire alarm systems in new and existing structures.

- Advocate for the creation of secondary road access improvement.

- Upgrade existing alleyways for emergency access, street addressing, and available water supply.

- Continue to develop and conduct fire safety and prevention public outreach and education programs. 


\section{Flood Hazard}

\section{Potential Actions}

- Secure funding for levee engineering upgrades.

- Coordinate with County Zone 7 to establish levees as a top priority for action.

- Continue to enforce flood resiliency measures for structures in the floodplain.

- Analyze critical facility operation impacts during flooding and develop appropriate mitigation

- Provide incentives for repetitive loss and other flood-prone property owners to retrofit homes to be safe from flooding.

- Continue participation in the Community Rating system to improve floodplain management.

- Continue to inspect and maintain drainage system infrastructure.

- Develop and circulate public education materials on flood protection and mitigation.

- Regulate development in flood plains to optimize preservation of open space.

- Limit development and monitor conditions of development and grading permits near natural channels and wetlands to prevent sedimentation.

- Require new development to conform to the Flood Damage Prevention Ordinance and the guidelines of the National Flood Insurance Program.

- Condition new development to provide for onsite retention and percolation of storm water runoff.

- Require new development to pay for or extend all necessary storm drains to serve the project site.

- Pursue planning and financial support for the improvement of flood conditions along Corralitos and Salispuedes Creeks, the Pajaro River, and other areas of the drainage basin impacting Watsonville in coordination with Santa Cruz Water Conservation District Zone 7. 


\section{Hazardous Materials}

\section{Potential Actions}

- Incorporate structural, handling, and storage requirements for small scale hazardous materials.

- Require fire alarm/suppression measures for all structures handling or storing hazardous materials.

- Review City/County standards for hazardous materials storage and handling and modify to improve safety as needed.

- Streamline communication between County Department of Public Health and City emergency response and planning departments.

- Conduct public education programs on the safe use, storage, and disposal of hazardous materials

- Develop area evacuation plans or public notification plans to protect public health and safety in the event of a hazardous materials release.

\section{Subsidence}

\section{Potential Actions}

- Prepare an analysis of the potential for subsidence to occur and the location of the risk.

- Integrate subsidence potential locations into zoning and building codes to limit growth or apply in those areas.

- Integrate evaluation for subsidence into plan site review for identified vulnerable areas.

- In the event that current practices could influence future subsidence (groundwater pumping, etc), develop measures to reduce such practices.

- Require a soils investigation report prior to new development on sites with a potential to have a high potential for soil-related constraints. 
- Require a geotechnical report prepared by a registered professional prior to the issuance of a building permit in areas that are susceptible to subsidence.

\section{Landslide}

\section{Potential Actions}

- Implement actions in plan review to identify potential areas for landsliding.

- For sites which have the potential for landsliding, impose structural mitigation measures to reduce risk (or limit development in such areas).

- Include landslide strengthening measures to critical infrastructure during maintenance.

- Coordinate with other agencies (Santa Cruz County, CalTrans, etc.) to ensure City critical facilities outside of the city limits are secured from landslide risk.

- Require development review in areas suspected of landsliding and require engineering geology reports when landsliding is identified or suspected.

- Require a soils investigation report prior to new development on sites deemed to have a high potential for soil-related constraints.

- Limit development on soils which are subject to landslide or on slopes greater than $25 \%$.

- Require that soil grading blend with natural topography and that final cut slopes shall be no steeper than $33 \%$.

- Require a geotechnical report prepared by a registered professional prior to the issuance of a building permit in areas that are susceptible to landsliding. 


\section{Liquefaction}

\section{Potential Actions}

- Ensure that future emergency response critical facilities are built to be resistant to liquefaction through structural modifications.

- Apply liquefaction resistant elements to major underground infrastructure.

- Require structural methods to increase resistance to liquefaction to new large structures or large assembly structures.

\section{Unreinforced Masonry}

\section{Potential Actions}

- $\quad$ Prioritize existing URM structures for retrofit.

- Work with owners of URM structures to retrofit all URM structures.

- Provide information to owners on retrofit requirements.

- Require retrofit of URM buildings (on high priority structures, require by date, or during any structural improvements).

- Identify incentives the city can offer for retrofits such as decreasing permit fees or providing priority permitting.

- Evaluate historic structures for URM retrofits. 


\section{Airport Hazard}

\section{Potential Actions}

- Coordinate with the County of Santa Cruz to remove identified trees that create an airport risk.

- Incorporate mitigation identified in the Airport Master Plan into City maintenance and operations.

\section{Civil Disturbance/Terrorism}

\section{Potential Actions}

- $\quad$ Secure infrastructure from vandalism.

\section{Dam Failure}

\section{Potential Actions}

- Develop a communication strategy with upstream dam operators to ensure appropriate emergency communication.

- Develop an event protocol with the State Division of Safety of Dams.

\section{Drought}

\section{Potential Actions}

- Continue to implement water conservation measures to maximize the use of existing water supplies.

\section{Expansive Soils}

\section{Potential Actions}

- Record the impacts of expansive soils in the city to monitor risk to the city.

- Establish the extent of damage that would require structural upgrades.

- Continue to require soil reports as part of the building permit process. 
- Develop design criteria for areas of known expansive soils.

- Require a soils investigation report prior to new development on sites deemed to have a high potential for soil-related constraints.

\section{Natural Gas Pipeline Failure}

\section{Potential Actions}

- Coordinate with PG\&E to ensure natural gas transmission pipeline in the city is in good condition and does not present a risk to the City.

- Coordinate with PG\&E to ensure natural gas transmission and distribution pipelines are resilient to seismic activity.

- Coordinate with PG\&E to ensure natural gas transmission pipelines are resilient to liquefaction.

\section{Tornado}

\section{Potential Actions}

- Coordinate with the County of Santa Cruz to underground appropriate utilities.

\section{Tsunami}

\section{Potential Actions}

- Periodically review tsunami inundation area mapping to ensure that sea level rise impacting the relation of the inundation area to the city.

\section{Vehicle Collision}

\section{Potential Actions}

- Evaluate previous occurrences of vehicle collisions to determine reasons and appropriate mitigation measures to reduce future incidences. 


\section{Additional Measures to Consider}

GIS Multi-Hazard Disaster Management Information System

Enhance the dissemination of risk data

Develop a debris management plan for all hazards

Enhance post-disaster damage inspections to include mitigation strategies

Conduct critical facility audits

Enhance floodplain management ordinance

Increase GIS capabilities within the fire department

Plan for climate change by developing a Climate Action or Adaptation Plan

\subsection{Developing an Implementation Strategy}

The implementation strategy will be supported first by the identification of funding sources, the implementing department, the cost, and a timeline for each action. Reduction of risk and vulnerability is dependent upon implementation of identified mitigation measures. Furthermore, implementation is more likely to be conducted if the mitigation measures are incorporated into exiting city plans, programs, and operation.

The information within this LHMP was developed based on the Public Hazards Element of the General Plan. These two plans may be viewed as working to complement each other to ultimately reduce risk and vulnerability of the city. The mitigation measures identified in this LHMP may be incorporated into the following plans and programs either through amendment or through the scheduled update process: 
- Capital Improvement Program

- City of Watsonville Building Codes

- Community design guidelines

- Water management guidelines

- Storm Water Management Program

In addition to regulation, action items may be implemented through the creation of educational programs, continued interdepartmental and interagency coordination, or increased public participation. 
APPENDIX A

HISTORIC SITES OF INTEREST 


\section{Historical Sites Of Interest}

\begin{tabular}{|c|c|c|}
\hline NAME & ADDRESS & YEAR_BUILT \\
\hline SC Rodgers Home & 107 E Beach St & $1870-1890$ \\
\hline $\begin{array}{l}\text { Josephine Brumson } \\
\text { Home }\end{array}$ & 124 E Beach St & 1893 \\
\hline Vicky's Produce & 129 E Beach St & 1940 's \\
\hline $\begin{array}{l}\text { Van } \\
\text { Doren-Rogers-Daley } \\
\text { House }\end{array}$ & 134 E Beach St & 1870 's \\
\hline George Seitz Home & 265 E Beach St & 1896 \\
\hline $\begin{array}{l}\text { Charles Palmtag } \\
\text { Home }\end{array}$ & 316 E Beach St & 1897 \\
\hline $\begin{array}{l}\text { Waters/Rupert } \\
\text { House }\end{array}$ & $335 \mathrm{E}$ Beach St & $1870-1890$ \\
\hline Saxon Pope Home & 401 E Beach St & 1904 \\
\hline $\begin{array}{l}\text { County of SC } \\
\text { Human Resources }\end{array}$ & 119 W Beach St & $1945-1950$ \\
\hline Henry Wiley Home & 143 W Beach St & 1892 \\
\hline 10 Bonita Terrace & 10 Bonita Terrace & $1950-1970$ \\
\hline Edgar Clark Home & 40 Brennan St & 1905 \\
\hline $\begin{array}{l}505 \text { Brewington } \\
\text { Avenue }\end{array}$ & 505 Brewington Ave & 1930 \\
\hline $\begin{array}{l}\text { Fred and Ethel } \\
\text { Hudson Residence }\end{array}$ & 518 Brewington Ave & $1935-1940$ \\
\hline Dr. Eiskamp Home & 523 Brewington Ave & 1934 \\
\hline $\begin{array}{l}\text { Earl and Evelyn } \\
\text { Goon Residence }\end{array}$ & 755 California St & 1950 \\
\hline $\begin{array}{l}\text { Judge Lucius } \\
\text { Holbrook Home }\end{array}$ & 231 Center St & 1870 \\
\hline 141 and 143 Elm St & 141 and 143 Elm St & $1870-1890$ \\
\hline 163 Elm St & $163 \mathrm{Elm} \mathrm{St}$ & $1870-1890$ \\
\hline $\begin{array}{l}209 \text { East Fifth } \\
\text { Street }\end{array}$ & 209 E Fifth St & $1890-1910$ \\
\hline J.S. Menasco Home & 14 W Fifth St & 1884 \\
\hline F. Cornell Home & 56 W Fifth St & 1905 \\
\hline 108 Ford Street & 108 Ford St & 1870 's \\
\hline 204 Ford Street & 204 Ford St & $1870-1890$ \\
\hline 35 Gonzales Street & 35 Gonzales St & 1930 \\
\hline $\begin{array}{l}\text { James Ingham } \\
\text { Home }\end{array}$ & 22 E High St & $1870-1890$ \\
\hline Naturipe & 305 Industrial Rd & 1917 \\
\hline $\begin{array}{l}\text { William Weeks } \\
\text { Home }\end{array}$ & 17 Jefferson St & $1895-1900$ \\
\hline Peter Jensen Home & 102 Jefferson St & 1902 \\
\hline 103 Jefferson Street & 103 Jefferson St & 1904 \\
\hline 138 Jefferson Street & 138 Jefferson St & $1910-1930$ \\
\hline Resetar House & 214 E Lake Ave & $1910-1930$ \\
\hline
\end{tabular}




\begin{tabular}{|c|c|c|}
\hline NAME & ADDRESS & YEAR_BUI \\
\hline $\begin{array}{l}262 \text { East Lake } \\
\text { Avenue }\end{array}$ & 262 E Lake Ave & 1870 \\
\hline Tuttle House & 723 E Lake Ave & 1899 \\
\hline $\begin{array}{l}\text { James and Carol } \\
\text { Rodgers Home }\end{array}$ & 2601 E Lake Ave & 1867 \\
\hline 29 Lincoln Street & 29 Lincoln St & 1870 \\
\hline $\begin{array}{l}\text { J.M. Grimmer } \\
\text { Home }\end{array}$ & 301 Lincoln St & $1850-1870$ \\
\hline Blackburn Home & 512 Lincoln St & 1870 \\
\hline Hotel Resetar & 15 W Lake Ave & 1927 \\
\hline Resetar Block & 435 Main St & $1930-1940$ \\
\hline Mundheuk Building & 440 Main St & 1897 \\
\hline $\begin{array}{l}\text { Harris/Jack Novcich } \\
\text { Building }\end{array}$ & 448-450 Main St & 1910 \\
\hline $\begin{array}{l}\text { Holgerson \& } \\
\text { Schmidt Building }\end{array}$ & 531 Main St & 1925 \\
\hline $\begin{array}{l}\text { Phillips Petroleum } \\
\text { Gas Station }\end{array}$ & 570 Main St & $1930-1950$ \\
\hline $\begin{array}{l}\text { Coast Counties Gas } \\
\& \text { Electric }\end{array}$ & 618 Main St & 1932 \\
\hline St. Patrick's Church & 721 Main St & 1903 \\
\hline St. Patrick's Rectory & 721 Main St & 1927 \\
\hline Fox Theater & 15 Maple Ave & 1923 \\
\hline $\begin{array}{l}\text { Mateo Lettunich } \\
\text { Home }\end{array}$ & 110 Maple Ave & 1895 \\
\hline M. Astin Home & 114 Maple Ave & 1892 \\
\hline $\begin{array}{l}\text { William Trafton } \\
\text { Home }\end{array}$ & 144 Maple Ave & 1892 \\
\hline $\begin{array}{l}\text { William Puliovich } \\
\text { Home }\end{array}$ & 148 Maple Ave & 1892 \\
\hline B. Binsacca Home & 151 Maple Ave & 1898 \\
\hline P.H. Sheeny Home & 163 Maple Ave & 1900 \\
\hline $\begin{array}{l}\text { Benjamin Burland } \\
\text { Home }\end{array}$ & 240 Maple Ave & 1900 \\
\hline 52 Marchant & 52 Marchant St & $1850-1870$ \\
\hline 66 Marchant & 66 Marchant St & $1850-1870$ \\
\hline Brassel Home & 200 Marchant St & $1870-1890$ \\
\hline $\begin{array}{l}120 \& 124 \\
\text { Martinelli St }\end{array}$ & $\begin{array}{l}120 \& 124 \\
\text { Martinelli St }\end{array}$ & 1940 \\
\hline Woolpert House & 449 Martinelli St & 1959 \\
\hline Ford Cottage & 214 Palm Ave & $1870-1890$ \\
\hline $\begin{array}{l}\text { Theo Barnhouse } \\
\text { Home }\end{array}$ & 303 Palm Ave & 1893 \\
\hline Rappe House & 323 Palm Ave & 1925 \\
\hline $\begin{array}{l}\text { Suey Hing } \\
\text { Benevolent Society }\end{array}$ & 118 Riverside Dr & 1930 \\
\hline $\begin{array}{l}\text { Watsonville Charter } \\
\text { School of the Arts }\end{array}$ & 550 Rodriguez St & 1917 \\
\hline
\end{tabular}




\begin{tabular}{|c|c|c|}
\hline NAME & ADDRESS & YEAR_BUILT \\
\hline $\begin{array}{l}571,571 \mathrm{~B} \\
\text { Rodriguez St }\end{array}$ & 571 Rodriguez St & 1880 \\
\hline $\begin{array}{l}\text { 114, } 114.5 \text { Second } \\
\text { Street }\end{array}$ & 114 Second St & 1870 \\
\hline 143 Second Street & 143 Second St & 1890 \\
\hline Solari House & 150 Second St & $1890-1910$ \\
\hline $\begin{array}{l}\text { 308-314 Second } \\
\text { Street }\end{array}$ & 308-314 Second St & 1925 \\
\hline 430 Second Street & 430 Second St & $1850-1870$ \\
\hline Blaisdell Home & 405 Stanford St & 1935 \\
\hline McQuiddy Home & 410 Stanford St & 1950 's \\
\hline $\begin{array}{l}\text { John Buckhart } \\
\text { Home }\end{array}$ & 26 Sudden St & 1901 \\
\hline Edward Kelly Home & 50 Sudden St & 1901 \\
\hline 33 Walker Street & 33 Walker St & 1870 \\
\hline $\begin{array}{l}45 \text { White Street- } \\
\text { Ford Cottage }\end{array}$ & 45 White St & 1870 \\
\hline $\begin{array}{l}54 \text { White Street- } \\
\text { Ford Cottage }\end{array}$ & 54 White St & 1870 \\
\hline Roach School & 221 Airport Blvd & 1903 \\
\hline
\end{tabular}


APPENDIX B

DAY CARE FACILITIES 


\section{DayCareFacilities}

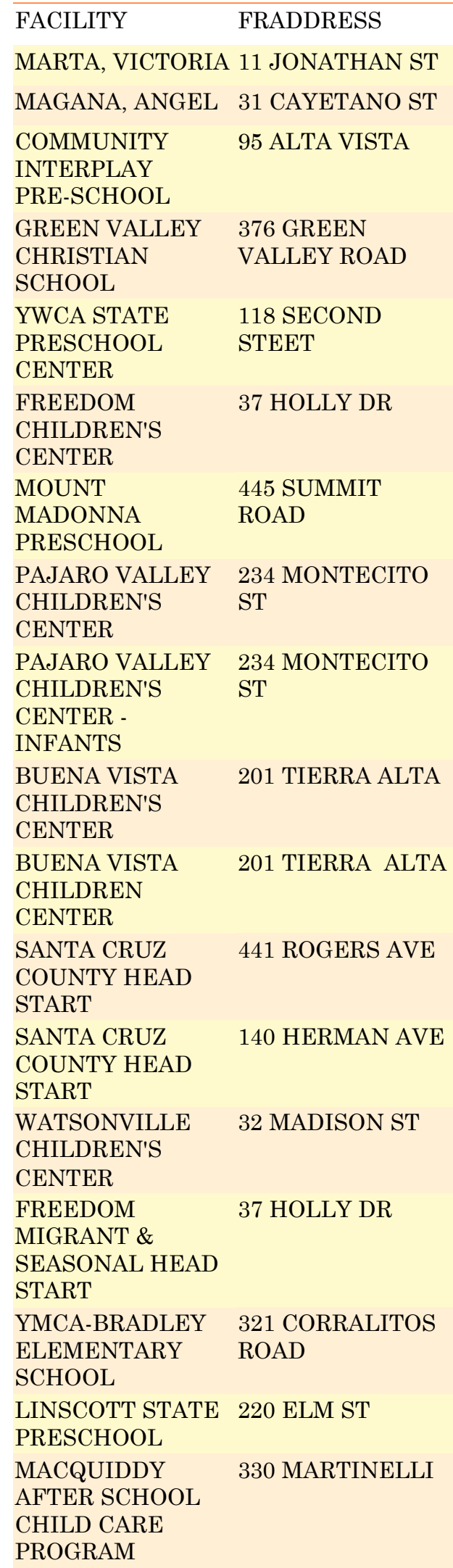




\begin{tabular}{|c|c|}
\hline FACILITY & FRADDRESS \\
\hline $\begin{array}{l}\text { STARLIGHT } \\
\text { PRESCHOOL } \\
\text { CENTER }\end{array}$ & 235 HAMMER DR \\
\hline $\begin{array}{l}\text { TERRY JIMENEZ } \\
\text { CHILDREN'S } \\
\text { CENTER }\end{array}$ & $\begin{array}{l}201 \text { BREWINGTON } \\
\text { AVE }\end{array}$ \\
\hline $\begin{array}{l}\text { CALABASAS } \\
\text { INFANT-TODDLER } \\
\text { MIGRANT HEAD } \\
\text { START }\end{array}$ & $\begin{array}{l}202 \text { CALABASAS } \\
\text { ROAD }\end{array}$ \\
\hline $\begin{array}{l}\text { H.A. HYDE } \\
\text { PRESCHOOL } \\
\text { CENTER }\end{array}$ & $\begin{array}{l}125 \text { ALTA VISTA } \\
\text { AVE. }\end{array}$ \\
\hline $\begin{array}{l}\text { H.A. HYDE } \\
\text { INFANT-TODDLER } \\
\text { MIGRANT HEAD } \\
\text { START }\end{array}$ & $\begin{array}{l}125 \text { ALTA VISTA } \\
\text { AVE. }\end{array}$ \\
\hline $\begin{array}{l}\text { CALABASAS } \\
\text { PRESCHOOL } \\
\text { CENTER }\end{array}$ & $\begin{array}{l}202 \text { CALABASAS } \\
\text { RD. }\end{array}$ \\
\hline $\begin{array}{l}\text { SANTA CRUZ CO. } \\
\text { HEAD START }\end{array}$ & $\begin{array}{l}\text { 340-B EAST } \\
\text { BEACH ST }\end{array}$ \\
\hline MORELOS, MARIA & $\begin{array}{l}326 \text { BUENA VISTA } \\
\text { DR }\end{array}$ \\
\hline $\begin{array}{l}\text { SILVA, MARIA \& } \\
\text { JOAO }\end{array}$ & 64 HOLM ROAD \\
\hline $\begin{array}{l}\text { ARELLANO, } \\
\text { CIPIANA \& DAVID } \\
\text { GOMEZ, ALFONSO }\end{array}$ & $\begin{array}{l}411 \text { WINCHESTER } \\
\text { DR } \\
69 \text { ARTHUR ROAD }\end{array}$ \\
\hline PIRES, MARIA & 14 CRESCENT DR \\
\hline $\begin{array}{l}\text { BETTENCOURT, } \\
\text { NATAL }\end{array}$ & 111 GINOS CT \\
\hline $\begin{array}{l}\text { GOMEZ, CELIA \& } \\
\text { JOSE }\end{array}$ & $\begin{array}{l}213 \text { RIVERSIDE } \\
\text { DR }\end{array}$ \\
\hline PARRA, ANA & 82 ARISTA CT \\
\hline $\begin{array}{l}\text { MARTINEZ, } \\
\text { CATALINA }\end{array}$ & 618 ORCHARD ST \\
\hline SEGURA, MARTHA & 232 MAPLE ST \\
\hline $\begin{array}{l}\text { CASTILLO, } \\
\text { ESTHER }\end{array}$ & 15 MAGNOLIA DR \\
\hline ROCHA, BERTHA & $\begin{array}{l}24 \text { VISTA POINT } \\
\text { DR }\end{array}$ \\
\hline MACHADO, LUCIA & $\begin{array}{l}62 \text { DOERING } \\
\text { LANE }\end{array}$ \\
\hline JIMENEZ, ELPIE & $\begin{array}{l}516 \text { BLACKBURN } \\
\text { ST }\end{array}$ \\
\hline GARCIA, ANNA & $\begin{array}{l}214 \text { BOWKER } \\
\text { ROAD }\end{array}$ \\
\hline $\begin{array}{l}\text { BETTENCOURT, } \\
\text { MARIA }\end{array}$ & $\begin{array}{l}\text { 134 WILLIAM } \\
\text { AVANUE }\end{array}$ \\
\hline NOVELO, GLORIA & 209 KIRSTEN CT \\
\hline FELIX, MARIA & 211 SUDDEN ST \\
\hline AYALA, JUANITA & 566 IRIS DR \\
\hline
\end{tabular}




\begin{tabular}{|c|c|}
\hline FACILITY & FRADDRESS \\
\hline \multicolumn{2}{|l|}{ \& ALEJANDRO } \\
\hline GOMEZ, MARIA \& & 135 WILLOW \\
\hline TAURINO & CREEK ST \\
\hline $\begin{array}{l}\text { PAREDEZ, } \\
\text { THERESA }\end{array}$ & 217 MILES LANE \\
\hline \multicolumn{2}{|c|}{ DIAZ, HORTENCIA 320 ARBOL DR } \\
\hline $\begin{array}{l}\text { SABATINO, } \\
\text { DONNA }\end{array}$ & 505 ALAGA LANE \\
\hline $\begin{array}{l}\text { HERNANDEZ, } \\
\text { GUADALUPE }\end{array}$ & 748 HILL AVE \\
\hline $\begin{array}{l}\text { GALLO, } \\
\text { ELEODORA }\end{array}$ & 14 NONA AVE \\
\hline PERRY, CINDY & 329 HAMES ROAD \\
\hline $\begin{array}{l}\text { GUTIERREZ, } \\
\text { MARIA }\end{array}$ & 22 ALTAMONT DR \\
\hline $\begin{array}{l}\text { NOVELO, } \\
\text { BEATRICE }\end{array}$ & $\begin{array}{l}321 \text { BRIARWOOD } \\
\text { DR }\end{array}$ \\
\hline $\begin{array}{l}\text { JACINTO, } \\
\text { RAMONA \& } \\
\text { FRANK }\end{array}$ & 127 HERMAN AVE \\
\hline $\begin{array}{l}\text { RENTERIA, } \\
\text { CRISTINA }\end{array}$ & $\begin{array}{l}33 \text { SAN TOMAS } \\
\text { WAY }\end{array}$ \\
\hline $\begin{array}{l}\text { SANCHEZ, } \\
\text { LOURDES }\end{array}$ & 617 OREGON ST \\
\hline $\begin{array}{l}\text { ROCHA, BERTHA } \\
\text { \& DAVID }\end{array}$ & $\begin{array}{l}125 \text { ARTHUR } \\
\text { ROAD }\end{array}$ \\
\hline $\begin{array}{l}\text { NOLASCO, } \\
\text { LUCINA \& ISAIAS }\end{array}$ & $\begin{array}{l}145 \text { MARTINELLI } \\
\text { ST }\end{array}$ \\
\hline RUIZ, ELVIRA & $\begin{array}{l}90 \text { LAWRENCE } \\
\text { AVE }\end{array}$ \\
\hline $\begin{array}{l}\text { OSORNIO, } \\
\text { LETICIA }\end{array}$ & $\begin{array}{l}19 \text { BURCHELL } \\
\text { AVE }\end{array}$ \\
\hline $\begin{array}{l}\text { ZAMUDIO, } \\
\text { VELINA }\end{array}$ & 49 KILBURN ST \\
\hline SALGADO, ELIDIA & $\begin{array}{l}\text { 311 ARTHUR } \\
\text { ROAD }\end{array}$ \\
\hline HERNANDEZ, EVA & $\begin{array}{l}403 \text { SANTA CLARA } \\
\text { ST }\end{array}$ \\
\hline $\begin{array}{l}\text { SANDOVAL, } \\
\text { VERONICA \& } \\
\text { FLORES, } \\
\text { ANGELICA }\end{array}$ & 709 GLEMAR ST \\
\hline $\begin{array}{l}\text { FERNANDEZ, } \\
\text { MARIA }\end{array}$ & $\begin{array}{l}176 \text { LAWRENCE } \\
\text { AVE }\end{array}$ \\
\hline $\begin{array}{l}\text { MENA, ADELICIA } \\
\& \text { ROGELIO }\end{array}$ & $\begin{array}{l}435 \text { CALIFORNIA } \\
\text { ST }\end{array}$ \\
\hline $\begin{array}{l}\text { GALLEGOS, } \\
\text { TERESA }\end{array}$ & 924-B LINCOLN ST \\
\hline TORRES, MARIA & 440 SECOND ST \\
\hline $\begin{array}{l}\text { MAGDALENO, } \\
\text { ESPERANZA }\end{array}$ & $\begin{array}{l}828 \text { GREEN } \\
\text { VALLEY ROAD }\end{array}$ \\
\hline LOPEZ, MARIA & $\begin{array}{l}\text { 634 MARTINELLI } \\
\text { ST }\end{array}$ \\
\hline ARELLANO, & 311 MARCHANT \\
\hline
\end{tabular}




\begin{tabular}{|c|c|}
\hline FACILITY & FRADDRESS \\
\hline MARIA & ST \\
\hline ZAMORA, HILDA & 128 KEARNEY ST \\
\hline MORALES, MARIA & 154 LOGAN ST \\
\hline $\begin{array}{l}\text { ARELLANO, JUNE } \\
\text { \& ALEX }\end{array}$ & 108 DOGWOOD DR \\
\hline AMEZCUA, MARIA & $\begin{array}{l}146 \text { WEST FIFTH } \\
\text { ST }\end{array}$ \\
\hline $\begin{array}{l}\text { DA SILVA, } \\
\text { MARTHA }\end{array}$ & $\begin{array}{l}200 \text { MARCHANT } \\
\text { ST }\end{array}$ \\
\hline $\begin{array}{l}\text { CASILLAS, } \\
\text { GRACIELA }\end{array}$ & $\begin{array}{l}196 \text { DUTCHMAN } \\
\text { ROAD }\end{array}$ \\
\hline $\begin{array}{l}\text { ANDRADE, MARIA } \\
\& \text { JOSE LUIS }\end{array}$ & 56 PEACE DR \\
\hline $\begin{array}{l}\text { DIAZ-SANCHEZ, } \\
\text { LETICIA }\end{array}$ & 101 SOUTH DR \\
\hline $\begin{array}{l}\text { RODRIGUEZ, } \\
\text { ANNA }\end{array}$ & 445 WAGNER AVE \\
\hline $\begin{array}{l}\text { GONZALEZ, } \\
\text { ELIZABETH }\end{array}$ & $\begin{array}{l}525 \text { CALIFORNIA } \\
\text { ST }\end{array}$ \\
\hline ALVAREZ, MARIA & 138 SAN SIMEON \\
\hline $\begin{array}{l}\text { GOMEZ, EVA \& } \\
\text { MURILLO, JUAN }\end{array}$ & $\begin{array}{l}66 \text { LOMA PRIETA } \\
\text { AVE }\end{array}$ \\
\hline $\begin{array}{l}\text { FERNANDEZ, } \\
\text { ROSALIA }\end{array}$ & 443 ROGGE ST \\
\hline ROCHA, LETICIA & $\begin{array}{l}66 \text { LAWERENCE } \\
\text { AVE }\end{array}$ \\
\hline PEREZ, SOLEDAD & $\begin{array}{l}49 \text { BLANCA LANE } \\
\# 82\end{array}$ \\
\hline $\begin{array}{l}\text { MONTESINOS, } \\
\text { RAQUEL \& } \\
\text { GARCIA, RAMIRO }\end{array}$ & $\begin{array}{l}180 \text { CARNATION } \\
\text { DR }\end{array}$ \\
\hline ROCHA, IRMA & $\begin{array}{l}612 \text { GREEN } \\
\text { VALLEY ROAD }\end{array}$ \\
\hline $\begin{array}{l}\text { RAMIREZ, } \\
\text { BENIGNA }\end{array}$ & $\begin{array}{l}217 \text { KIMBERLY } \\
\text { LANE }\end{array}$ \\
\hline $\begin{array}{l}\text { ROCHA, AURORA } \\
\& \text { ANAYA, } \\
\text { ARNULFO }\end{array}$ & $\begin{array}{l}30 \text { LITTLEWAY } \\
\text { LANE }\end{array}$ \\
\hline BARBA, LOURDES & $\begin{array}{l}339 \text { ARTHUR } \\
\text { ROAD }\end{array}$ \\
\hline $\begin{array}{l}\text { MORALES, } \\
\text { LOURDES }\end{array}$ & 47 ROOSEVELT ST \\
\hline $\begin{array}{l}\text { SORIANO, } \\
\text { PATRICIA }\end{array}$ & $\begin{array}{l}504 \text { WINCHESTER } \\
\text { ROAD }\end{array}$ \\
\hline $\begin{array}{l}\text { FERNANDEZ, } \\
\text { MARIA }\end{array}$ & 238 JOLON DR \\
\hline $\begin{array}{l}\text { HUANTE, } \\
\text { BEATRICE \& NOE }\end{array}$ & 11 MAGNOLIA DR \\
\hline LOBATO, TERESA & 120 PONDEROSA \\
\hline $\begin{array}{l}\text { ORTEGA, } \\
\text { ESPERANZA }\end{array}$ & $\begin{array}{l}25-\mathrm{E} \\
\text { HOLLOWVIEW } \\
\text { LANE }\end{array}$ \\
\hline $\begin{array}{l}\text { MARTINEZ, } \\
\text { LEONOR \& }\end{array}$ & $\begin{array}{l}105 \text { RAINBOW } \\
\text { LANE }\end{array}$ \\
\hline
\end{tabular}




\begin{tabular}{|c|c|}
\hline FACILITY & FRADDRESS \\
\hline \multicolumn{2}{|l|}{ MEDINA, LUIS } \\
\hline $\begin{array}{l}\text { HERNANDEZ, } \\
\text { LISA \& JOSE }\end{array}$ & 187 WILLIAM AVE \\
\hline $\begin{array}{l}\text { CASTILLO, } \\
\text { GUADALUPE \& } \\
\text { MARITZA }\end{array}$ & 149 SANTA CLARA \\
\hline ESPINOZA, MARIA & $\begin{array}{l}32 \text { VISTA POINTE } \\
\text { DR }\end{array}$ \\
\hline CAMARGO, MARIA & $\begin{array}{l}217 \text { RIVERSIDE } \\
\text { DR }\end{array}$ \\
\hline $\begin{array}{l}\text { JIMENEZ, } \\
\text { ROSALIA }\end{array}$ & 10 EILEEN ST \\
\hline $\begin{array}{l}\text { BIDDLECOME, } \\
\text { SYLVIA }\end{array}$ & $\begin{array}{l}112 \text { SAN TOMAS } \\
\text { WAY }\end{array}$ \\
\hline VARGAS, MARIA & 127 GRANT ST \\
\hline $\begin{array}{l}\text { VALENCIA, } \\
\text { GRISELDA }\end{array}$ & 152 NAPA ST \\
\hline $\begin{array}{l}\text { VISTA VERDE } \\
\text { CHILD } \\
\text { DEVELOPMENT } \\
\text { CENTER }\end{array}$ & $\begin{array}{l}1936 \text { FREEDOM } \\
\text { BLVD. }\end{array}$ \\
\hline $\begin{array}{l}\text { SANTA CRUZ } \\
\text { COUNTY HEAD } \\
\text { START }\end{array}$ & $\begin{array}{l}\text { 1936-A FREEDOM } \\
\text { BOULEVARD }\end{array}$ \\
\hline $\begin{array}{l}\text { PALMERIN, } \\
\text { ESTELA }\end{array}$ & 633 LINCOLN \\
\hline HURLEY, DEBBIE & 633 PALM AVE \\
\hline $\begin{array}{l}\text { HEART AND } \\
\text { HANDS } \\
\text { CHRISTIAN } \\
\text { CHILDCARE \& } \\
\text { PRESCHOOL }\end{array}$ & 40 BLANCA LANE \\
\hline ZAMORA, JOVITA & $\begin{array}{l}\text { 145 MANANA } \\
\text { LANE }\end{array}$ \\
\hline $\begin{array}{l}\text { STRICKER, } \\
\text { AURORA }\end{array}$ & 825 CALIFORNIA \\
\hline NUNEZ, YOLANDA & 351 ARBOL DR \\
\hline $\begin{array}{l}\text { CASTORENA, } \\
\text { SUEMY }\end{array}$ & $\begin{array}{l}263 \text { BOWKER } \\
\text { ROAD }\end{array}$ \\
\hline VARGAS, MARIA & 422 MADISON ST \\
\hline SALGADO, EMILIA & 50 MAGNOLIA DR \\
\hline QUINTERO, ROSIE & 214 EAST HIGH ST \\
\hline $\begin{array}{l}\text { NOLASCO } \\
\text { FERNANDEZ, } \\
\text { MAURILIA }\end{array}$ & $\begin{array}{l}18 \text { RICHARDSON } \\
\text { AVE }\end{array}$ \\
\hline ROSAS, MARIA & $\begin{array}{l}240 \text { MISTY GLADE } \\
\text { LANE \#E }\end{array}$ \\
\hline GARCIA, PERLA & 610 OREGON ST \\
\hline $\begin{array}{l}\text { FERNANDEZ, } \\
\text { YOLANDA }\end{array}$ & $\begin{array}{l}13 \text { KINGFISHER } \\
\text { DR }\end{array}$ \\
\hline LOBATO, MARIA & $\begin{array}{l}16 \text { PAULSEN } \\
\text { ROAD }\end{array}$ \\
\hline ROMERO, MARIA & 6 VIA VENTANA \\
\hline
\end{tabular}




\begin{tabular}{|c|c|}
\hline FACILITY & FRADDRESS \\
\hline & $\mathrm{CT}$ \\
\hline $\begin{array}{l}\text { ELLIOTT, } \\
\text { COLEEN }\end{array}$ & $\begin{array}{l}1287 \text { AMESTI } \\
\text { ROAD }\end{array}$ \\
\hline $\begin{array}{l}\text { NOLASCO, } \\
\text { LETICIA }\end{array}$ & 18 LA JOLLA ST \\
\hline GIL, IMELDA & $\begin{array}{l}264 \text { BARBARA } \\
\text { WAY }\end{array}$ \\
\hline $\begin{array}{l}\text { VASQUEZ, } \\
\text { TERESA }\end{array}$ & 593 CREEK DR \\
\hline $\begin{array}{l}\text { GRANADOS, ANA } \\
\text { MARIA }\end{array}$ & 7 VIA SERRA \\
\hline $\begin{array}{l}\text { CHAVEZ, CELINA } \\
\text { \& ORTIZ, YESICA }\end{array}$ & 226 SUDDEN ST \\
\hline $\begin{array}{l}\text { ZEPEDA, } \\
\text { MARIBEL }\end{array}$ & 151 ONYX DR \\
\hline $\begin{array}{l}\text { BOBEDA, } \\
\text { CATHERINE }\end{array}$ & 18 ALLSTON WAY \\
\hline DIAZ, VERONICA & 150 WILLIAM AVE \\
\hline $\begin{array}{l}\text { ESCOBAR, LUZ } \\
\text { MARIA }\end{array}$ & $\begin{array}{l}78 \text { SAN TOMAS } \\
\text { WAY }\end{array}$ \\
\hline $\begin{array}{l}\text { MELGOZA, } \\
\text { GLORIA }\end{array}$ & $\begin{array}{l}37 \text { ORANGE } \\
\text { BLOSSOM WAY }\end{array}$ \\
\hline BALTAZAR, LUISA & $\begin{array}{l}13 \text { SHADY OAKS } \\
\text { DR }\end{array}$ \\
\hline JIMENEZ, MAURA & 40 TRABING ROAD \\
\hline SANCHEZ, HILDA & $\begin{array}{l}936 \text { MCKENZIE } \\
\text { AVE }\end{array}$ \\
\hline ZAMORA, ROSA & $\begin{array}{l}789 \text { GREEN } \\
\text { VALLEY ROAD \#65 }\end{array}$ \\
\hline $\begin{array}{l}\text { MELGOZA, } \\
\text { LOURDES }\end{array}$ & $\begin{array}{l}49 \text { BLANCA LANE } \\
\# 89\end{array}$ \\
\hline SANCHEZ, MARIA & 49 HOLM ROAD \\
\hline MAGANA, ROSA & 7 PIMA ST \\
\hline $\begin{array}{l}\text { FERNANDEZ, } \\
\text { ESTHER }\end{array}$ & 336 ARBOL DR \\
\hline $\begin{array}{l}\text { HARRIS, } \\
\text { PATIENCE }\end{array}$ & 1037 SUNBIRD DR \\
\hline FLORES, MARIA & 35 KILBURN ST \\
\hline REYNOSO, MARIA & 103 CRISSARA DR \\
\hline PEREZ, SANDRA & 571 JOYCE CT \\
\hline ROCHA, MARIA & 529 CEREZE ST \\
\hline LEAL, MARIA & $\begin{array}{l}605 \text { MARTINELLI } \\
\text { ST }\end{array}$ \\
\hline PEREDIA, MARIA & 27 MELWOOD CT \\
\hline TITAL, DONNA & 20 MONTE VISTA \\
\hline $\begin{array}{l}\text { MENDOZA, } \\
\text { CRISANTA }\end{array}$ & $\begin{array}{l}34 \text { SHADY OAKS } \\
\text { DR }\end{array}$ \\
\hline $\begin{array}{l}\text { VALENCIA, } \\
\text { ESPERANZA }\end{array}$ & 193 HAMMER DR \\
\hline $\begin{array}{l}\text { HERNANDEZ- } \\
\text { FERNANDEZ, }\end{array}$ & 140 NAPA ST \\
\hline
\end{tabular}




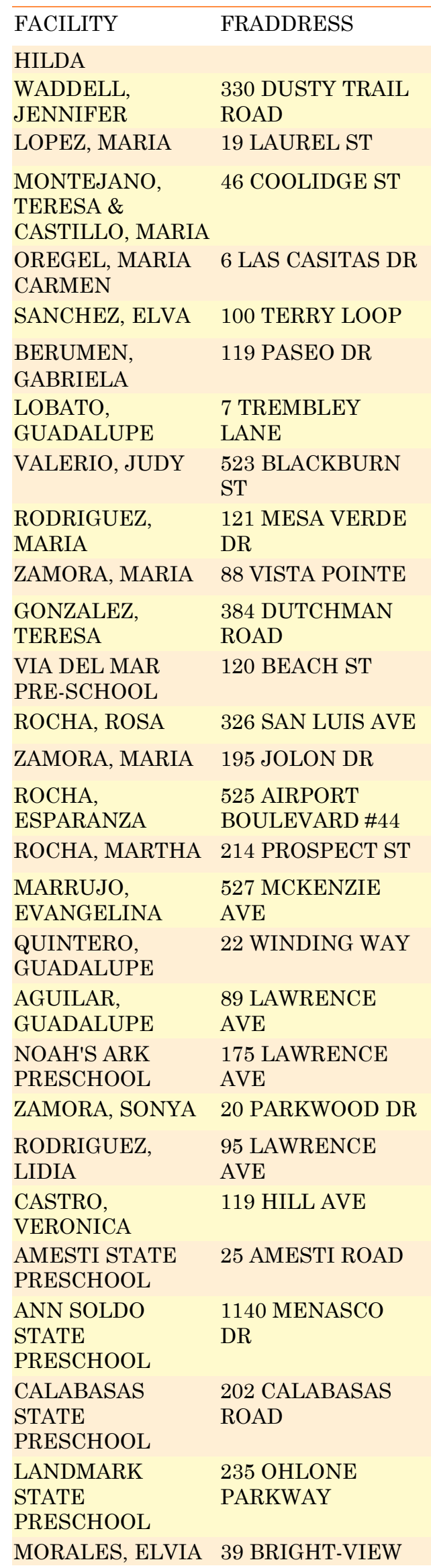




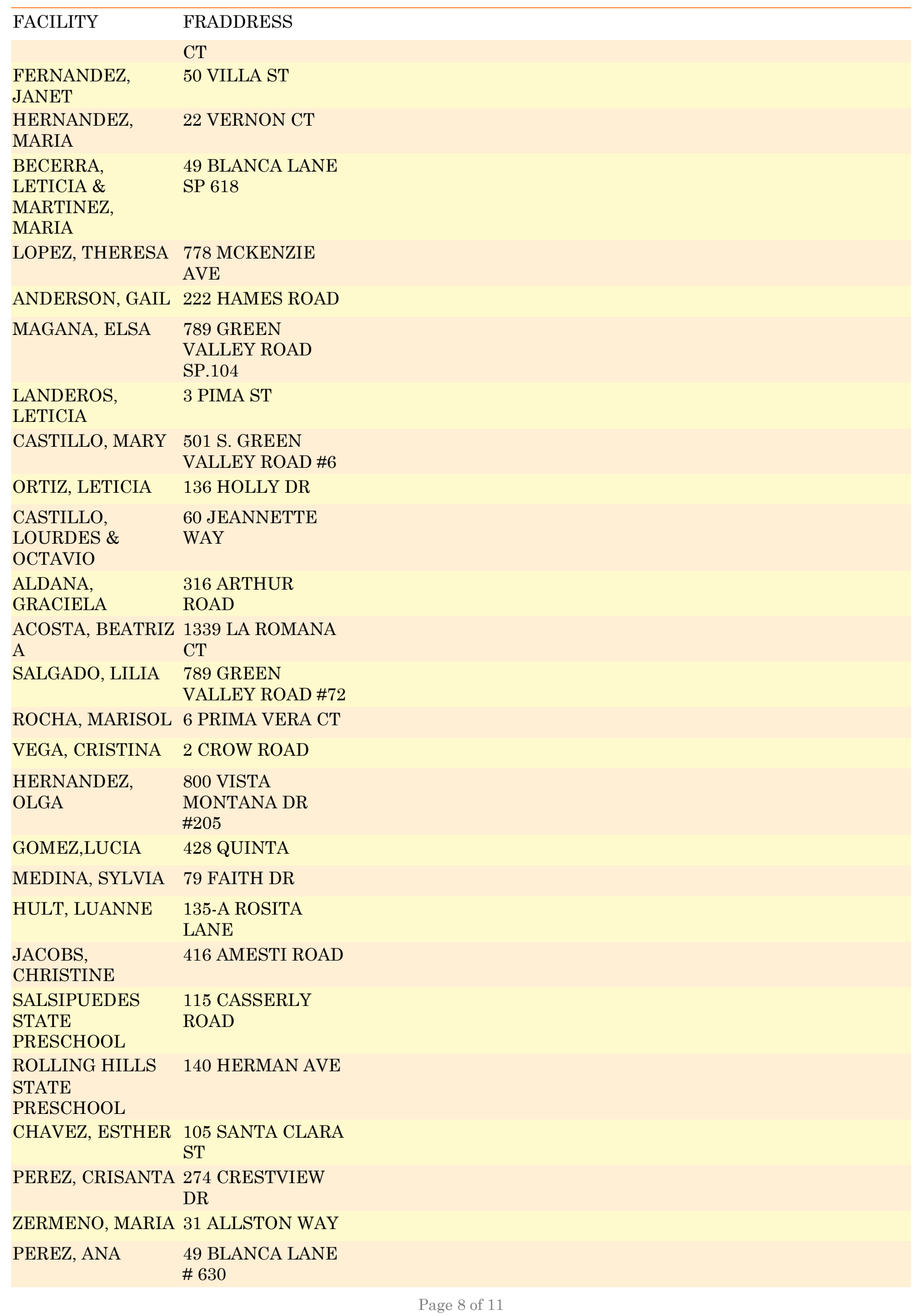




\begin{tabular}{|c|c|}
\hline FACILITY & FRADDRESS \\
\hline MENESES, MARIA & 112 KELLY CT \\
\hline TORRES, NORMA & $\begin{array}{l}17 \text { BRADFORD } \\
\text { ROAD }\end{array}$ \\
\hline CAMARENA, ROSE & 443 BARON CT \\
\hline PEREZ, MARTHA & $\begin{array}{l}425 \text { MARTINELLI } \\
\text { ST }\end{array}$ \\
\hline CASTILLO, SILVIA & 29 COOLIDGE AVE \\
\hline $\begin{array}{l}\text { FERNANDEZ, } \\
\text { MARIA }\end{array}$ & 25 ARTHUR ROAD \\
\hline $\begin{array}{l}\text { MALDONADO, } \\
\text { OFELIA }\end{array}$ & 1213 LINCOLN ST \\
\hline $\begin{array}{l}\text { PANZICH, } \\
\text { ELIZABETH }\end{array}$ & $\begin{array}{l}225 \text { PIONEER } \\
\text { VIEW ROAD }\end{array}$ \\
\hline RAMOS, ELVIRA & $\begin{array}{l}\text { 261-C CLIFFORD } \\
\text { AVE }\end{array}$ \\
\hline QUIROZ, LUZ & $\begin{array}{l}22 \text { LOWER } \\
\text { CUTTER DR }\end{array}$ \\
\hline $\begin{array}{l}\text { SALGADO, } \\
\text { OFELIA }\end{array}$ & $\begin{array}{l}81 \text { VISTA POINTE } \\
\text { DR }\end{array}$ \\
\hline $\begin{array}{l}\text { VILLALOBOS, } \\
\text { OFELIA }\end{array}$ & 575 JOYCE CT \\
\hline SANCHEZ, MARIA & $\begin{array}{l}108 \text { ATKINSON } \\
\text { LANE }\end{array}$ \\
\hline JUAREZ, FAVIOLA & $\begin{array}{l}10 \text { RICHARDSON } \\
\text { AVE }\end{array}$ \\
\hline $\begin{array}{l}\text { ANDERSON, } \\
\text { HANA }\end{array}$ & 180 HALEY LANE \\
\hline $\begin{array}{l}\text { CASTILLO, } \\
\text { MARGARITA }\end{array}$ & 722 ARCE ST \\
\hline $\begin{array}{l}\text { FAIRGROUNDS } \\
\text { CHILD } \\
\text { DEVELOPMENT } \\
\text { CENTER } \\
\text { PARTIDA, GLORIA }\end{array}$ & $\begin{array}{l}2667 \text { EAST LAKE } \\
\text { AVE }\end{array}$ \\
\hline $\begin{array}{l}\text { BRADLEY STATE } \\
\text { PRESCHOOL }\end{array}$ & $\begin{array}{l}321 \text { CORRALITOS } \\
\text { ROAD }\end{array}$ \\
\hline ROCHA, ALICIA & $\begin{array}{l}105 \text { SUNNYHILLS } \\
\text { DR }\end{array}$ \\
\hline $\begin{array}{l}\text { FERNANDEZ, } \\
\text { MARIA }\end{array}$ & $\begin{array}{l}525 \text { AIRPORT } \\
\text { BLVD. SP39 }\end{array}$ \\
\hline $\begin{array}{l}\text { HERRERA, } \\
\text { FLORENCIA }\end{array}$ & 1O MOHOVE ST \\
\hline $\begin{array}{l}\text { PANIAGUA, } \\
\text { PATRICIA }\end{array}$ & 20 DEVON LANE \\
\hline MENA, MONICA & 33 PEACE CT \\
\hline $\begin{array}{l}\text { CARRILLO, } \\
\text { CATALINA }\end{array}$ & $\begin{array}{l}34 \text { HOLOHAN } \\
\text { ROAD }\end{array}$ \\
\hline $\begin{array}{l}\text { JENNINGS, } \\
\text { SARAH }\end{array}$ & 101 PELICAN DR \\
\hline RUBIO, AMY & 1245 EL MAR CT \\
\hline LEON, LUCILA & $\begin{array}{l}275 \text { CASSERLY } \\
\text { ROAD }\end{array}$ \\
\hline RODRIGUEZ, LUZ & 62 HOLLY DR \\
\hline
\end{tabular}




\begin{tabular}{|c|c|}
\hline FACILITY & FRADDRESS \\
\hline $\begin{array}{l}\text { GONZALEZ, } \\
\text { IRENE }\end{array}$ & 125 NORTH DR \\
\hline $\begin{array}{l}\text { PORTER VALLEJO } \\
\text { CHILD } \\
\text { DEVELOPMENT } \\
\text { CENTER }\end{array}$ & 29 BISHOP ROAD \\
\hline $\begin{array}{l}\text { OHLONE } \\
\text { PRESCHOOL } \\
\text { MIGRANT HEAD } \\
\text { START }\end{array}$ & $\begin{array}{l}21 \text { BAY FARMS } \\
\text { RD. }\end{array}$ \\
\hline $\begin{array}{l}\text { OHLONE } \\
\text { INFANT-TODDLER } \\
\text { MIGRANT HEAD } \\
\text { START }\end{array}$ & $\begin{array}{l}21 \text { BAY FARMS } \\
\text { ROAD }\end{array}$ \\
\hline $\begin{array}{l}\text { HENDERSON, } \\
\text { MARY }\end{array}$ & 40 MEADOW WAY \\
\hline VIDAL, MARIA & $\begin{array}{l}41 \text { OVERPASS } \\
\text { ROAD }\end{array}$ \\
\hline $\begin{array}{l}\text { PANIAGUA, } \\
\text { MARIA }\end{array}$ & 54 MILLER ROAD \\
\hline ROCHA, MARIA & $\begin{array}{l}54 \text { OVERPASS } \\
\text { ROAD }\end{array}$ \\
\hline $\begin{array}{l}\text { ALVAREZ, MARIA } \\
\text { TERESA }\end{array}$ & $\begin{array}{l}135 \text { LAS LOMAS } \\
\text { DR }\end{array}$ \\
\hline $\begin{array}{l}\text { ROCHA, } \\
\text { JOSEFINA }\end{array}$ & 104 B HALL ROAD \\
\hline $\begin{array}{l}\text { HALL DISTRICT } \\
\text { MIGRANT \& } \\
\text { SEASONAL HEAD } \\
\text { START }\end{array}$ & 300 SILL ROAD \\
\hline $\begin{array}{l}\text { FERNANDEZ, } \\
\text { MARIA }\end{array}$ & 374 BERRY ROAD \\
\hline $\begin{array}{l}\text { VALDEZ, } \\
\text { LOURDES }\end{array}$ & 10 ELSA ST A \\
\hline $\begin{array}{l}\text { SANCHEZ, HILDA } \\
\mathrm{T}\end{array}$ & $\begin{array}{l}263 \text { HUDSON } \\
\text { LANDING ROAD }\end{array}$ \\
\hline RAMIREZ, OLGA & $\begin{array}{l}19 \text { GREGORY } \\
\text { ROAD }\end{array}$ \\
\hline LOPEZ, SILVIA & 29 SALINAS ROAD \\
\hline $\begin{array}{l}\text { HALL HEAD } \\
\text { START }\end{array}$ & $\begin{array}{l}300 \text { SILL ROAD } \\
\text { ROOMS A\&B }\end{array}$ \\
\hline VARGAS, MARIA & $\begin{array}{l}180 \text { HUDSON } \\
\text { LANDING ROAD }\end{array}$ \\
\hline $\begin{array}{l}\text { MENDOZA, } \\
\text { FELICITAS }\end{array}$ & 25 FLORENCE ST \\
\hline AYALA, TERESA & 83 BOLING ROAD \\
\hline ORTIZ, ROCIO & 60 OAK ROAD \\
\hline $\begin{array}{l}\text { MARTINEZ, } \\
\text { MARIA }\end{array}$ & $\begin{array}{l}\text { 43-C LAS LOMAS } \\
\text { DR }\end{array}$ \\
\hline AYALA, OLGA & $\begin{array}{l}129 \text { LAS LOMAS } \\
\text { DR }\end{array}$ \\
\hline $\begin{array}{l}\text { GUTIERREZ, } \\
\text { BLANCA }\end{array}$ & $\begin{array}{l}72 \text { OVERPASS } \\
\text { ROAD }\end{array}$ \\
\hline ZAMORA, & 41 LAS LOMAS \\
\hline
\end{tabular}

\section{Page 10 of 11}




\begin{tabular}{ll}
\hline FACILITY & FRADDRESS \\
ESPERANZA & ROAD \\
HALL DISTRICT & 300 SILL ROAD \\
STATE & \\
PRESCHOOL & \\
DIAZ, RAQUEL & 399 BERRY ROAD \\
HALL DISTRICT & 300 SILL ROAD \\
MIGRANT AND & \\
SEASONAL HEAD & \\
START & \\
FERNANDEZ, & 183 LAS LOMAS \\
MARIA & DR \\
MONTANEZ, & $120-$ B HALL ROAD \\
CLOTILDE & \\
EPRANIAN, & 112 DUNBARTON \\
BRANDY & ROAD \\
VALDEZ, DEXY & 29 FLORENCE \\
& AVE \\
RAMOS, MARIA & 87 CLAUSEN \\
& ROAD \\
FERNANDEZ, & 85 SILL ROAD \\
BLANCA & \\
NAVARRO,NORMA 61 TREMBLEY & LANE
\end{tabular}


APPENDIX C

CRITICAL FACILITIES AND HAZARDS 
Emergency Operations Facilities

\begin{tabular}{|c|c|c|c|c|c|}
\hline Description/ Name of Facility & Address & Flood & Liquefaction & URM & Center \\
\hline $\begin{array}{l}\text { Civic Center (Includes EOP } \\
\text { Center) }\end{array}$ & 275 Main St & $\begin{array}{l}\text { 1\% Annual, 1-3 } \\
\text { Feet Depth }\end{array}$ & & & Restar Residential Hotel \\
\hline Airport & 100 Aviation Way & & & & Wall Street Inn \\
\hline $\begin{array}{l}\text { Police Headquarters } \\
\text { (Communication Center) }\end{array}$ & 215 Union St & $\begin{array}{l}1 \% \text { Annual, 1-3 } \\
\text { Feet Depth }\end{array}$ & High & & Plaza Hotel \\
\hline Fire Station 1 & 115 Second St & $\begin{array}{l}\text { 1\% Annual, 1-3 } \\
\text { Feet Depth }\end{array}$ & High & Yes & Stag Hotel \\
\hline $\begin{array}{l}\text { Fire Station } 2 \text { (Communication } \\
\text { Center) }\end{array}$ & 370 Airport Blvd & & & & Women’s Shelter \\
\hline City Hall & 250 Main St & $\begin{array}{l}\text { 1\% Annual, 1-3 } \\
\text { Feet Depth }\end{array}$ & High & & Salvation Army \\
\hline $\begin{array}{l}\text { Watsonville Community } \\
\text { Hospital }\end{array}$ & 75 Nielson St & & & & $\begin{array}{l}\text { Valley Convalescent } \\
\text { Hospital }\end{array}$ \\
\hline Red Cross Facilities & & & & & $\begin{array}{l}\text { Watsonville Nursing and } \\
\text { Rehabilitation Center }\end{array}$ \\
\hline Watsonville High School & 250 East Beach St & & High & & Sunbridge Care Center \\
\hline Cesar Chavez Middle School & 440 Arthur Rd & & & & Paloma House \\
\hline Rolling Hills Middle School & 130 Herman Rd & & & & Rillera’s Guest Home \\
\hline Bradley Elementary School & 321 Corralitos Rd & & High & & Valley Haven Care Home \\
\hline Lakeview Middle School & 2350 East Lake Ave & & & & Valley Haven Care Home II \\
\hline Ohlone School & 21 Bay Farms Rd & & & & Watsonville Manor \\
\hline Pajaro Middle School & 250 Salinas Rd & & & & $\begin{array}{l}\text { Independence Square } \\
\text { Apartments }\end{array}$ \\
\hline Santa Cruz County Fairgrounds & 2601 East Lake Ave & & & & Pajaro Vista \\
\hline Corralitos Community Free Chur & 26 Browns Valley Rd & & & & Paloma Del Mar \\
\hline Corralitos Grange & 165 Little Corral Way & & & & \\
\hline Holy Eucharist Catholic Church & 527 Corralitos Rd & & High & & \\
\hline Watsonville/Aptos Adult Educati & 280 Main St & & High & & \\
\hline Pajaro Valley High School & 500 Harkins Slough Rd & & & & \\
\hline Salesian Sister School & 605 Enos Ln & & & & \\
\hline Our Lady Help of Christians & 2401 East Lake Ave & & & & \\
\hline
\end{tabular}

Population Centers

\begin{tabular}{|c|c|c|c|}
\hline Location & Flood & Liquefaction & URM \\
\hline 15 West Lake Ave & & High & \\
\hline 30 West Beach St & 2\% Annual & High & \\
\hline 825 Walker St & & High & \\
\hline 117 West Beach St & $2 \%$ Annual & High & \\
\hline 115 Brennon & & High & \\
\hline 112 Grant Ave & $\begin{array}{l}1 \% \text { Annual, } 1 \\
3 \text { Feet Depth }\end{array}$ & High & \\
\hline 919 Freedom Blvd & & & \\
\hline 525 Auto Center Dr & & & \\
\hline 535 Auto Center Dr & & & \\
\hline 321 Beach St & & High & \\
\hline 40 Fletcher Ct & & & \\
\hline 157 Herman Ave & & & \\
\hline 99 Airport Blvd & & & \\
\hline 311 Montecito & & & \\
\hline 1355 Madison & & & \\
\hline 1955 Pajaro & & & \\
\hline 2030 Pajaro & & & \\
\hline
\end{tabular}




\section{Schools}

\begin{tabular}{|l|l|l|l|l|}
\hline Facility & Address & Flood & Liquefaction & URM \\
\hline E. A. Hall Middle School & 201 Brewington Road & & & \\
\hline Watsonville High School & 250 East Beach St & & & \\
\hline Hyde Elementary School & 125 Alta Vista Ave & & & \\
\hline Starlight Elementary School & 225 Hammer Dr & & & \\
\hline Cesar Chavez Middle School & 440 Arthur Dr & & & \\
\hline Rolling Hills Middle School & 130 Herman Rd & & & \\
\hline Freedom Elementary School & 25 Holly Dr & & & \\
\hline Mintie White School & 515 Palm Ave & & High & \\
\hline MacQuidy School & 330 Martinelli St & & High & \\
\hline Ann Soldo School & 1140 Menasco Dr & & High & \\
\hline Green Valley Christian School & $\begin{array}{l}376 \text { South Green Valley } \\
\text { Rd }\end{array}$ & & & \\
\hline Notre Dame Private School & 656 Main St & & High & \\
\hline Calabasas Elementary School * & 202 Calabasas Rd & & & \\
\hline Amesti Elementary School * & 25 Amesti Rd & & High & \\
\hline Linscott Charter School & 220 Elm St & $\begin{array}{l}1 \% \text { Annual, 1-3 } \\
\text { Feet Depth }\end{array}$ & High & \\
\hline Pajaro Valley High School & 500 Harkins Slough Rd & & & \\
\hline Landmark Elementary School & 235 Ohlone Parkway & & & \\
\hline Radcliff Elementary School & 550 Rodriguez St & & High & \\
\hline Watsonville High School & 250 East Beach St & $2 \%$ Annual & High & \\
\hline Pacific Coast Charter & 294 Green Valley Rd & & Very High & \\
\hline AVCI & 112 Diamond Dr & & & \\
\hline Cabrillo College & 310 Union St & $\begin{array}{l}1 \% \text { Annual, 1-3 } \\
\text { Feet Depth }\end{array}$ & High & \\
\hline Pajaro Valley Community Day \\
School & 165 Harkins Slough Rd & & & \\
\hline Duncan Holbert School & 140 Herman Ave & & & \\
\hline CEIBA College Preparatory & & & & \\
\hline Academy & 280 Main St & Feet Depth & High & \\
\hline Watsonville/Aptos Adult Ed & & Feet Depth & & \\
\hline
\end{tabular}


APPENDIX D

PLAN REVIEW TOOL 


\section{APPENDIX A: \\ LOCAL MITIGATION PLAN REVIEW TOOL}

The Local Mitigation Plan Review Tool demonstrates how the Local Mitigation Plan meets the regulation in 44 CFR $\$ 201.6$ and offers States and FEMA Mitigation Planners an opportunity to provide feedback to the community.

- The Regulation Checklist provides a summary of FEMA's evaluation of whether the Plan has addressed all requirements.

- The Plan Assessment identifies the plan's strengths as well as documents areas for future improvement.

- The Multi-jurisdiction Summary Sheet is an optional worksheet that can be used to document how each jurisdiction met the requirements of the each Element of the Plan (Planning Process; Hazard Identification and Risk Assessment; Mitigation Strategy; Plan Review, Evaluation, and Implementation; and Plan Adoption).

The FEMA Mitigation Planner must reference this Local Mitigation Plan Review Guide when completing the Local Mitigation Plan Review Tool.

\begin{tabular}{|c|c|c|}
\hline $\begin{array}{l}\text { Jurisdiction: } \\
\text { City of Watsonville }\end{array}$ & $\begin{array}{l}\text { Title of Plan: } \\
\text { Local Hazard Mitigation Plan }\end{array}$ & $\begin{array}{l}\text { Date of Plan: } \\
\text { Currently of June } 82012\end{array}$ \\
\hline Local Point of Contact: & \multirow[t]{3}{*}{ Address: } & \\
\hline Title: & & \\
\hline Agency: & & \\
\hline Phone Number: & E-Mail: & \\
\hline
\end{tabular}

\begin{tabular}{|l|l|l|}
\hline State Reviewer: & Title: & Date: \\
\hline
\end{tabular}

\begin{tabular}{|l|l|l|}
\hline FEMA Reviewer: & Title: & Date: \\
\hline Date Received in FEMA Region (insert \#) & & \\
\hline Plan Not Approved & & \\
\hline Plan Approvable Pending Adoption & & \\
\hline Plan Approved & \\
\hline
\end{tabular}




\section{SECTION 1:}

\section{REGULATION CHECKLIST}

INSTRUCTIONS: The Regulation Checklist must be completed by FEMA. The purpose of the Checklist is to identify the location of relevant or applicable content in the Plan by Element/sub-element and to determine if each requirement has been 'Met' or 'Not Met.' The 'Required Revisions' summary at the bottom of each Element must be completed by FEMA to provide a clear explanation of the revisions that are required for plan approval. Required revisions must be explained for each plan sub-element that is 'Not Met.' Subelements should be referenced in each summary by using the appropriate numbers (A1, B3, etc.), where applicable. Requirements for each Element and sub-element are described in detail in this Plan Review Guide in Section 4, Regulation Checklist.

\section{REGULATION CHECKLIST Location in Plan (section and/or Regulation (44 CFR 201.6 Local Mitigation Plans) page number) \\ ELEMENT A. PLANNING PROCESS}

A1. Does the Plan document the planning process, including how it was prepared and who was involved in the process for each jurisdiction? (Requirement §201.6(c)(1))

A2. Does the Plan document an opportunity for neighboring communities, local and regional agencies involved in hazard mitigation activities, agencies that have the authority to regulate development as well as other interests to be involved in the planning process? (Requirement $\S 201.6(b)(2)$ )

A3. Does the Plan document how the public was involved in the planning process during the drafting stage? (Requirement $\S 201.6(\mathrm{~b})(1))$

A4. Does the Plan describe the review and incorporation of existing plans, studies, reports, and technical information? (Requirement $\S 201.6(\mathrm{~b})(3))$

A5. Is there discussion of how the community(ies) will continue public participation in the plan maintenance process? (Requirement $\S 201.6(\mathrm{c})(4)(\mathrm{iii}))$

A6. Is there a description of the method and schedule for keeping the plan current (monitoring, evaluating and updating the mitigation plan within a 5-year cycle)? (Requirement §201.6(c)(4)(i))

\begin{tabular}{|l|l|l|}
\hline Section 2.1 & & \\
\hline $\begin{array}{l}\text { Section 2.1, } \\
\text { Additional } \\
\text { Information Pending } \\
\text { City Action }\end{array}$ & & \\
\hline $\begin{array}{l}\text { Section 2.2,Additional } \\
\text { Information Pending City } \\
\text { Action }\end{array}$ & & \\
\hline $\begin{array}{l}\text { Section 4.2, 4.3, } \\
4.4\end{array}$ & & \\
\hline Pending EL Action & & \\
\hline $\begin{array}{l}\text { Pending EL } \\
\text { Action }\end{array}$ & & \\
\hline
\end{tabular}

\section{ELEMENT A: REQUIRED REVISIONS}




\section{REGULATION CHECKLIST}

\section{ELEMENT B. HAZARD IDENTIFICATION AND RISK ASSESSMENT}

B1. Does the Plan include a description of the type, location, and extent of all natural hazards that can affect each jurisdiction(s)? (Requirement §201.6(c)(2)(i))

B2. Does the Plan include information on previous occurrences of hazard events and on the probability of future hazard events for each jurisdiction? (Requirement §201.6(c)(2)(i))

B3. Is there a description of each identified hazard's impact on the community as well as an overall summary of the community's vulnerability for each jurisdiction? (Requirement §201.6(c)(2)(ii))

B4. Does the Plan address NFIP insured structures within the jurisdiction that have been repetitively damaged by floods? (Requirement §201.6(c)(2)(ii))

\section{ELEMENT B: REQUIRED REVISIONS}

Section 3.3 through 3.21, Subsections A, B

Section 3.3 through 3.21, Subsections C, D Section 3.3 through 3.21 , Subsections F, G, H

Section 3.5, Subsection C, Pending City and EL Action

\section{ELEMENT C. MITIGATION STRATEGY}

C1. Does the plan document each jurisdiction's existing authorities, policies, programs and resources and its ability to expand on and improve these existing policies and programs? (Requirement $\S 201.6(\mathrm{c})(3))$

C2. Does the Plan address each jurisdiction's participation in the NFIP and continued compliance with NFIP requirements, as appropriate? (Requirement §201.6(c)(3)(ii))

C3. Does the Plan include goals to reduce/avoid long-term vulnerabilities to the identified hazards? (Requirement $\S 201.6(\mathrm{c})(3)(\mathrm{i}))$

C4. Does the Plan identify and analyze a comprehensive range of specific mitigation actions and projects for each jurisdiction being considered to reduce the effects of hazards, with emphasis on new and existing buildings and infrastructure? (Requirement $\S 201.6(\mathrm{c})(3)(\mathrm{ii}))$ C5. Does the Plan contain an action plan that describes how the actions identified will be prioritized (including cost benefit review), implemented, and administered by each jurisdiction? (Requirement $\S 201.6(\mathrm{c})(3)(\mathrm{iv})$ ); (Requirement §201.6(c)(3)(iii))

C6. Does the Plan describe a process by which local governments will integrate the requirements of the mitigation plan into other planning mechanisms, such as comprehensive or capital improvement plans, when appropriate? (Requirement §201.6(c)(4)(ii))

\section{ELEMENT C: REQUIRED REVISIONS}




\section{REGULATION CHECKLIST Location in Plan

ELEMENT D. PLAN REVIEW, EVALUATION, AND IMPLEMENTATION (applicable to plan updates only)

D1. Was the plan revised to reflect changes in development?

(Requirement §201.6(d)(3))

D2. Was the plan revised to reflect progress in local mitigation efforts? (Requirement §201.6(d)(3))

D3. Was the plan revised to reflect changes in priorities?

(Requirement §201.6(d)(3))

ELEMENT D: REQUIRED REVISIONS

\section{ELEMENT E. PLAN ADOPTION}

E1. Does the Plan include documentation that the plan has been formally adopted by the governing body of the jurisdiction requesting approval? (Requirement §201.6(c)(5))

E2. For multi-jurisdictional plans, has each jurisdiction requesting approval of the plan documented formal plan adoption?

(Requirement §201.6(c)(5))

ELEMENT E: REQUIRED REVISIONS

\begin{tabular}{|l|l|l|}
\hline $\begin{array}{l}\text { Pending City } \\
\text { Action }\end{array}$ & & \\
\hline NA & & \\
\hline
\end{tabular}

\begin{tabular}{|l|l|l|}
\hline NA & & \\
\hline NA & & \\
\hline NA & & \\
\hline
\end{tabular}

ELMENTE:REQUIREDREVISIONS

ELEMENT F. ADDITIONAL STATE REQUIREMENTS (OPTIONAL FOR STATE REVIEWERS ONLY; NOT TO BE COMPLETED BY FEMA)

\begin{tabular}{|l|l|l|l|}
\hline F1. & & & \\
\hline F2. & & & \\
\hline ELEMENT F: REQUIRED REVISIONS & \\
\hline d
\end{tabular}




\section{REFERENCES}

Action Pajaro Valley, (2012).Pajaro Valley Watershed Information Center. Retrieved from http://www.pajarowatershed.org/

AMBAG, (1995).Water Resources Management Plan for Watsonville Slough System.

California Emergency Management Agency, (2009).Tsunami Inundation Map For Emergency Planning: Watsonville West Quadrangle.

California Emergency Management Agency, (2010).State of California Multi-Hazard Mitigation Plan

California Emergency Management Agency, (2012).Hazardous Materials Spill Reports. Retrieved from http://w3.calema.ca.gov/operational/malhaz.nsf/f1841a103c102734882563e200760c4a?SearchVi ew

City of Santa Cruz, (2007).Local Hazard Mitigation Plan 2007-2012.

City of Santa Cruz, (2011).Climate Adaptation Plan 2012-2017.

City of Watsonville, (1990).Hazard Mitigation Plan.

City of Watsonville, (2006).Emergency Operation Plan.

City of Watsonville.(2006). General Plan, Watsonville Vista 2030.

City of Watsonville, (2010a).Urban Water Management Plan.

City of Watsonville, (2010).Stormwater Management Plan 2009-2010.

City of Watsonville, (2011).Capital Improvement Program Multi-Year Plan (201-2016). 
City of Watsonville, (2012a).GIS Data.

City of Watsonville, (2012b). City Website, Retrieved from http://www.ci.watsonville.ca.us/

City of Watsonville, (2012).Municipal Code.

City of Watsonville, (2012).Unreinforced Masonry Buildings List.

County of Santa Barbara, (2004).Local Hazard Mitigation Plan.

County of Santa Clara, Public Review Draft.(2011). Local Hazard Mitigation Plan.

County of Santa Cruz, (2002).Santa Cruz County Flood Hazard Mitigation Plan.

County of Santa Cruz, (2003).Watsonville Slough Resource Conservation Enhancement Plan

County of Santa Cruz, (2010).Local Hazard Mitigation Plan 2010-2015.

County of Santa Cruz, County of Monterey, U.S. Army Corps of Engineers, (2011).Pajaro River Project Draft EIR EIS. Retrieved from http://www.ebidboard.com/docs/1202/090052/Pajaro\%20River\%20Project\%20scrb\%20sm.pdf

FEMA, (2006).Santa Cruz County Flood Insurance Study.

FEMA, (2012).Flood Hazard Mapping.

National Flood Insurance Program, Community Service Rating System, (2011). CRS Communities. Retrieved fromhttp://www.fema.gov/business/nfip/crs.shtm

National Flood Insurance Program, (2011).Loss Statistics. Retrieved from http://bsa.nfipstat.com/reports/1040.htm

National Oceanic and Atmospheric Administration Satellite and Information Service, (2012). Query Results. Retrieved from http://www4.ncdc.noaa.gov/cgi-win/wwcgi.dll?wwevent $\sim$ storms 
National Oceanic and Atmospheric Administration, (2012).Volcanoes. Retrieved from http://www.noaawatch.gov/themes/volcanoes.php

National Transportation Safety Board Accident Database \& Synopses.(2012). Database Query Results. Retrieved from http://www.ntsb.gov/aviationquery/index.aspx

Pacific Gas and Electric Company, (2012).Gas Transmission Pipeline System Map. http://www.pge.com/myhome/edusafety/systemworks/gas/transmissionpipelines/

San Benito County Water District, Pajaro Valley Water Management Agency, Santa Clara Valley Water District, (2007). Pajaro River Watershed Integrated Regional Water Management Plan.

Santa Clara Valley Water District, (2012). Chesbro Dam and Reservoir. Retrieved from http://www.valleywater.org/Services/ChesbroDamAndReservoir.aspx

Schwab et al. (1998).Planning for Post-Disaster Recovery and Reconstruction.PAS 483/484, FEMA-

APA.

United States Natural Resources Conservation Service, (2012).Web Soil Survey. Retrieved from

U.S. Census Bureau, (2010a).Age Groups and Sex: 2010. 2010 Census Summary File 1

U.S. Census Bureau, (2010b).Disability Characteristics.2008-2010 American Community Survey 3Year Estimates.

U.S. Census Bureau, (2010c).Selected Economic Characteristics.2008-2010 American Community Survey 3-Year Estimates.

U.S. Census Bureau, (2010d).Profile of General Population and Housing Characteristics: 2010. 2010 Demographic Profile Data. 
U.S. Census Bureau, (2010e).Selected Housing Characteristics. 2006-2010 American Community Survey 5-Year Estimates.

U.S. Census Bureau, (2010f).Selected Social Characteristics in the United States. 2006-2010 American Community Survey 5-Year Estimates.

U.S. Department of Transportation Pipeline and Hazardous Materials Safety Administration, (2011). Safety-Related Condition Reports. Retrieved from http://www.phmsa.dot.gov/portal/site/PHMSA/menuitem.ebdc7a8a7e39f2e55cf2031050248a0c/? vgnextoid=4bde326d1104b210VgnVCM1000001ecb7898RCRD\&vgnextchannel=3430fb649a2d c110VgnVCM1000009ed07898RCRD\&vgnextfmt=print.

Watsonville Municipal Airport, (2001).Airport Master Plan 2001-2020. 